ENSAYO

\title{
LA PENA COMO RETRIBUCIÓN
}

\author{
Juan Pablo Mañalich R.
}

La tesis de que la justificación de (la imposición de) la pena sólo puede descansar en un principio de prevención constituye — se sostiene en estas páginas - un auténtico lugar común del discurso de la teoría penal contemporánea. La tesis alternativa, esto es, la justificación retribucionista de la pena, suele ser considerada incompatible con una definición secular del ejercicio de la potestad punitiva del Estado. El propósito de este trabajo es proveer una defensa para una concepción retribucionista de la pena. En la primera parte se argumenta a favor de ella subrayando la incompatibilidad entre una justificación utlilitarista de la pena y la exigencia de culpabilidad del sancionado. En la segunda parte del trabajo se argumenta a partir de una indagación sobre las implicaciones que tiene la fundamentación retribucionista para el desarrollo de una teoría general del derecho penal. Como argumento decisivo a favor de la concepción retribucionista se destaca su ajuste a una serie de características que tradicionalmente se asocian a la imagen de un ejercicio legítimo de la

Juan Pablo Mañalich. Licenciado en Ciencias Jurídicas y Sociales, Universidad de Chile. Becario del DAAD en el programa de doctorado en derecho de la Universidad de Bonn, Alemania. El autor se ha desempeñado previamente como ayudante y profesor invitado en el Departamento de Ciencias Penales de la Universidad de Chile, como profesor de la Facultad de Derecho de la Universidad Adolfo Ibáñez y como profesor visitante de derecho penal y teoría del derecho en la Universidad de Puerto Rico.

Estudios Públicos, 108 (primavera 2007). 
potestad punitiva del Estado. El artículo concluye con la tesis de que una asunción radical de las implicaciones institucionales del derecho penal retributivo encierra el reconocimiento de un profundo potencial crítico respecto al funcionamiento de los sistemas penales contemporáneos, incluido el chileno.

\section{LA RETRIBUCIÓN COMO TEORÍA DE LA PENA}

\section{I.1. La tensión entre estructura y función}

Pa arece poco controversial la afirmación de que, en una medida importante, la pregunta por la definición más general del derecho penal no puede responderse sino por la vía de una respuesta a la pregunta por la definición de la pena. Esta constatación no supone, empero, una determinación del punto de vista desde el cual esa respuesta puede ser elaborada. A este respecto, la disyuntiva se plantea entre la adopción de una perspectiva estructural y la adopción de una perspectiva funcional. Esto significa que la cuestión de la definición de la pena, y consiguientemente, del derecho penal, puede presentarse como una cuestión de estructura o una cuestión de función.

El desarrollo de esta consideración puede emprenderse a partir de la sugerencia, hecha por Michael S. Moore, de que en la reflexión acerca de la diferenciación de áreas del derecho los problemas que han de ser analizados son, fundamentalmente, dos: en primer lugar, un problema propiamente ontológico, constituido por la pregunta acerca de qué clase de cosa es una determinada área del derecho; y en segundo lugar, un problema de individuación, en el sentido de la pregunta acerca de los criterios bajo los cuales es posible identificar a un área del derecho frente a otras ${ }^{1}$. Como el propio Moore lo muestra, es crucial advertir la relación existente entre ambos problemas: la determinación de los criterios de individuación de un área del derecho es dependiente de la determinación de los criterios que definen qué cuenta como un área del derecho².

Según Moore, la solución del problema ontológico puede obtenerse a partir de la observación de que en general puede reconocerse tres clases

\footnotetext{
${ }^{1}$ Moore, Michael: Placing Blame, 1997, p. 19.

2 Ibídem, p. 22.
} 
de clases de cosas, a saber, clases naturales, clases nominales y clases funcionales ${ }^{3}$. Lo que es propio de una clase natural es que las cosas de esa clase comparten una naturaleza que determina lo que son. Esta naturaleza es típicamente una cierta composición estructural: así por ejemplo, de acuerdo con la mejor teoría disponible, que algo pertenezca a la clase "oro" se sigue de que el objeto presente cierta composición atómica. Frente a las clases naturales, una clase es nominal en tanto lo que agrupa a los miembros de la clase no es más que un nombre usado para hacer referencia a las instancias de esa clase, la cual, de este modo, es convencionalmente constituida. Por último, una clase es funcional en la medida en que sus instancias sí comparten, a diferencia de las instancias de una clase nominal, una naturaleza común, pero ésta, a diferencia de lo que corresponde a las clases naturales, no está determinada por una cierta propiedad estructural, sino por el desempeño de una función.

Lo importante es la posibilidad de reconocer la existencia de un área del derecho concibiéndola como una clase de determinada clase. Así, puede haber ciertas áreas del derecho que preferentemente admitan ser entendidas como clases funcionales, en el sentido de que lo que las distingue es la realización de una determinada función: por ejemplo, identificando el área del derecho de la responsabilidad civil extra-contractual en atención al desempeño de una función de justicia correctiva ${ }^{4}$. En la determinación de otras áreas del derecho, en cambio, lo decisivo parece ser el uso arbitrario de una etiqueta para definir su alcance. Según Moore, éste sería el caso del derecho administrativo en la cultura jurídica angloamericana ${ }^{5}$. Finalmente, también sería posible identificar algunas áreas del derecho recurriendo a un criterio estructural, por ejemplo, atendiendo a la disponibilidad de alguna forma de consecuencia jurídica o de medida jurídica determinada, por ejemplo, de sanciones coercitivas. Esto último supondría determinar esa área del derecho en cuestión como una clase (cuasi-)natural, esto es, definida por cierta estructura común a sus instancias ${ }^{6}$.

En relación con la determinación de la clase “derecho penal”, Moore da cuenta de que en principio sería plausible postular su categorización

${ }^{3}$ Ibídem, pp. 19-20.

${ }^{4}$ Ibídem, p. 20.

${ }^{5}$ Ibídem, p. 21. La calificación es importante, porque Moore no pretende embarcarse en un proyecto de general jurisprudence, sino sólo de particular jurisprudence, esto es, de teoría jurídica referida al derecho de un determinado sistema o cultura jurídica (ibídem, pp. 18-19).

${ }^{6}$ Ibídem, p. 21. 
como una clase de cualquiera de las tres clases. Concebir el derecho penal como una clase (meramente) nominal implicaría entender que aquello que cuenta como esa área del derecho depende exclusivamente de una convención lingüística ${ }^{7}$. Mucho más generalizada, sin embargo, se encontraría una concepción del derecho penal como una clase (cuasi-)natural, esto es, definida por una cierta propiedad estructural, a saber, la disponibilidad de una forma determinada de sanción, que típicamente consiste en la privación o afectación de algunos bienes personales fundamentales (vida, la libertad ambulatoria, etc. $)^{8}$. Lo crucial es advertir que, sobre esta base, la determinación de la función del derecho penal aparece como dependiente de la identificación de una característica estructural: sólo después de que la determinación de qué cuenta como derecho penal ha tenido lugar apuntando a una forma paradigmática de consecuencia jurídica (la sanción coercitiva consistente en la privación de determinados bienes personales), se plantea la pregunta por la función que esa área del derecho, así configurada, puede desempeñar. La respuesta, según Moore, tiende a consistir entonces en una conjunción de funciones de prevención, justicia retributiva (y eventualmente, también de justicia distributiva) $)^{9}$.

La objeción primordial a que se enfrenta una concepción del derecho penal centrada en esa característica estructural consiste en lo poco inteligible que resulta la pregunta acerca de qué cuenta como pena si no se presupone una respuesta previa a la pregunta de por qué se imponen penas. ¿Cómo diferenciar el cobro de un impuesto de la imposición de una multa si no es atendiendo al propósito punitivo de ésta que no se da en aquél? Si esa consideración estructural presupone una toma de posición (previa) acerca de la función desempeñada por el área del derecho así identificada, ésta resulta ser, en definitiva, una clase funcional ${ }^{10}$. Lo que entonces se plantea es la determinación de la función cuyo desempeño hace posible establecer qué cuenta como (parte del) derecho penal.

${ }^{7}$ Ibídem, p. 23. Es obvio que, en todo caso, el uso de la expresión “derecho penal” para designar esa área del derecho descansa en una convención lingüística. La tesis de la clase nominal, empero, supone un convencionalismo no sólo referido a la selección de esa expresión, sino también a la determinación de la extensión del objeto por ella designado.

${ }^{8}$ Ibídem.

${ }^{9}$ Ibídem, p. 24.

${ }^{10}$ Ibídem, p. 25. 


\section{I.2. Definición de "pena” versus justificación de la pena}

Determinar la función que cabe atribuir a la sanción penal es el objeto de disputa tradicional entre las diferentes teorías de la justificación de la pena. En esta discusión, empero, no es posible prescindir completamente de algunas características estructurales que parecen asociadas, al menos en un estadio de precomprensión, a la noción de pena. De este modo, la discusión ha de entenderse sujeta a un constreñimiento de equilibrio reflexivo, en el sentido de que en cierto punto ha de ser posible que el objeto de atribución funcional, a pesar de su denominación, ya no cuente como pena ${ }^{11}$. Como se verá, esto último puede constituirse en un punto de apoyo importante para una teoría retribucionista.

\section{a) ¿Neutralidad de la definición?}

Al efecto, considérese la definición estipulativa de "pena" ofrecida por Kindhäuser: por "pena" habría que entender "la irrogación de un mal como expresión de desaprobación por un comportamiento previo defectuoso"12. El problema de este planteamiento radica en que el mismo parece conllevar una concepción del derecho penal como clase nominal. Si esta definición del término "pena" no resultara satisfecha por una determinada consecuencia jurídica fijada en una norma de sanción, entonces ésta no podría constituir una pena, independientemente de la función que pudiera atribuírsele. Un planteamiento tal se encontraría expuesto a la objeción de representar lo que Hart llamó un definitional stop en la discusión acerca de los propósitos que guían el ejercicio de la práctica punitiva ${ }^{13}$. Partir de una definición de "pena", tal que necesariamente resultan excluidas por ella una o más teorías que pretenden ser teorías de la pena no constituiría más que una gran petición de principio.

La objeción resulta concluyente en tanto la definición de "pena" se presente como una determinación del significado de la palabra "pena". Pero es posible sugerir una comprensión distinta del sentido de esa definición. Ésta puede entenderse no como la demarcación de las propiedades semánti-

\footnotetext{
${ }^{11}$ Para esta noción de equilibrio reflexivo, Rawls, John: A Theory of Justice, 1971, pp. 46-53.

12 Kindhäuser, Urs: "Personalität, Schuld und Vergeltung”, 1989, p. 493. El mismo planteamiento se encuentra en Kindhäuser, Urs: Gefährdung als Straftat, 1989, pp. 153-160.

${ }^{13}$ Hart, H.L.A.: "Prolegomenon to the Principles of Punishment", 1968, p. 5. Sobre esto también Pawlik, Michael: Person, Subjekt, Bürger, 2004, pp. 16-17.
} 
cas del término "pena” (al modo, por ejemplo, del positivismo lógico, en el sentido de una identificación del conjunto de condiciones necesarias y suficientes para que algo sea denotado por ese término), sino como una determinación preliminar de los elementos que intuitivamente, en un estadio prerreflexivo, parecen estar asociados a la institución de la pena, de modo tal que esta determinación preliminar pueda ser eventualmente refutada por una definición post-reflexiva. Si alguna teoría de la pena resulta descartada por esa definición, la cuestión a resolver es si, en un ejercicio de equilibrio reflexivo, es posible modificar o suprimir la cláusula de la definición que resulta incompatible con la teoría en cuestión sin que se venga abajo nuestra precomprensión mínima acerca de lo que cuenta como una pena. La estrategia argumentativa a seguir, por ende, tiene que ser propiamente holista: la definición de pena ha de resultar coherente con un conjunto amplio de proposiciones (tenidas justificadamente por) verdaderas acerca de la configuración de la práctica punitiva.

\section{b) Implicaciones sustantivas de la definición}

La definición ofrecida por Kindhäuser admite ser descompuesta en tres elementos: la pena sería (1) la irrogación coercitiva de un mal (2) que expresa desaprobación (3) por una conducta previa defectuosa. Cualquier teoría de la justificación de la pena, ya sea una teoría retribucionista o una teoría prevencionista, ya sea una teoría de la prevención especial o una teoría de la prevención general, parece resistir el enfrentamiento al primer elemento de la definición: para cualquiera de estas teorías, la pena presenta la propiedad de consistir en la irrogación de un mal para quien sufre su imposición. Esto se explica por cuanto, en el marco de esa definición, este elemento contiene la referencia a una característica primariamente estructural, y no funcional, de lo que cabe entender por "pena"; la irrogación de un mal se corresponde con la particular forma de consecuencia jurídica que tradicionalmente se entiende como pena. El segundo y el tercer elemento, en cambio, contienen referencias a propiedades que, de atribuirse en definitiva a la institución de la pena, necesariamente restringen el abanico de funciones susceptibles de ser atribuidas a ella. Que el sentido de la irrogación del mal sea la expresión de desaprobación, y que el objeto de la desaprobación sea un comportamiento (previo) defectuoso, parecen volver imposible que una teoría puramente prevencionista pueda servir para justificar la institución de la pena así definida, lo cual, empero, de acuerdo a la objeción del definitional stop, podría resultar desfavorable para la definición en cuestión. Resolver esto último, sin embargo, requiere algunas precisiones ulteriores. 
Tras ofrecer la definición ya consignada, Kindhäuser propone y desarrolla algunos criterios de legitimación de la pena que harían inviable una teoría de la prevención especial. La premisa está constituida por la proposición de que la legitimidad de la pena, que es la consecuencia jurídica establecida en una norma de sanción, en todo caso presupone la legitimidad de la norma de comportamiento reforzada mediante esa norma de sanción ${ }^{14}$. Piénsese, por ejemplo, en la prohibición, dirigida a todo sujeto, de matar a otro ser humano (nacido) como la norma de comportamiento en cuestión, y en la habilitación, dirigida al juez, de la imposición de una determinada pena de privación de libertad como consecuencia de la comisión de un homicidio como la correspondiente norma de sanción. Lo que legitima a una norma de comportamiento, cuyo quebrantamiento constituye el antecedente de aplicación de la respectiva norma de sanción, es la protección de un bien jurídico, entendido como la característica de un ser humano, de una cosa o de una institución que es merecedora de protección bajo un principio de coexistencia de libertad ventajosa para todos ${ }^{15}$.

Aquí no interesa considerar (todavía) las implicaciones de este criterio de legitimación de las normas de comportamiento reforzadas punitivamente, sino sólo indagar en la relación entre la legitimidad de la norma de comportamiento y la norma de sanción correspondiente, que es aquella norma que confiere la habilitación para imponer la sanción por la realización imputable de una conducta prohibida por la norma de comportamiento. La razón por la cual se hace necesario el reforzamiento de (algunas) normas de comportamientos con normas de sanción radica, según Kindhäuser, en la inestabilidad del seguimiento de aquéllas: Puede ser individualmente ventajoso el quebrantamiento de una norma cuya observancia generalizada es ventajosa para todos; pero si cada uno de los destinatarios de la norma la quebranta, desaparece la ventaja que para todos tiene el hecho de que la norma sea observada, de modo que la situación resultante es peor que aquella en la cual la norma es observada por todos ${ }^{16}$. Dada esta falta de seguridad que cada destinatario de la norma puede tener acerca del seguimiento de la norma por parte de los demás, el reforzamiento de la norma mediante una norma de sanción desempeñaría la función de imponer su reconocimiento como vinculante, lo cual en principio resulta legítimo, en tanto aceptable para todos ${ }^{17}$.

\footnotetext{
${ }^{14}$ Kindhäuser, Urs: "Personalität, Schuld und Vergeltung”, 1989, p. 494.

${ }^{15}$ Ibídem, p. 496.

${ }^{16}$ Ibídem.

${ }^{17}$ Ibídem, p. 497.
} 
Sobre esta base, Kindhäuser mantiene que una teoría de la prevención especial, en términos de re-socialización, ha de resultar excluida del catálogo de propuestas justificadoras plausibles. Esto, porque en la medida en que para todo sujeto puede resultar individualmente ventajoso el quebrantamiento de la norma de comportamiento, la evitación de éste no puede constituir un fin educativo específicamente referido al autor del delito, pues entonces éste sólo ha actuado como cualquier agente estratégicamente racional actuaría ${ }^{18}$.

Lo que aquí interesa, sin embargo, es mostrar que la clase de teoría que Kindhäuser de este modo descarta no es, en sus propios términos, una teoría puramente preventivo-especial. Pues la teoría a que Kindhäuser hace referencia es una teoría que sí resiste la definición de pena por él propuesta, aunque no es congruente con una de las razones que justificarían el reforzamiento punitivo de normas de comportamiento. En otras palabras, la teoría preventivo-especial que Kindhäuser critica es una teoría de la prevención especial que no pone en cuestión su estipulación sobre el significado de "pena”, o sea, una teoría que, prima facie, resulta compatible con que la imposición de la pena exprese desaprobación por un comportamiento previo defectuoso. Una teoría tal es una teoría que parece compatible con la exigencia de culpabilidad como condición de la pena, esto es, que puede reconocer el principio de culpabilidad como un límite que ha de observarse al momento de la imposición de la pena. Una teoría que, por el contrario, ofreciera una justificación preventivo-especial de la pena no sujeta al constreñimiento del principio de culpabilidad no sería una teoría de la justificación de la "pena”, tal como ésta ha sido definida por Kindhäuser.

Algo similar cabe decir respecto de la observación de Kindhäuser acerca de la objeción tradicionalmente dirigida a la teoría de la prevención general negativa, que entiende la conminación legal de la imposición de la pena como una amenaza condicional dirigida a motivar a evitar la comisión de un delito por temor a la sanción posterior. La objeción tradicional en contra de esta concepción se encuentra en que ella no excluiría la posibilidad de que la imposición de la pena recaiga sobre un sujeto no culpable. Kindhäuser afirma que una objeción tal es incorrecta, puesto que de lo que aquí se trata es, en todo caso, de una teoría (de la justificación) de la pena, cuya imposición está condicionada, según la definición preliminar, por la verificación de un comportamiento previo defectuoso ${ }^{19}$. Si se trata de una

\footnotetext{
${ }^{18}$ Ibídem.

${ }^{19}$ Ibídem, p. 498.
} 
teoría de justificación de la pena, tal como ésta ha sido definida por estipulación, la teoría de la prevención general ha de ser una teoría que respete el límite constituido por la exigencia de culpabilidad del sancionado ${ }^{20}$.

Es notable la pertinencia de la advertencia acerca del definitional stop a este respecto. Hart da cuenta de que un abuso de la definición del término "pena" (punishment) típicamente se encuentra, precisamente, en algunas respuestas a la objeción de que una teoría puramente prevencionista no excluiría la posibilidad de que pueda imponerse una pena a un sujeto no culpable; la respuesta consistiría en que la teoría prevencionista que afirmara la imposición de la pena a un no-culpable ya no sería una teoría de la justificación de la pena ${ }^{21}$. Según Hart, esta respuesta no sólo dejaría insatisfecho al objetor retribucionista, sino que sobre todo deja oculta la cuestión cuyo análisis resulta más importante, a saber, la cuestión del estatus racional y moral de nuestra preferencia por un sistema punitivo bajo el cual la imposición de medidas coercitivas sólo tenga lugar respecto de individuos responsables por la comisión de un delito ${ }^{22}$.

La tesis de que una teoría ha de necesariamente respetar la exigencia de culpabilidad como condición de la imposición de la pena para ser una teoría de la "pena" se ve expuesta, por ende, a la objeción del definitional stop. Para salvar esta objeción, lo que hay desarrollar es la tesis de que la definición del término "pena” ofrecida por Kindhäuser presupone una teoría de la justificación de la pena, y que ésta es la teoría correcta. La definición que resulta incompatible con una teoría que niegue la exigencia de culpabilidad como condición de la imposición de la pena es correcta, pero no porque el debate acerca de la mejor definición del término "pena" haya concluido con la enunciación de esa definición, sino porque esa definición es el producto de la teoría correcta acerca de la justificación de la institución de la pena.

${ }^{20}$ La razón principal por la cual, de acuerdo con Kindhäuser, una teoría de la prevención general negativa ha de ser rechazada es que la orientación de la conminación y la imposición de la pena a la intimidación puede desconocer la relación interna que debe mantenerse entre la medida de la pena y el peso de la norma quebrantada, además de que ella difícilmente puede dar cuenta del sentido reprobatorio que se atribuye a la pena (ibídem, pp. 498-499).

${ }^{21}$ Hart, H.L.A.: "Prolegomenon to the Principles of Punishment”, 1968, pp. 56.

${ }^{22}$ Ibídem. 


\section{c) El mapa del problema}

Las consideraciones anteriores hacen posible organizar la discusión del siguiente modo ${ }^{23}$. En términos generales, el debate acerca de la justificación de la pena tiene lugar en un espacio dominado por dos principios de justificación alternativos: el de prevención y el de retribución. Una primera distinción que cabe trazar entre las distintas teorías de la justificación de la pena atiende a si uno de estos principios es defendido como el único principio de justificación de la pena, o si en cambio se defiende alguna combinación de ambos. De ahí que puedan diferenciarse teorías monistas y teorías pluralistas de la justificación de la pena. Al interior del conjunto de teorías monistas, es posible diferenciar, propiamente, teorías retribucionistas y teorías prevencionistas, según si la imposición de la pena es justificada en términos retrospectivos, entendiendo que la pena es una reacción en sí misma correcta y justa frente al comportamiento previo defectuoso (retribución), o bien en términos prospectivos, atendiendo a la evitación de la comisión de delitos futuros (prevención). Al interior del conjunto de teorías pluralistas, por otra parte, es posible diferenciar teorías que mantienen que el principio que justifica la imposición de la pena es uno de prevención, el cual resulta limitado por el principio de retribución, frente a teorías que mantienen que la relación es la inversa, o sea, que el principio justificador es el de retribución, mientras que el principio limitador es el de prevención. De acuerdo con la primera variante de teoría pluralista o combinatoria, la pena habría de imponerse en virtud de sus consecuencias preventivas favorables, siempre que ello respete la exigencia de culpabilidad del sujeto sancionado; de acuerdo con la segunda variante, en cambio, la pena habría de imponerse en virtud de su prestación retributiva, siempre que ella también resulte preventivamente indicada. Como Moore lo reconoce, hay un sentido importante en que ambas variantes de teoría pluralista o mixta pueden ser reducidas a una sola: frente a la pregunta de si debe imponerse sanción penal a una persona, una y otra teoría proponen el mismo tratamiento para todos los casos, de modo que lo que las diferenciaría sería la motivación subyacente a la defensa de una y otra ${ }^{24}$.

A continuación se presentará el argumento de que las teorías monistas de la prevención especial y de la prevención general son incorrectas, lo cual habla a favor de una definición de "pena" como la de Kindhäuser, que las hace inviables. Sólo después se indagará en las implicaciones de esta

${ }^{23}$ Para lo que sigue, con algunos matices, Moore, Michael: Placing Blame, 1997, pp. 91-94.

${ }^{24}$ Ibídem, p. 94. 
definición que tendrían que llevar a defender una versión de teoría monista de la retribución frente a los intentos de combinación de criterios preventivos y retributivos que se encuentran en las teorías pluralistas.

\section{I.3. La justificación prevencionista de la pena}

\section{a) ¿Se puede castigar a un inocente?}

En términos generales, toda teoría prevencionista de la pena ofrece una justificación de ésta que descansa en una moral utilitarista: la imposición de la pena se justifica si y sólo si el mal constituido por la imposición de la pena es sobrepasado, en términos agregados, por el bien de la prevención de la comisión de delitos futuros, ya sea por el propio individuo penado, en el sentido de una teoría de la prevención especial, ya sea por cualquier individuo, en el sentido de una teoría de la prevención general. Bajo el principio de utilidad, que define como moralmente correctas a aquellas acciones cuyas consecuencias producen un incremento neto de utilidad (más allá de cómo esto pueda determinarse), la decisión de imponer una sanción a un sujeto al cual no puede atribuirse la realización culpable de la conducta conminada con esa sanción se justificaría en tanto este costo individual resultara compensado por la obtención de mayor bienestar agregado. En principio, bajo la sola consideración del principio de utilidad, la imposición de la pena a un sujeto inocente puede considerarse una externalidad negativa de la decisión punitiva preventivamente justificada ${ }^{25}$.

Esta indagación en las consecuencias de una teoría puramente prevencionista de la pena suele ser resultar en una objeción a esa clase de teorías. La fuerza de la objeción se encuentra en la incompatibilidad de esa teoría con el juicio moral de que un individuo no puede sufrir la imposición de una sanción de la cual no es merecedor. La objeción puede presentarse, siguiendo a Moore, bajo la forma de un argumento de reducción al absur$\mathrm{do}^{26}$. La premisa mayor del argumento consiste en la proposición, definito-

${ }^{25}$ Uno de los pocos utilitaristas que ha estado dispuesto a abrazar dicha posibilidad es Smart (véase Smart, J.J.C.: “An Outline of a System of Utilitarian Ethics”, 1973, pp. 67-73). Según Moore, esto ha llevado a que en el glosario de términos construidos sobre la base de nombres de filósofos, elaborado por Daniel Dennett, el verbo "to outsmart” aparezca definido como "abrazar la conclusión del argumento de reductio ad absurdum del oponente”, así como en "pensaban que me tenían pero fui más listo que ellos [I outsmarted them]. Concedí que a veces es justo colgar a un hombre inocente” (Moore, Michael: Placing Blame, 1997, p. 95).

${ }^{26}$ Ibídem, pp. 94-95. 
ria de una teoría prevencionista de la pena, de que ésta ha de ser impuesta si y sólo si ello produce una ganancia social neta. La segunda premisa está constituida por la proposición de que en el caso particular la punición de un inocente produciría una ganancia social neta. La tercera premisa reproduce el juicio moral conflictivo, que señala que la pena no debería imponerse a un individuo que no es culpable. La conjunción de las tres premisas produciría, entonces, una conclusión contradictoria: la pena debería y no debería imponerse.

\section{b) Utilitarismo de la regla}

Moore reconoce tres posibilidades de evitar esta conclusión absurda. La primera sería renunciar a la premisa que expresa el juicio moral de que un inocente no puede ser sancionado. El carácter concluyente del juicio moral en contra, sin embargo, tendría que excluir la plausibilidad de esta posibilidad. La segunda posibilidad de defensa de una teoría utilitarista frente a la reductio parece mucho más plausible, y se corresponde con una apelación a la distinción entre dos formas de utilitarismo, a saber, un utilitarismo extremo o utilitarismo de la acción, por una parte, y un utilitarismo restringido o utilitarismo de la regla, por otra ${ }^{27}$. El argumento consiste en ofrecer una versión de la teoría utilitarista con arreglo a la cual el principio de utilidad pueda entenderse como el criterio de justificación de la práctica punitiva como tal, pero no como el criterio de justificación de una acción particular de punición efectuada en el marco de esa práctica.

La exposición más célebre de este argumento se encuentra en una temprana contribución de John Rawls ${ }^{28}$. Tras constatar que apenas se formula la pregunta acerca de la justificación de la pena aparecen dos concepciones contrapuestas, la retribucionista y la utilitarista, Rawls sugiere que uno y otro principio aparecen comprometidos en niveles distintos: mientras que el principio de utilidad es pertinente para la justificación de la práctica del castigo, el principio de retribución es pertinente para la justificación de actos particulares de punición efectuados al interior de esa práctica justificada de modo utilitarista ${ }^{29}$. La importancia de la tesis de Rawls, empero, radica en que ella no pretende defender alguna versión de teoría pluralista que combina dos principios contrapuestos, sino que mantiene que la perti-

${ }^{27}$ Véase Hoerster, Norbert: “Ética Utilitarista y Generalización”, 1975, pp. 50 ss. Acerca de la aplicación de esta distinción para el problema de la justificación de la pena, Baurmann, Michael: Zweckrationalität und Strafrecht, 1987, p. 202 ss.

${ }^{28}$ Rawls, John: “Two Concepts of Rules”, 1955, pp. 3 ss.

${ }^{29}$ Ibídem, pp. 5, 9-10. 
nencia de las exigencias retributivas al momento de la imposición de la pena en el caso particular resulta de la propia configuración de la práctica sobre la base del principio de utilidad, en la medida en que éste sea enunciado como referido a la justificación de una práctica que, por alguna razón, no reproduce esta justificación en cada una de sus operaciones. La razón por la cual las acciones particulares que caen bajo esa práctica no han de ser justificadas (directamente) por el principio que justifica la práctica sería el mismo principio de utilidad. De ahí que pueda hablarse de utilitarismo restringido: la aplicación del principio de utilidad es restringida por el propio principio de utilidad.

Así, una práctica punitiva institucionalizada que estuviese diseñada de modo tal que, al menos en determinadas circunstancias, los funcionarios que la administran tuvieran discreción para poder imponer penas a individuos que no son culpables, resultaría ser una práctica que difícilmente podría ser justificada por el principio de utilidad. Las personas expuestas a caer bajo la práctica tendrían buenas razones para temer ser punidas a pesar de no ser culpables de delito alguno, eventualmente desarrollarían un sentimiento compasivo hacia los individuos de hecho sancionados, etc. La institución no sería funcional a la consecución de un propósito preventivo ${ }^{30}$. Por eso, es razonable suponer que el principio de utilidad exige que la práctica sea diseñada de modo que sólo pueda imponerse pena a un culpable, sin que la decisión particular acerca de si un individuo ha de sufrir la imposición de la pena pueda resolverse, entonces, invocando directamente el principio de utilidad. Lo que esto muestra, tal como el propio Rawls lo enfatiza, es que la distinción entre la justificación de la práctica y la justificación de acciones particulares realizadas al interior de esa práctica presupone una concepción de las reglas que definen la forma de operar al interior de esa práctica como reglas constitutivas, esto es, como reglas que constituyen una forma de actividad (en este caso, la punición) que no puede tener lugar a menos que esas reglas sean seguidas ${ }^{31}$. El principio de utilidad determinaría cuáles son las reglas que constituyen la práctica; la regla de que sólo puede ser punido un culpable, entonces, sería una regla de la práctica justificada por el principio de utilidad.

${ }^{30}$ Ibídem, pp. 11-12. Un punto de vista similar se encuentra en Robinson, Paul y John Darley: “The Utility of Desert”, 1997 pp. 453 ss.; Robinson, Paul: “Why Does the Criminal Law Care What the Layperson Thinks is Just: Coercive versus Normative Crime Control”, 2000, pp. 1.839 ss.

${ }^{31}$ Rawls, John: “Two Concepts of Rules”, 1955, pp. 24-29. Sobre esta noción de reglas constitutivas, Searle, John: Speech Acts, 1969, pp. 33-42; Searle, John: The Construction of the Social Reality, 1995, pp. 43-51. 
Independientemente de sus méritos estéticos, esta defensa de una teoría utilitarista de la pena ha de enfrentar la objeción de que ella sólo desplaza el punto en el cual se presenta la incompatibilidad entre la primera y la tercera premisa del argumento de la reducción al absurdo. Así, suponiendo que haya algún riesgo de que la población detecte la punición de un inocente y, por ende, algún riesgo de desmoralización que deba ser internalizado en el balance de beneficios y costos totales, esto no obsta a que de hecho puedan presentarse casos en que la utilidad de la punición de un inocente de todas formas fuere positiva (esto es, descontando de los beneficios así conseguidos los costos de desmoralización, desconfianza, etc. $)^{32}$. Como Hart observa, negar en un caso tal la punición del inocente sería inconsistente con el principio de utilidad, de modo tal que si esa punición ha de rechazarse, ello sólo puede fundarse en un principio independiente ${ }^{33}$. $\mathrm{Si}$, en la terminología de Rawls, una de las reglas que define qué cuenta como operación de la práctica punitiva no puede mirarse, al menos no en todo caso, como una consecuencia del principio de utilidad, entonces debe admitirse la pertinencia de un criterio de justificación alternativo.

La única posibilidad remanente para evitar el absurdo de la conclusión consiste en abandonar el principio de utilidad como único criterio de justificación de la pena. O sea, habría que admitir que la justificación de la pena está condicionada por un principio que no es reducible al principio de utilidad, a saber, un principio de justificación retrospectiva. Que este criterio de justificación pueda ser definido propiamente como un principio de retribución, sin embargo, no es algo que pueda darse por sentado. Que la exigencia de culpabilidad conlleve una fundamentación retributiva de la justificación de la pena supone entender esa exigencia como una condición necesaria y suficiente para la imposición de la pena. Es el caso, no obstante, que las variantes más significativas de lo que puede considerarse una teoría pluralista o combinatoria de la justificación de la pena entienden que la exigencia de culpabilidad sólo designa una condición necesaria, pero no suficiente, para la imposición de la pena, pues ésta en todo caso requeriría la satisfacción de una exigencia de necesidad preventiva. Lo que es distintivo de una teoría retribucionista, por ende, es que en ella la culpabilidad desempeña una función bilateral, en el sentido de que la culpabilidad es condición necesaria y suficiente para la imposición de la pena. Una teoría

${ }^{32}$ Moore, Michael: Placing Blame, 1997, p. 97.

${ }^{33}$ Hart, H.L.A.: "Prolegomenon to the Principles of Punishment", 1968, p. 12. Para una objeción similar al utilitarismo de la regla, Smart, J.J.C.: "An Outline of a System of Utilitarian Ethics”, 1973, pp. 10-2, 42-57; Atria, Fernando: On Law and Legal Reasoning, 2001, pp. 127-129. 
mixta sólo atribuye a la culpabilidad el estatus de condición necesaria de la imposición de la pena, asignándole sólo una función unilateral ${ }^{34}$.

\section{c) ¿Prevención y culpabilidad como principios compatibles?}

En el marco de la teoría penal anglosajona, una teoría combinatoria de este tipo ha sido defendida, célebremente, por Herbert Hart. La premisa de la cual parte el argumento de Hart consiste en la tesis de que resulta imposible producir una justificación de la pena que sea moralmente aceptable a menos que uno distinga dos cuestiones involucradas: por una parte, la cuestión del objetivo general que cabe atribuir a la práctica punitiva; por otra, la cuestión de la distribución legítima de la imposición de la pena en un caso particular ${ }^{35}$. Esto parece evocar la concepción de Rawls, que, como se recordará, también descansa en la diferenciación entre la justificación de la práctica (punitiva) y la justificación de un acto (de punición) particular al interior de esa práctica.

A diferencia de Rawls, sin embargo, para Hart resulta ineludible reconocer que un mismo principio, independiente de cómo se lo modele, no puede ofrecer la solución a ambas cuestiones. Así, según Hart, debe aceptarse que en la producción de una justificación aceptable de la institución de la pena han de entrar en juego dos principios contrapuestos: el principio de utilidad, que determina el objetivo general de la práctica, y el principio de retribución, que constituye un criterio de justicia de la distribución de la imposición individual de la pena ${ }^{36}$. De este modo, el principio de retribución no constituiría un criterio positivo de justificación de la pena, pues ésta sólo puede entenderse legítima en tanto se orienta a la obtención de consecuencias sociales beneficiosas, sino sólo un criterio negativo de legitimidad de su imposición en el caso particular: el principio de retribución designa un criterio de distribución del costo asociado a la producción de esas consecuencias sociales beneficiosas, en el sentido de que sólo aquel que es culpable de un delito puede ser coaccionado a tolerar la "internalización” de ese costo. De esto se sigue que, en el marco de la teoría de Hart, la exigencia de culpabilidad sólo designa una condición necesaria, pero no suficiente, para la justificación de la (imposición de la) pena. Por eso, la teoría de Hart no es, propiamente, retribucionista.

${ }^{34}$ Así en Roxin, Claus: “Concepción Bilateral y Unilateral del Principio de Culpabilidad”, 1981, p. 187. En términos análogos, Moore, Michael: Placing Blame, 1997, pp. 88-89.

${ }^{35}$ Hart, H.L.A.: "Prolegomenon to the Principles of Punishment”, 1968, pp. $4-5$.

${ }^{36}$ Ibídem, pp. 9-11. 
En el contexto de la teoría penal alemana, un punto de vista coincidente con el de Hart se encuentra en la denominada "teoría dialéctica de la unión” defendida por Claus Roxin"37. Al igual que Hart, Roxin parte de la observación de que en la elaboración de una teoría aceptable de la justificación de la pena han de combinarse exigencias impuestas por principios contrapuestos. Por esto, la teoría de Roxin es una teoría de la combinación o unión de principios diferentes, cuya relación, sin embargo, es construida en términos de un juego de sucesivas restricciones recíprocas, o sea, como una relación dialéctica ${ }^{38}$. Así, Roxin entiende que hay que distinguir tres momentos en que, de manera distinta, para el Estado aparece la pregunta por la justificación de la pena: el momento de la conminación legal de la pena, el momento de su imposición y medición, y el momento de su ejecución.

En el momento de la conminación legal de la pena, se trata de la pregunta por las razones que debe ofrecer el legislador para justificar la decisión de fijar una exigencia de conducta reforzada por una amenaza de pena. En este nivel, según Roxin, la justificación sólo puede concebirse en términos de prevención general orientada a la protección de bienes jurídi$\cos ^{39}$. En el nivel de la imposición y medición judicial de la pena, si bien cabe reconocer un reforzamiento del efecto preventivo general de la pena, tanto en términos de una confirmación de la seriedad de la amenaza estatal (= prevención general negativa) como en términos de un reforzamiento simbólico de la norma quebrantada (= prevención general positiva), estas consideraciones se ven enfrentadas al límite impuesto por el principio de culpabilidad, que exige que la pena impuesta sea merecida por el sujeto condenado $^{40}$. Sólo de esta manera, según Roxin, una teoría que subordina la imposición de la pena a fines de prevención puede salvar la objeción kantiana, esto es, la objeción que apunta a que si la pena se impone por razones de prevención el individuo que la sufre es degradado a la condición de cosa, siendo sustraído del "reino de los fines", que es el dominio de la personalidad ${ }^{41}$. La pena se impone porque es preventivamente útil, pero ello queda condicionado por la exigencia de que el sujeto sea culpable y que el quantum de la pena a imponer no sobrepase la medida de su culpabilidad.

En el nivel de la ejecución de la pena, finalmente, Roxin reconoce la justificación de medidas que puedan conllevar la supresión o la modifica-

\footnotetext{
${ }^{37}$ Roxin, Claus: “Sentido y Límites de la Pena Estatal”, 1976, pp. 11-36.

${ }^{38}$ Ibídem, p. 34.

${ }^{39}$ Ibídem, pp. 20-24.

${ }^{40}$ Ibídem, pp. 27-31.

${ }^{41}$ Ibídem, pp. 28-29.
} 
ción de las condiciones de cumplimiento de la pena impuesta (por ej., a través de una libertad condicional) en tanto ellas resulten indicadas por razones de prevención especial, esto es, en atención a la maximización de las posibilidades de readaptación social del condenado, sin perjuicio de que en todo caso haya que reconocer, a su vez, una limitación a la aplicación de estas medidas, constituida por una salvaguarda mínima de la finalidad preventivo-general de la pena ${ }^{42}$. Así, aun de no haber consideraciones de prevención especial que justifiquen el cumplimiento efectivo de la pena impuesta (típicamente, una pena privativa de libertad), éste ha de mantenerse si su modificación conlleva una erosión de la confianza general en el sistema jurídico, es decir, una merma de su función de prevención general.

Lo crucial es advertir la correspondencia entre los planteamientos de Hart y Roxin. Lo que resulta común a ambos es la tesis de que la exigencia de culpabilidad ha de condicionar la imposición de la pena sin que por ello la culpabilidad pueda ser entendida como el fundamento positivo de la imposición de la pena. La implicación fundamental de una tesis como ésta se encuentra asociada a la posibilidad de que en un caso particular, por más improbable que éste sea, pudiese darse una situación en que no hubiera necesidad de pena por razones de prevención, satisfaciéndose empero las condiciones de la culpabilidad y, por ende, del merecimiento de pena. Una tesis que entiende que la culpabilidad no puede fundamentar positivamente la imposición de la pena tendría que afirmar que en tal situación no ha de imponerse la pena. La pregunta que cabe plantear entonces, nuevamente, aparece vinculada a la exigencia metodológica del equilibrio reflexivo: ¿es esa solución compatible con nuestras intuiciones morales básicas acerca de la institución de la pena?

\section{d) Incompatibilidad entre prevención y culpabilidad}

Sobre la base de un nuevo experimento mental, Moore sostiene que la respuesta a esta última pregunta es negativa, lo cual constituiría una razón para rechazar una teoría combinatoria o "mixta” de la justificación de la pena ${ }^{43}$. La clase de experimento mental que Moore sugiere se asemeja al conocido caso hipotético usado por Kant para mostrar el carácter incondicional (= categórico) de la exigencia de justicia retributiva. Moore propone imaginar un caso en que ninguna razón de utilidad pudiera ser aducida en apoyo de la imposición de la pena, por ejemplo, porque el asesino ha encontrado a Jesucristo y ya no resulta peligroso, por lo cual no habría argumen-

\footnotetext{
42 Ibídem, pp. 31-33.

${ }^{43}$ Moore, Michael: Placing Blame, 1997, pp. 97-102.
} 
tos de prevención especial a favor de la pena, así como porque el delito ha pasado inadvertido de manera que ninguna consideración de prevención general habla a favor de la misma ${ }^{44}$. Pero Moore también propone la siguiente variación de un caso real en que se trataba de un sujeto al cual se imputaba delitos de violencia sexual y robo: imagine Ud. que tras los hechos, pero antes de pronunciarse la sentencia, el acusado sufre un accidente que socava las bases fisiológicas de sus deseos sexuales e impulsos agresivos, de manera tal que él ya no representa un peligro por la posibilidad de delitos de violación futuros; además, imagine que el acusado recibe una herencia millonaria que vuelve completamente improbable que él vuelva a cometer un delito contra la propiedad en el futuro; por último, imagine que resulta posible fingir que el sujeto es sancionado sin que de hecho lo sea, para que así se satisfaga cualquier necesidad de prevención general que pudiera venir en consideración ${ }^{45}$.

La conclusión tendría que ser, conforme con una teoría mixta o combinatoria de justificación de la pena, que el sujeto no debería ser sancionado. Moore entiende, no obstante, que ello desafía el juicio moral que frente a tales casos parecemos formarnos, en el sentido de que el sujeto sí debería ser sancionado. Esto conduciría a un nuevo argumento de reducción al absurdo, cuya premisa mayor corresponda a la proposición, que recoge la tesis de una teoría combinatoria como la de Hart y Roxin, de que la pena sólo puede ser legítimamente impuesta si de ese modo se obtiene un beneficio social neto dentro de la medida de merecimiento del penado; cuya segunda premisa consista en la proposición de que en un caso tal la imposición de la pena no produciría un beneficio social neto; en cuya tercera premisa se recoja el juicio moral de que el sujeto sí debe ser sancionado, y cuya conclusión consista en que, por lo tanto, la pena debe y no debe ser impuesta ${ }^{46}$. A menos que se esté dispuesto a renunciar al juicio de que en tales casos (por más improbables que éstos sean) la imposición de la pena es correcta, la única posibilidad de evitar la conclusión contradictoria sería renunciar a la teoría combinatoria o pluralista ${ }^{47}$.

Es importante que Moore dé cuenta de que en defensa de una teoría combinatoria de la justificación de la pena todavía pudiese esgrimirse un argumento. Éste apuntaría a la introducción de un criterio de justicia formal, con arreglo al cual, aun cuando en casos como los propuestos la imposición de la pena no resulta preventivamente indicada, ello no obsta a que un

\footnotetext{
${ }^{44}$ Ibídem, p. 99.

${ }^{45}$ Ibídem, pp. 100-101.

${ }^{46}$ Ibídem, p. 101.

${ }^{47}$ Ibídem.
} 
beneficio social neto sí se siga de la punición en otros casos similares en que sí se dan las necesidades de prevención aquí faltantes, lo cual, combinado con la observancia de un requerimiento de igual justicia, exigiría que el culpable en aquellos casos también sea sancionado ${ }^{48}$. Como sostiene Moore, sin embargo, en un argumento como éste necesariamente se ha introducido, de manera subrepticia, una premisa retribucionista. La igualdad exige que los casos iguales sean tratados de igual modo, pero todo el problema consiste en determinar cuáles son las propiedades moralmente relevantes que dos o más casos han de compartir para que sean iguales. Ciertamente, la necesidad preventiva de pena no es una propiedad compartida por las dos clases de casos aquí considerados. La única propiedad común a ambas clases de casos es el merecimiento de pena de los sujetos de cuya punición se trata ${ }^{49}$. Juzgar las dos clases de casos como iguales presupone la identificación del merecimiento de pena por culpabilidad como la única propiedad moralmente relevante.

Que bajo una teoría pluralista o combinatoria se hace imposible evitar el carácter contradictorio de la conclusión acerca de si debe imponerse pena en tales casos, se explica porque la suposición fundamental que subyace a esa teoría, a saber, la suposición de que los criterios legitimantes pueden ser combinados, es falsa: una teoría de la unión necesariamente culmina en una neutralización recíproca entre los propósitos preventivos y el sentido retributivo de la imposición de la pena ${ }^{50}$.

\section{I.4. La imposición de la pena como acto expresivo}

Hasta el momento, la conclusión parece ser que una teoría que fundamente la legitimidad de la imposición de la pena, ya sea total o parcialmente, en consideraciones de prevención de delitos futuros no puede satisfacer algunas intuiciones morales importantes acerca de las condiciones bajo las cuales resulta correcta la imposición de una pena a alguien. Esto, a su vez, parece dejar en buen pie las posibilidades de éxito de una teoría retribucionista. La definición de "pena" que debía ser sometida a examen incluye una cláusula que designa un elemento de expresión de desaprobación. Para la defensa de una versión refinada de una teoría retribucionista de la justificación de la pena, la clarificación de este elemento resulta ser una cuestión crucial.

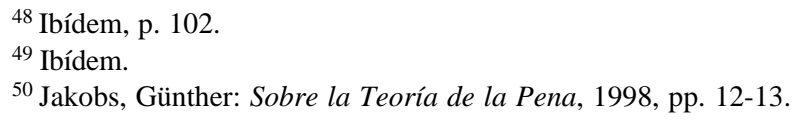




\section{a) La función expresiva de la pena}

La afirmación de que la noción de pena necesariamente incorpora una dimensión expresiva ha sido mantenida, en el contexto de la filosofía penal angloamericana, por Joel Feinberg ${ }^{51}$. La constatación inicial del argumento de Feinberg consiste en que las definiciones tradicionales de punishment han tendido a poner el énfasis en la irrogación del mal que conlleva la imposición de la pena, que Feinberg denomina hard treatment. Esto, sin embargo, volvería imposible dar cuenta de la distinción entre lo que puede entenderse propiamente como punishment, por una parte, y lo que puede entenderse como penalty, por otra ${ }^{52}$. La caracterización precisa y adecuada de lo que cabe entender por penalties, de modo de poder diferenciar a éstas de las formas de reacción propiamente punitivas, en todo caso, no resulta fácil. Así, Feinberg afirma que si bien en algunos casos las penalties admiten ser descritas como tasas que condicionan una licencia para realizar alguna actividad y que son aplicadas retroactivamente, en muchos otros casos ello no es posible; en estos casos, las penalties serían sanciones propiamente tales, aunque esto no sería suficiente para entenderlas como sanciones punitivas ${ }^{53}$. Lo crucial a este respecto es el reconocimiento de que lo único que hace posible diferenciar a éstas de aquéllas es una referencia a una característica funcional, por más similitudes que quepa reconocer desde el punto de vista de sus rasgos estructurales.

Lo distintivo de las sanciones punitivas, por ende, es una determinada propiedad funcional. Feinberg mantiene que la marca distintivamente punitiva de algunas sanciones está constituida por una función expresiva: la pena sería un dispositivo convencional para la expresión de actitudes de resentimiento e indignación, así como de juicios de desaprobación y reprobación, ya sea a nombre de la propia autoridad sancionadora o a nombre de aquellos en cuyo nombre la pena es impuesta" ${ }^{54}$. En principio, resulta posible diferenciar analíticamente este elemento expresivo del elemento de irrogación de un mal para determinar el peso de cada uno en la definición de lo que cabe entender por punishment. El punto está, sin embargo, en que a pesar de esta posibilidad de diferenciación analítica, esto es, a pesar de que es conceptualmente posible la existencia de formas de expresión de esas actitudes y juicios que no conlleven la irrogación de hard treatment, así

${ }^{51}$ Feinberg, Joel: “The Expressive Function of Punishment”, 1970, pp. 95118.

\footnotetext{
52 Ibídem, pp. 95-96.

${ }^{53}$ Ibídem, p. 97.

${ }^{54}$ Ibídem, p. 98.
} 
como es conceptualmente posible la existencia de formas de irrogación de hard treatment que no conlleven esa carga expresiva, es el caso que lo usual sea que la irrogación misma del mal desempeñe la función de expresar reproche y desaprobación, lo cual equivale a decir que ciertas formas de irrogación de mal se han convertido en símbolos inequívocos de reprobación ${ }^{55}$.

Esta observación de Feinberg resulta decisiva, pues ella contiene una validación implícita de la concepción del derecho penal como clase funcional. Que la irrogación del mal constituya el modo de expresión de ciertas actitudes y juicios implica una subordinación de la estructura a la función. Esto se mostraría, por ejemplo, en la consolidación de la idea, en el contexto del derecho penal angloamericano, de que respecto de formas de punibilidad por responsabilidad estricta ha de estar excluida la posibilidad de penas de presidio, dado que contemporáneamente éstas constituyen el modo de expresión de reprobación pública por antonomasia, lo cual estaría fuera de lugar tratándose de delitos de responsabilidad estricta, esto es, delitos cuya configuración no exige la satisfacción de los criterios generales de imputación subjetiva ${ }^{56}$.

La prioridad de la función expresiva frente a la característica estructural del hard treatment todavía no puede ser vista, sin embargo, como una redefinición pragmática de una fundamentación retributiva de la pena. Pues la dimensión expresiva de la pena parece susceptible de ser cooptada por alguna versión de una teoría prevencionista que fuese compatible con un tal “giro pragmático”. En la concepción del propio Feinberg parece haber un flanco abierto para una interpretación prevencionista de la dimensión expresiva de la pena. Esto, porque Feinberg entiende que identificar esa función expresiva de la sanción propiamente punitiva puede plantear la pregunta acerca de su relación con los distintos “propósitos generales” que tradicionalmente son asignados a la pena, así como puede contribuir a identificar otros propósitos, que generalmente son dejados de lado, los cuales inequívocamente presuponen esa función expresiva ${ }^{57}$. Dentro de los primeros, Feinberg menciona la intimidación general, la reforma y la rehabilitación del condenado. Dentro de los segundos, el desconocimiento autoritativo de actos por parte del Estado, la manifestación simbólica de que ciertas conductas no son toleradas, la vindicación del derecho y la absolución de otros sujetos de algún modo involucrados en los hechos juzgados.

\footnotetext{
${ }^{55}$ Ibídem, pp. 99-100.

${ }^{56}$ Ibídem, p. 111.

${ }^{57}$ Ibídem, pp. 101-105.
} 
El problema fundamental que con esto se suscita es que tales consideraciones admiten ser entendidas en términos de que la imposición de la pena, con su correspondiente carga expresiva, sería un medio para la materialización de tales efectos. Es esto lo que lleva a Moore a sostener que las teorías de la función expresiva o denunciation no representan más que una variante más de teoría utilitarista de la justificación de la pena. La pena se justificaría como un medio para la obtención de tales propósitos, aunque estos no estén reducidos a la prevención de delitos ${ }^{58}$.

\section{b) ¿Prevención general positiva?}

Algo similar cabe decir de lo que en el actual discurso de la teoría penal de influencia preponderantemente alemana se conoce como prevención general positiva, cuyo exponente más representativo es Günther Jakobs. En la formulación original de la teoría de Jakobs, por prevención general positiva se entiende el efecto comunicativo que tiene la imposición de la pena, a saber, el restablecimiento de la vigencia de la norma quebrantada por el delito ${ }^{59}$. Aplicando la noción, desarrollada en el marco de la sociología sistémica de Luhmann, de que las normas jurídicas pueden ser descritas como expectativas de comportamiento estabilizadas contrafácticamente, esto es, expectativas mantenidas a pesar del hecho de su frustración, esta versión de la teoría de la prevención general positiva concibe la imposición de la pena como un acto expresivo cuyo sentido es la confirmación de la vigencia de la norma quebrantada, o en términos un poco más esotéricos, la confirmación de la identidad normativa de la sociedad.

Esta consideración tiene importancia en tanto ella se corresponde de modo bastante preciso con la caracterización crítica que Moore hace de una de las dos variantes de teoría expresiva de la pena. Si bien una primera clase de teoría expresiva entendería que el objetivo que se persigue con la expresión de la condena social mediante la pena es la educación de los ciudadanos en cuanto al carácter incorrecto de las conductas que el derecho penal sanciona, de manera que ésta sería una variante propiamente prevencionista de teoría expresiva, cabe reconocer una segunda variante, que mantendría que la función de la denunciation sería contribuir al mantenimiento de la cohesión social ${ }^{60}$. En la medida en que la conservación de la cohesión social representa un estado de cosas valioso cuya obtención justificaría la imposición de la pena, esta variante de teoría expresiva, a pesar de no ser

\footnotetext{
${ }^{58}$ Moore, Michael: Placing Blame, 1997, pp. 84-85, 91-92.

${ }^{59}$ Jakobs, Günther: Strafrecht Allgemeiner Teil, 1991, pp. 5-14.

${ }^{60}$ Moore, Michael: Placing Blame, 1997, pp. 84-85.
} 
prevencionista, sí sería utilitarista, en el sentido de que lo que justifica la punición no es su valor intrínseco, sino sólo su valor instrumental ${ }^{61}$.

Que la teoría jakobsiana de la prevención general positiva pueda caracterizarse como utilitarista, empero, constituye una cuestión sumamente de difícil de establecer, sobre todo atendiendo al giro posterior que el propio Jakobs le diera en dirección hegeliana ${ }^{62}$. Manteniendo la tesis de que la función de la pena es la "confirmación de la realidad de las normas”, Jakobs sugiere que siguiendo esta concepción a partir de cierto punto deja de ser acertado hablar de un fin de la pena ${ }^{63}$. Jakobs afirma que la concepción de la pena como confirmación de la configuración normativa de la sociedad ciertamente se acerca bastante a la concepción identificada con la teoría de la prevención general positiva, según la cual la prestación específica que se realiza con la imposición de la pena es la confirmación de que la norma quebrantada sigue rigiendo como un esquema de orientación correcto, esto es, que la confianza en la norma es lo correcto ${ }^{64}$. Sin embargo, esta caracterización de la prevención general positiva resultaría, bajo la concepción posterior de Jakobs, demasiado “psicologizante”, en tanto la referencia a la confianza en la vigencia de la norma parecería encerrar una referencia a estados mentales de la generalidad de los individuos que pueden orientar su comportamiento con arreglo a esa norma. Si ha de conservarse la expresión de “prevención general positiva”, agrega Jakobs, el término "general” tendría que entenderse referido a que es lo general, o sea, la configuración de la comunicación que constituye a la sociedad, lo que resulta garantizado a través de la pena, mientras que el término “prevención” no ha de leerse como connotando un determinado efecto que se pretenda obtener a través de la pena, sino en el sentido de que la pena “como marginalización del significado del hecho en sí misma tiene como efecto la vigencia de la norma”65.

${ }^{61}$ Moore, Michael: Placing Blame, 1997, p. 92.

62 Jakobs, Günther: Sobre la Teoría de la Pena, 1998. Sobre esto también Pawlik, Michael: Person, Subjekt, Bürger, 2004, pp. 62-65. Es importante dar cuenta de que recientemente Jakobs ha vuelto a introducir una variación relevante en su concepción de la función de la pena estatal. Véase, Jakobs, Günther: La Pena Estatal: Significado y Finalidad, 2006, donde el énfasis aparece puesto, en contraste con su formulación precedente, en la facticidad de la pena referida a la salvaguarda cognitiva de la vigencia de la norma. Al respecto Silva Sánchez, Jesús: "Del Derecho Abstracto al Derecho 'Real”, 2006, pp. 377 ss.

63 Jakobs, Günther: Sobre la Teoría de la Pena, 1998, p. 15. En el mismo sentido, Lesch, Heiko: La Función de la Pena, 1999, p. 50.

${ }^{64}$ Jakobs, Günther: Sobre la Teoría de la Pena, 1998, p. 32.

${ }^{65}$ Ibídem, p. 33. 
Esta teoría inequívocamente concede prioridad a la dimensión expresiva de la pena por sobre el hecho bruto de la irrogación de un mal. De hecho, Jakobs se plantea la pregunta acerca de si es necesario que la comunicación operada con la imposición de la pena como “marginalización del significado del hecho” se materialice, de hecho, en la irrogación de un mal al autor del delito. La respuesta de Jakobs consiste en que, así como el hecho delictivo mismo no sólo es objetivado en el plano simbólico de su significado, sino también en el "mundo externo", la marginalización de ese significado a través de una mera declaración simbólica (o sea, lo que quedaría de la pena si se prescinde de la irrogación de un mal) padecería un déficit de objetivación en comparación con el hecho que ha de ser negado, de modo que "también la reacción frente al hecho [objetivado en el mundo externo] debe suponer una configuración definitiva"66. Y Jakobs agrega que esto nada tiene que ver con la orientación de la pena hacia algún efecto de intimidación o educación, sino sólo de contraponer la "realidad de la norma” al hecho de su quebrantamiento ${ }^{67}$.

\section{c) El sentido del quebrantamiento de la norma}

La objeción fundamental que cabe oponer a una teoría que entiende que la dimensión expresiva de la pena se encuentra referida a la confirmación de la identidad o configuración normativa de la sociedad se concentra precisamente en la suposición que a esta concepción subyace, a saber, la suposición de que el hecho punible, esto es, el quebrantamiento de la norma, haya de ser interpretado como un mensaje en el sentido de que la sociedad co-constituida por la norma quebrantada "no debe ser". Si el comportamiento punible constituye un quebrantamiento de la norma, lo es en el sentido de que ese comportamiento expresa una falta de reconocimiento del carácter vinculante de la norma: el autor del hecho punible expresa, a través de su comportamiento, una falta de reconocimiento de la norma como una razón eficaz para la acción. Pero esto no equivale a una toma de posición contraria a la existencia de la sociedad cuya configuración depende, entre otras cosas, de la vigencia de esa norma. Antes bien, es posible sugerir una redefinición del sentido expresivo del hecho punible conducente a la sugerencia más bien contraria, a saber, que lo que el autor del delito hace es aprovecharse injustamente de las ventajas que la coordinación social a través de normas asegura para todos. Ese aprovechamiento injusto de las

\footnotetext{
${ }^{66}$ Ibídem, p. 25.

${ }^{67}$ Ibídem.
} 
condiciones generales ventajosas puede justificar, bajo condiciones que aún deben ser establecidas, un reproche de culpabilidad. Si éste es el caso, la pena retributiva podría ser entendida como la materialización de ese reproche. Esto puede conducir a sentar las bases de una teoría expresivoretribucionista de la justificación de la pena.

\section{I.5. Expresión de reproche por el quebrantamiento de una norma legítima}

\section{a) Legitimidad de las normas de comportamiento}

Una de las implicaciones más significativas de una teoría retribucionista de la justificación de la pena está constituida por el énfasis que ella ha en la exigencia de la legitimidad de las normas de comportamiento cuya contravención culpable da lugar a la punición. Si la norma de comportamiento no es una norma legítima, su quebrantamiento no puede justificar reproche alguno ni, por ello, conllevar punición legítima alguna. Esta proposición es explícitamente afirmada por Moore, según quien una teoría retribucionista de la pena necesariamente exige que las normas de comportamiento que prohíben aquellas formas de conducta cuya realización culpable condiciona la imposición de la pena sean legítimas, o sea, que prohíban formas de conducta incorrecta $^{68}$. Moore constata, empero, que esto supone contradecir una intuición prevaleciente acerca de esta clase de teorías, a saber, la intuición de que la teoría retribucionista tendría como objeto de referencia la posición y el desempeño del adjudicador, pero no la posición ni el desempeño del legislador.

Esta idea, por más generalizada que se encuentre, es errónea. En la medida en que el juicio de merecimiento que gobierna la imposición de la pena retributiva está condicionado tanto por la antinormatividad del comportamiento como por la responsabilidad del sujeto por ese comportamiento, una teoría retribucionista de la pena conlleva exigencias para el legislador en cuanto a la definición de las normas de comportamiento cuyo quebrantamiento ha de conllevar un reproche penal ${ }^{69}$. Ciertamente, esto no implica que la función de las normas que definen formas de comportamiento incorrecto se reduzca a establecer estándares de evaluación de comportamientos para determinar su merecimiento de pena. Antes bien, las normas funcionan como directivas, esto es, como razones para la acción, para la

\footnotetext{
${ }^{68}$ Moore, Michael: Placing Blame, 1997, p. 70.

${ }^{69}$ Ibídem, p. 71.
} 
evitación intencional de tales formas de comportamiento. Pues de lo contrario habría que decir que la razón por la cual se establecen normas que protegen la propiedad sería posibilitar la punición del ladrón. Esto muestra, según Rawls, que el concepto de merecimiento moral es secundario frente a los conceptos de derechos y justicia ${ }^{70}$. El punto está en que al tratarse de un concepto secundario, su aplicación se encuentra subordinada a la satisfacción de algunos criterios derivados de los conceptos primarios correspondientes. Volviendo a la terminología del derecho penal: el juicio de merecimiento de pena no puede disociarse de aquellos estándares que definen qué comportamiento es justo y qué comportamiento injusto; y estos estándares son las normas que prohíben las formas de comportamiento cuya realización imputable constituye delito.

Acerca de esta implicancia de una teoría retribucionista se volverá más abajo. Lo que en este punto interesa es la posibilidad de identificar algunos criterios preliminares para analizar las condiciones de la legitimidad de las normas de comportamiento y la justificación de un reproche penal por su quebrantamiento. En principio, la única razón por la cual una norma puede ser considerada justa es que su seguimiento asegure ventajas para cada uno de sus destinatarios. Desde el punto de vista de la justicia como imparcialidad, una norma es justa en tanto su observancia es ventajosa para todos $^{71}$. Este criterio de legitimación de normas de comportamiento puede ser designado, siguiendo nuevamente a Kindhäuser, como principio de estricta universalización, que asegura la compatibilidad de la libertad de uno con la libertad de cada uno de los demás ${ }^{72}$.

\section{b) Culpabilidad como falta de reciprocidad}

A pesar que las normas que satisfacen esta exigencia de universalización pueden ser aceptadas por cualquiera de sus destinatarios como una razón vinculante para la acción, su justicia no obsta a su inestabilidad. Como ya se indicó, Kindhäuser remarca el hecho de que toda norma de comportamiento es necesariamente inestable desde el punto de vista de su seguimiento, en la medida en que si sus destinatarios se comportan de modo estratégicamente racional, para cada uno de ellos puede resultar individualmente ventajoso su incumplimiento ${ }^{73}$. Kindhäuser ilustra el punto re-

\footnotetext{
${ }^{70}$ Rawls, John: A Theory of Justice, 1971, p. 313.

${ }^{71}$ Ibídem, pp. 11-17.

${ }^{72}$ Kindhäuser, Urs: “Personalität, Schuld und Vergeltung”, 1989, p. 494.

${ }^{73}$ Ibídem, p. 496.
} 
curriendo al bien conocido dilema del prisionero, que muestra cómo en situaciones de falta de coordinación de la conducta individual de dos sujetos, la decisión estratégicamente racional para cada uno en un escenario de incertidumbre acerca de cómo actuará el otro necesariamente produce un resultado menos eficiente que el resultado que podría haber sido obtenido si la decisión hubiese tenido lugar en circunstancias diferentes ${ }^{74}$. La confianza de ego en cuanto a que alter no incumplirá la norma es condición necesaria para que para ego sea racional su cumplimiento.

El sujeto que no reconoce como vinculante una norma cuyo cumplimiento generalizado es beneficioso para todos, incluido él mismo, se aprovecha de la confianza depositada ex ante en él como persona moral por parte de los demás ${ }^{75}$. O sea, ese sujeto se posiciona como un free rider frente a aquellos con quienes se produce el reconocimiento recíproco de agencia moral. Puesto que el sujeto que actúa sin reconocer la norma como una razón para la acción pretende beneficiarse unilateralmente del cumplimiento generalizado de la norma, Kindhäuser afirma que lo que su comportamiento manifiesta es una falta de sentido de la justicia ${ }^{76}$, en la medida en que, como Rawls lo sugiere, una de las manifestaciones del sentido de la justicia de una persona se encuentra, precisamente, en la aceptación de instituciones justas con cuya vigencia ella y los demás se benefician ${ }^{77}$.

Sobre esta base, el reproche de culpabilidad puede ser visto como un reproche por una falla personal que muestra una falta de sentido de la justicia, de modo tal que ese reproche se expresa en la irrogación del mal en que se materializa la imposición de la pena. La pena, de este modo, resulta justificada como pena retributiva, pero su justificación no es absoluta, en el sentido de las teorías retribucionistas tradicionales, sino relativa ${ }^{78}$, en el sentido en que la pena expresa el reproche por un abuso unilateral de la confianza cuya reciprocidad es indispensable para la estabilidad de las normas de comportamiento cuyo seguimiento posibilita la coexistencia de iguales espacios de libertad. Que la imposición de la pena pueda reforzar las inhibiciones morales de ciudadanos que muestran fidelidad al derecho, sólo puede derivarse de su rol de expresión juicios reprobatorios acerca de determinadas conductas $^{79}$.

\footnotetext{
${ }^{74}$ Ibídem, pp. 496-497.

75 Ibídem, pp. 503-504.

${ }^{76}$ Ibídem, pp. 501-502.

${ }^{77}$ Rawls, John: A Theory of Justice, 1971, p. 474.

${ }^{78}$ Kindhäuser, Urs: "Personalität, Schuld und Vergeltung”, 1989, p. 504.

${ }^{79}$ Hirsch, Andrew von: Past or Future Crimes, 1985, p. 51.
} 


\section{I.6. Retribución, culpabilidad y determinismo}

\section{a) Determinismo y libertad de voluntad}

Uno de los argumentos que Roxin ofrece a favor de su tesis de que la culpabilidad sólo puede constituir un límite a la imposición de la pena, no su fundamento, consiste en que la posibilidad de culpabilidad humana presupondría "la libertad de voluntad (el libre albedrío)", cuya existencia, “como conceden incluso los partidarios de la idea de retribución, es indemostrable" ${ }^{80}$. O sea, puesto que la indeterminación del comportamiento humano no parece científicamente plausible, la noción de culpabilidad no podría invocarse como fundamento de la imposición de la pena. Si la culpabilidad es una ficción, dice Roxin, una concepción retributiva de la pena ofrecería una justificación ficticia de ésta. Por eso, sólo sería posible una justificación de la pena que descanse, positivamente, en la noción de prevención, y que sólo recurra a la ficción de la culpabilidad para restringir la imposición preventivamente orientada de la pena ${ }^{81}$. La premisa del argumento de Roxin entraña la tesis de que si la tesis del determinismo es correcta, la noción de libertad de voluntad que parece implicada en la idea de culpabilidad resultaría infundada. Pero esta asunción es incorrecta: la verdad del determinismo no obsta a la libertad de voluntad.

La pregunta es, entonces, cómo puede la libertad de voluntad ser afirmada incluso bajo la asunción de una concepción determinista del comportamiento humano. Esta proposición constituye el núcleo de lo que en la filosofía de la mente se conoce como compatibilismo ${ }^{82}$. Asumiendo que la libertad de acción y la libertad de decisión presuponen la existencia de alternativas $^{83}$, lo que una tesis compatibilista tiene que afirmar es que el hecho de que el comportamiento efectivamente realizado por el agente haya estado causalmente determinado no obsta a que sea verdad que el agente podría haber actuado y decidido actuar de modo diferente. La versión más célebre de esta tesis compatibilista, en el nivel de la libertad de acción, fue defendida por G.E. Moore, cuyo argumento se centra en la disponibilidad de dos interpretaciones divergentes de la cláusula "podría” que figura en esa

\footnotetext{
${ }^{80}$ Roxin, Claus: “Sentido y Límites de la Pena Estatal”, 1976, p. 13.

${ }^{81}$ Ibídem, p. 28.

${ }^{82}$ Schröder, Jürgen: Einführung in die Philosophie des Geistes, 2004, p. 312.

${ }^{83}$ Esta proposición no está exenta de controversia. La defensa más célebre de la
} tesis contraria se encuentra en Frankfurt, Harry: "Alternate possibilities and moral responsibility”, 1988. Para una discusión pormenorizada de este punto véase Widerker, David y Michael MacKenna: Moral Responsibility and Alternative Possibilities, 2003. 
proposición ${ }^{84}$. Si "podría” en "podría haber actuado de otro modo" se interpreta como incondicional, entonces esta proposición no es compatible con la aseveración de que el comportamiento realizado se encontraba causalmente determinado. Pues si el comportamiento estaba causalmente determinado, la proposición de que el sujeto podría haber actuado de otra manera es falsa. Pero "podría" admite ser interpretado en un sentido distinto, esto es, como una cláusula condicional. En este sentido, "podría haber actuado de otro modo" puede interpretarse como "podría haber actuado de otro modo, si hubiese decidido actuar de otro modo".

Bajo esta interpretación, que el comportamiento efectivamente realizado haya estado determinado resulta compatible con la afirmación de que el agente podría haber actuado de otro modo si hubiese decidido actuar de otro modo, pues de haber decidido actuar de otro modo las condiciones causalmente determinantes del comportamiento habrían sido diferentes. Esta defensa del compatibilismo en el nivel de la libertad de acción admite ser transferida al nivel de la libertad de voluntad, la cual, en los mismos términos, exigiría que el agente haya tenido una alternativa a la voluntad expresada en su decisión de ejecutar u omitir la acción en cuestión. Una interpretación compatibilista de la libertad de voluntad, entonces, tendría que atender a si el agente pudo haber decidido actuar de otro modo, de haber decidido decidir de otro modo.

La consideración fundamental a este respecto se encuentra en la idea de que la libertad de voluntad supone una capacidad de tomar decisiones, eficaces para la acción, de acuerdo a preferencias personales, que pueden ser reconducidas a preferencias más básicas, que son constitutivas de la propia identidad del agente. En la medida en que una acción esté determinada por condiciones que son internas a la identidad del agente, esa determinación del actuar puede ser reformulada como autodeterminación. Lo cual significa que la noción de libertad de voluntad no puede entenderse en términos de una falta de determinación causal del actuar. Si libertad de voluntad se entiende como autodeterminación, entonces la dicotomía relevante no es aquella que se da entre determinación e indeterminación, sino entre autonomía y heteronomía ${ }^{85}$. Y bajo esta redefinición de libertad como autodeterminación, se vuelve claro que la indeterminación de un comportamiento no puede fundamentar libertad alguna, pues que un evento sea inde-

\footnotetext{
${ }^{84}$ Schröder, Jürgen: Einführung in die Philosophie des Geistes, 2004, p. 313.

${ }^{85}$ Pauen, Michael: Illusion Freiheit?, 2004, pp. 59 ss., 105 ss.; Bieri, Peter: Das Handwerk der Freiheit, 2001, pp. 21 ss., 81 ss., 230 ss. En términos análogos, Baurmann, Michael: Zweckrationalität und Strafrecht, 1987, pp. 74 ss. Fundamental para el desarrollo de esta concepción, Dennett, Daniel: Freedom Evolves, 2003, pp. 25 ss., 97 ss., 259 ss.; también Mele, Alfred: Autonomous Agents, 1995, pp. 131 ss.
} 
terminado no significa otra cosa que su ocurrencia es azarosa o fortuita. Esto contraviene la función del concepto de autonomía como un criterio de agencia. Pues sólo es agente de un evento quien puede determinar, esto es, condicionar de modo contextualmente suficiente, la ocurrencia de ese evento.

Esta noción de libertad de voluntad, compatible con la verdad del determinismo, se encuentra reproducida en la concepción de Harry Frankfurt, que entiende la libertad de voluntad como la libertad de querer lo que se quiere querer ${ }^{86}$. El punto de partida se encuentra en la tesis de que lo distintivo de la condición de persona es la capacidad de formarse voliciones de segundo orden, esto es, voliciones acerca de las voliciones con las que el agente puede actuar. Las voliciones de segundo orden constituyen una clase especial de deseos de segundo orden, y son aquéllas y no éstos lo que distingue a una persona como tal. Esto hace posible diferenciar a una persona de lo que Frankfurt denomina un wanton, esto es, un individuo que aun pudiendo ser capaz de deliberar acerca de cómo hacer lo que quiere o desea hacer, tiene como característica esencial una indiferencia acerca de su propia voluntad ${ }^{87}$. Si bien esto implica que lo genuinamente distintivo de ser persona se encuentra en la dimensión de lo volitivo, la estructura de la voluntad de una persona presupone su carácter racional: sólo en virtud de ciertas capacidades racionales una persona es capaz volverse críticamente consciente de su propia voluntad y de formarse voliciones de segundo $\operatorname{orden}^{88}$.

\section{b) Autonomía y responsabilidad}

El ejercicio de la libertad de voluntad consiste, entonces, en asegurar la conformidad de la voluntad con las propias voliciones de segundo orden. La libertad de voluntad se ve afectada, por ende, cuando tiene lugar una discrepancia entre ciertas voliciones de segundo orden y la voluntad realizada en la acción, o bien cuando la congruencia entre ésta y aquéllas es puramente fortuita ${ }^{89}$. Y como observa el propio Frankfurt, esta concepción de la libertad de voluntad en modo alguno supone una defensa del indeterminismo. Según Frankfurt, es perfectamente concebible que esté causalmente determinado que una persona sea libre de querer lo que quiere querer ${ }^{90}$. p. 20 .

${ }^{86}$ Frankfurt, Harry: "Freedom of the Will and the Concept of a Person”, 1988,

\footnotetext{
${ }^{87}$ Ibídem, pp. 16-17.

${ }^{88}$ Ibídem, p. 17.

${ }^{89}$ Ibídem, pp. 20-21.

${ }^{90}$ Ibídem, p. 25.
} 
Lo crucial es que en algún punto de la indagación en la cadena de condiciones causales se ha de alcanzar un punto en el cual las condiciones en cuestión aparecerán como constitutivas para la persona, en el sentido que co-definen su propia identidad, lo cual rompe un posible regreso al infinito. Que sea difícil establecer qué preferencias cuentan como elementos definitorios de la identidad de una persona no implica que esas preferencias no $\operatorname{existan}^{91}$. Y en ese nivel, la pregunta por la posibilidad de una alternativa se transforma en una pregunta por la posibilidad de que esa persona sea alguien distinto. Y esta pregunta carece de sentido, cuando de lo que se trata es de explicar las acciones y las decisiones de esa persona: la pregunta de si yo soy libre de mí mismo carece de sentido, porque entonces el pronombre "yo" carecería de objeto de referencia. Pues como sarcásticamente sugiere Dennett: "If you make yourself really small, you can externalize virtually everything" ".

Que la acción humana está causalmente determinada no obsta, entonces, a su carácter de autónoma. Y si la noción de culpabilidad descansa en una capacidad personal de formarse y realizar intenciones de segundo orden, la verdad del determinismo no implica que el fundamento de la pena retributiva descanse en una ficción. Por lo demás, ésta es exactamente la conclusión que alcanza Hart al analizar una posible objeción determinista, en el sentido del incompatibilismo, al reconocimiento de condiciones de excusa como criterios de exclusión de la responsabilidad penal. Si la determinación del comportamiento fuese incompatible con la autonomía del comportamiento, no tendría sentido reconocer una diferencia moral significativa entre la punición de un sujeto en quien se da una condición de excusa y la punición de un sujeto en quien ella no se da, en tanto por condiciones de excusa se entienda circunstancias en las cuales la acción aparece causalmente determinada ${ }^{93}$. Pero si la tesis incompatibilista fuera correcta, esa concepción de las condiciones de excusa tendría que carecer de sentido, pues en sus propios términos todo sujeto debería ser siempre excusado, puesto que su comportamiento siempre estará causalmente determinado.

Esto sólo habla en contra de la concepción de las condiciones de excusas que conduce a esta conclusión ${ }^{94}$. Lo distintivo de una condición de excusa no es que ella haga referencia al carácter causalmente determinado del comportamiento en cuestión, sino bien a una falta de capacidad

\footnotetext{
${ }^{91}$ En este sentido Pauen, Michael: Illusion Freiheit?, 2004, pp. 75 ss.

92 Dennett, Daniel: Freedom Evolves, 2003, p. 122.

${ }^{93}$ Hart, H.L.A.: "Legal Responsibility and Excuses", 1968, pp. 28-53, 28-29.

${ }^{94}$ Sobre esto, en detalle, Moore, Michael: Placing Blame, 1997, pp. 481-547.
} 
personal para motivarse a formar una determinada decisión, o bien a la inexigibilidad de adoptar una determinada decisión bajo determinadas circunstancias. Y a este respecto es completamente irrelevante que toda decisión pueda ser explicada causalmente ${ }^{95}$. La determinación causal no constituye, por ende, una categoría relevante en el contexto de la atribución de autonomía y responsabilidad personal.

\section{I.7. La justificación moral de la retribución}

\section{a) La neutralidad metaética del principio de retribución}

Despejado el camino de una posible objeción incompatibilista a la fundamentación retributiva de la pena, puede emprenderse el análisis de la justificación del principio de retribución desde el punto de vista moral. A este respecto, puede ser oportuno volver sobre la estrategia de los experimentos mentales usada por Moore. Los experimentos consistían en una apelación al juicio moral que parece contradecir la conclusión que tendría que inferirse a partir de la proposición de que la pena sólo puede imponerse si ella produce alguna consecuencia ulterior que es socialmente beneficiosa (la premisa mayor) y de la proposición de que en el caso imaginado la punición no conllevara la producción de consecuencia favorable alguna (la premisa menor), conclusión consistente en que en tal caso la punición debería ser negada. Puesto que esto contravendría nuestro juicio moral de que en tal caso el sujeto sí habría de ser sancionado, la única posibilidad de conservar ese juicio moral sería prescindiendo de la proposición expresada en la premisa mayor del argumento. De este modo, la punición del sujeto resultaría consistente con una concepción retribucionista de la función de la pena, de acuerdo con la cual el merecimiento constituye una razón suficiente para la punición.

La pregunta que entonces puede presentarse apunta a la validez de esta estrategia de justificación de una teoría retribucionista. ¿Por qué ha de concluirse que la teoría retribucionista es correcta por el solo hecho de que en un experimento mental como el propuesto nuestro juicio moral parezca consistente con la validez del principio de la retribución? Un argumento conceptual, concentrado en el análisis semántico de "pena", como ya vimos, no puede estimarse pertinente, dado el vicio de definitional stop que encierra. Por eso, lo crucial es el esbozo de una justificación moral del principio de retribución. Una de las contribuciones más significativas de Moore a este respecto consiste en su observación de que una justificación retribu-

${ }^{95}$ Hart, H.L.A.: “Legal Responsibility and Excuses”, 1968, pp. 44-48. 
cionista de la pena no presupone, necesariamente, una matriz deontológica de teoría moral, como contrapuesta a una matriz teleológica o consecuencialista ${ }^{96}$. Esta última es una distinción cuyo estatus es el de la reflexión metaética, esto es, el de la reflexión acerca de las propiedades distintivas de los enunciados morales, independientemente de la clase de teoría moral sustantiva a la cual ellos puedan ser adscritos.

Lo distintivo de una concepción deontológica de la moral es la idea de que los enunciados morales, esto es, los enunciados que determinan las condiciones del carácter moralmente correcto de una acción, una decisión o una práctica, presuponen la identificación de normas categóricas que son relativas-al-agente, en el sentido de que esas normas obligan a sus destinatarios sin que sea pertinente la consideración de la maximización de su seguimiento en ocasiones distintas de aquélla en que actualmente la norma obliga ${ }^{97}$. Lo distintivo de una concepción consecuencialista o teleológica de la moral, en cambio, es la idea de que el carácter moralmente correcto de una acción, una práctica, etc., es función exclusiva de la bondad de las consecuencias que ella produce ${ }^{98}$. La cuestión que aquí interesa es que sería posible concebir una justificación retribucionista de la pena que descanse en una metaética consecuencialista. Bajo una concepción tal, lo que el principio de retribución exigiría es la maximización de la punición de aquellos que lo merecen, en tanto estado de cosas valioso ${ }^{99}$. La justificación moral del principio de retribución, por ende, es neutral frente a la dicotomía deontología-teleología en la indagación metaética.

\section{b) Holismo como estructura de justificación}

La estrategia de justificación del principio de retribución que Moore despliega, por otra parte, supone la adopción de un punto de vista coherentista u holista, lo cual a su vez supone negar que haya algo así como principios auto-evidentes que sirvan como fundamento último en la cadena de justificación moral. Si el principio de retribución no puede ser reducido a

${ }^{96}$ Moore, Michael: Placing Blame, 1997, p. 155-159. Para una formulación diferente de la posibilidad de un retribucionismo consecuencialista, Tunick, Mark: $\mathrm{Pu}$ nishment. Theory and Practice, 1992, pp. 162-164.

${ }^{97}$ Moore, Michael: Placing Blame, 1997, p. 155.

${ }^{98}$ Véase también Mackie, John: Ethics. Inventing Right and Wrong, 1977, pp. 149-168.

${ }^{99}$ Moore, Michael: Placing Blame, 1997, pp. 157-158. Para una distinción correspondiente entre utilitarismo y consecuencialismo, en el sentido de que todo utilitarismo es consecuencialista, pero no todo consecuencialismo es utilitarista, Williams, Bernard: “A Critique of Utilitarianism”, 1973, pp. 77-79, 82-93. 
un principio más básico, ello de ninguna manera implica que el principio de retribución no requiera de justificación. La estrategia de Moore consiste en justificar el principio de retribución a modo de una inferencia inductiva a partir de principios más concretos y juicios morales particulares, como aquellos que se reconocen en los experimentos mentales ya analizados ${ }^{100}$, así como identificando algún principio más general del cual el principio de retribución pudiera ser inferido deductivamente. De lo que se trata es de ajustar el juicio moral particular en el marco total de un sistema de juicios y principios morales, algunos más generales y otros más particulares que aquél ${ }^{101}$.

En esto consiste, por lo demás, el modo de justificación moral que es distintivo de lo que Rawls denomina "equilibrio reflexivo", de acuerdo con el cual la justificación de un principio siempre requiere que éste sea examinado en el contexto global de una serie de otros principios generales y de juicios e intuiciones particulares, los cuales deben ir siendo modificados y ajustados entre sí hasta alcanzarse una situación, siempre provisional, de equilibrio, sin que ni a los primeros ni a los segundos corresponda un estatus preferencial en ese proceso de ajuste ${ }^{102}$. Por supuesto, mientras más concluyente parezca ser un juicio moral en cuestión, mayor será el peso de ese juicio en el proceso de ajuste, de modo que el principio que condiciona la legitimidad de la punición a la obtención de un efecto preventivo pueda ser abandonado. El peso de ese juicio, empero, no puede tenerse por establecido de antemano. Aquí es pertinente considerar dos objeciones que, según el propio Moore, pueden ser dirigidas en contra de esta justificación holista del principio de retribución. Una apunta al supuesto carácter (viciosamente) circular del argumento, mientras que la otra, a su supuesta invalidez por depender de una inferencia hecha a partir de emociones.

La objeción relativa al carácter circular de la justificación puede construirse en términos de que el juicio particular que aparece como relevante en los experimentos mentales en cuestión, a partir del cual podría generalizarse el principio de retribución, tendría el mismo contenido que éste, o bien en términos de que en todo caso ese juicio particular ya es un juicio retributivo ${ }^{103}$. En una y otra forma, no obstante, la objeción es inconducente. Ella presupone que la formulación del juicio particular, según el cual en un caso como el del experimento mental sí debería imponerse pena, a pesar de no haber necesidad preventiva, es equivalente a la formulación del

\footnotetext{
${ }^{100}$ Moore, Michael: Placing Blame, 1997, pp. 161-162.

${ }^{101}$ Ibídem, pp. 49-55.

${ }^{102}$ Rawls, John: A Theory of Justice, 1971, p. 48.

${ }^{103}$ Moore, Michael: Placing Blame, 1997, pp. 165-167.
} 
principio de retribución. Esta presuposición es errada, sin embargo, pues el principio de retribución sólo es formulado como una abstracción de juicios morales particulares sobre la base de la identificación de una propiedad moralmente relevante que puede ser encontrada en cada uno de esos juicios particulares. Para que la objeción de una petición de principio fuese exitosa, los juicios morales particulares tendrían que enunciar algo así como "en tal caso el sujeto debe ser sancionado sólo porque lo merece”. Pero esa formulación sólo es alcanzada una vez que se ha inferido un principio general a partir de una serie de juicios particulares a través de los cuales se expresa que la punición se considera correcta en relación con el caso examinado. Lo que sugieren los casos como el del experimento mental es que la propiedad moralmente relevante identificada en cada caso es el merecimiento de pena, y no su indicación preventiva. Pero esto no es algo que esté presupuesto en la formulación de cada uno de los juicios particulares ${ }^{104}$.

Moore da cuenta de que entonces podría objetarse que la noción misma de merecimiento no designa más que la adecuación de la imposición una sanción retributiva, por lo cual de todas formas la justificación del principio de retribución resultaría circular. A esto Moore replica que semejante reducción del significado de "merecimiento" equivaldría a definir "enfermedad" como una instancia adecuada para la intervención de un médi$\mathrm{Co}^{105}$. La noción de merecimiento no es vacía, sino que, al menos en contextos de merecimiento de reproche, designa una conjunción de criterios de incorrección de formas de comportamiento (wrongdoing) y de responsabilidad personal (culpability). Que la satisfacción de estas condiciones de responsabilidad personal por formas de comportamiento incorrecto fundamente un juicio de merecimiento de pena, y que éstos a su vez sean suficientes para la justificación de la imposición de una pena, no es algo que esté siendo prejuzgado cada vez que alguien afirma, frente a un caso como el del experimento mental, que la punición resulta correcta ${ }^{106}$.

Lo anterior es importante en tanto parece sugerir que el principio de retribución, además de ser inferido de juicios morales particulares, también resulta apoyado en un principio más general, del cual podría ser deductivamente inferido. Tal podría ser el estatus de un principio general de merecimiento ${ }^{107}$. Se trata de un principio más general que el principio de retribución, puesto que el mismo no presupone que lo merecido sea necesariamente un reproche por un acto incorrecto; el principio de merecimiento

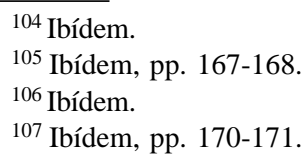


también está implicado en la atribución de mérito por actos correctos ${ }^{108}$. La relación entre este principio general de merecimiento y el principio de retribución es que, de acuerdo con este último, el merecimiento es condición necesaria y suficiente para la legitimidad de la imposición de la pena. En este punto, sin embargo, es crucial advertir la sensibilidad contextual del uso de esta noción de suficiencia. La tesis de que el merecimiento es condición suficiente para la imposición de la pena ha de entenderse en el sentido de que, entre todas aquellas condiciones que pueden ser vistas como posibles razones para la punición, el merecimiento es suficiente para su justificación. Esto ciertamente no implica que no haya otra clase de condiciones, distintas de aquellas que pueden constituir razones posibles para la punición, que efectivamente son necesarias, pero que en la discusión acerca de las razones admisibles para la punición pueden ser dadas por supuestas ${ }^{109}$.

\section{c) La función de las emociones en el razonamiento moral}

Hasta este punto, el argumento de Moore consiste en mostrar cómo a partir de juicios particulares podría ser inferido un principio general de retribución, el cual al mismo tiempo aparece como una concreción de un principio más general de merecimiento, sin que esa inferencia resulte viciada por una petición de principio. La objeción que todavía quedaría por enfrentar apunta a las bases emocionales de la formulación de esos juicios morales particulares. La objeción consiste en impugnar esta justificación del principio de retribución, dado el carácter emocional de su origen. Como el propio Moore lo sugiere, la evaluación de esta objeción requiere de una clarificación de la relación que se da entre nuestras emociones y nuestros juicios morales $^{110}$.

Bajo una metaética emotivista, por ejemplo, el significado de un enunciado moral aparecería reducido a la expresión de ciertas emociones frente a una situación determinada. Es claro, sin embargo, que ésta no es la única forma posible de articular la relación entre enunciados morales y emociones. Bajo cualquier versión de una metaética cognitivista o racionalista, esto es, una concepción de acuerdo con la cual los enunciados morales pueden ser correctos o incorrectos (lo cual no equivale a que puedan ser verdaderos o falsos), su significado no puede estar determinado por la expresión de emociones. Pero esto no implica que las emociones sean irrelevantes para la identificación de juicios y principios morales. Antes bien, las

\footnotetext{
${ }^{108}$ Feinberg, Joel: “Justice and Personal Desert”, 1970, pp. 55-94.

${ }^{109}$ Moore, Michael: Placing Blame, 1997, pp. 173-174.

110 Ibídem, pp. 181-184.
} 
emociones pueden tener una importante función heurística en la identificación de esos principios, o sea, pueden contribuir al descubrimiento de nuestros principios morales. Y contra lo que pudiera ser un lugar común, las emociones parecen presentar algunas características que apoyan su consideración como guía en la identificación de principios. Tanto en el hecho de que las emociones, tal como las creencias y otras actitudes proposicionales, tengan contenido intencional (esto es, puedan estar referidas a un objeto cuya existencia o inexistencia es independiente del portador de la actitud en cuestión), como en el hecho de que parezcan sujetas a ciertas leyes de proporcionalidad (pues de lo contrario sería imposible juzgar una determinada emoción como inapropiada o excesiva), se muestra que no es insensato hasta cierto punto confiar en las emociones para una identificación provisoria de principios morales con arreglo a los cuales evaluar nuestras acciones y prácticas ${ }^{111}$.

Esta última descripción se ajusta a lo que se conoce como una teoría cognitiva de las emociones, de acuerdo con la cual las emociones presentan contenido cognitivo, en el sentido de que ellas admiten ser consideradas como correctas o incorrectas de acuerdo a parámetros de racionalidad ${ }^{112}$. Una de las implicaciones del hallazgo del contenido cognitivo de las emociones es que éstas aparecen como susceptibles de control, de modo que cobra sentido la posibilidad de tener responsabilidad por las emociones que se tiene ${ }^{113}$.

Para dar cuenta de las emociones que pueden estar implicadas en la formulación de un juicio moral particular relevante para la inferencia del principio de retribución, puede ser conveniente, nuevamente siguiendo a Moore, considerar la posibilidad de construir los experimentos mentales de dos maneras distintas, a saber, en perspectiva de tercera persona y en perspectiva de primera persona ${ }^{114}$. Si el experimento se formula en perspectiva de tercera persona, esto es, si el sujeto de cuya punición se trata es un tercero, la afirmación de ésta podría aparecer fundada en alguna variante de resentimiento o de lo que Strawson denomina una actitud reactiva, esto es, aquella clase de respuesta emocional a lo que otro hace que es congruente con su reconocimiento como un sujeto que toma parte en la comunicación entre personas, o sea, como un agente moral. Reprochar algo a alguien es,

\footnotetext{
${ }^{111}$ Ibídem.

112 Pillsbury, Samuel: "Emotional Justice: Moralizing the Passions of Criminal Punishment”, 1989, pp. 675 ss.

113 Ibídem, pp. 677-679.

${ }^{114}$ Moore, Michael: Placing Blame, 1997, pp. 163-5.
} 
por lo mismo, incompatible con la adopción de una actitud objetivante, que supone ver al otro como un objeto de táctica social ${ }^{115}$.

Desde este punto de vista, el principio de retribución aparece como una instancia particular de un principio más general de respeto hacia otros, según el cual las personas han de ser respetadas por su capacidad de reconocer y llevar a cabo elecciones morales libres ${ }^{116}$. En el contexto de la punición, en que se trata de la respuesta adecuada a un comportamiento prohibido o incorrecto por el cual se es responsable, este principio de preocupación por el otro se corresponde con una emoción de indignación moral $^{117}$. Si veo en el otro alguien que me importa, lo que él o ella haga no puede dejarme indiferente. El carácter moral de esta indignación, esto es, su relevancia moral, empero, supone que esa emoción encuentra apoyo en razones morales. Es este apoyo en razones morales lo que vuelve inviable el alegato tradicional de que la pena retributiva no sería más que un mecanismo de ejecución de venganza. Precisamente, la diferencia entre indignación y venganza se encuentra en que la primera emoción es susceptible de ser apoyada en razones que son moralmente pertinentes. En terminología hegeliana: la retribución es expresión de una voluntad que quiere lo general, esto es, que trasciende su propia particularidad, y es precisamente esto lo que la distingue de una reacción puramente vengativa ${ }^{118}$.

A este respecto, es suficientemente ilustrativa la analogía que Pillsbury sugiere entre la relación entre venganza e indignación, por una parte, y la relación entre eros y ágape, por otra ${ }^{119}$. Ambos términos son denominaciones para la noción de amor. Pero mientras que el amor erótico designaría una vinculación con otro en persecución de un interés propio, el ágape representaría un afecto que carece de toda motivación auto-interesada. Ciertamente, esto no supone atribuir una connotación peyorativa al amor erótico. El punto está en que ésta es una forma de pasión que no se conecta con un trasfondo de moralidad. Lo mismo sucede con la venganza, que de este modo puede verse como una disposición amoral o no-moral. La indignación, en cambio, es moralmente significativa en tanto susceptible de descansar en un trasfondo de razones moralmente relevantes. La inferencia del principio de retribución a partir de un juicio moral que entraña esa actitud reactiva,

${ }^{115}$ Strawson, P.S.: Libertad y Resentimiento, 1995, pp. 46-47.

116 Pillsbury, Samuel: "Emotional Justice: Moralizing the Passions of Criminal Punishment”, 1989, p. 686.

${ }^{117}$ Ibídem, p. 689.

${ }^{118}$ Hegel, G.W.F.: Grundlinien der Philosophie des Rechts, 1970, §§ 102-103. Véase también Nozick, Robert: Philosophical Explanations, 1981, pp. 366-370.

119 Pillsbury, Samuel: "Emotional Justice: Moralizing the Passions of Criminal Punishment”, 1989, pp. 686-687, 690. 
entonces, muestra cómo el principio de retribución es congruente con el reconocimiento del otro, el destinatario del reproche, como un agente moral. Ésta es una virtud fundamental de la justificación retribucionista de la pena.

\section{c) Solipsismo y escepticismo}

Pero también es importante atender a las emociones que pueden venir en consideración frente a una construcción del experimento mental en primera persona, esto es, bajo la suposición de que el sujeto de cuya punición se trata es uno mismo, que es la variante que más interesa a Moore ${ }^{120}$. El juicio moral de que en tal caso la punición es correcta conllevaría alguna emoción parecida al sentimiento de culpa. Usando la terminología de Kindhäuser, ésta tendría que ser la respuesta emocional de un sujeto moralmente maduro frente a la constatación de que se ha aprovechado injustamente, como un free rider, de la ventaja que el cumplimiento de la norma por parte de los demás le reporta. La conveniencia de esta formulación en primera persona se encontraría en que ella no parece generar el mismo grado de resistencia que a veces genera la constatación de resentimiento hacia otros. Mas aquí la tentación podría consistir, como el propio Moore señala, en negarse a generalizar el juicio moral condenatorio para que así también resultara aplicable a otros. Pero esto, lejos de evidenciar generosidad o magnanimidad, sólo mostraría lo que Moore califica de arrogancia elitista ${ }^{121}$. Quien negare que los demás pueden verse sujetos a los mismos estándares de evaluación que uno se aplica a sí mismo sería algo así como un solipsista moral, o sea, alguien que no está dispuesto a reconocer a otros como sujetos capaces de vivir moralmente ${ }^{122}$.

Cualquiera que sea la vía, entonces, la conclusión es la misma: el rechazo de la justificación retribucionista de la pena implica una ausencia de la disposición a reconocer al autor del delito como un igual agente moral. Probablemente, esto resultará insuficiente para convencer al escéptico. Lo que el escéptico no puede negar, sin embargo, es que la alternativa de mantener la defensa de una justificación utilitarista de la práctica punitiva supone el mismo grado de compromiso moral. El principio de utilidad tiene la misma carga moral que un principio de merecimiento; la justificación utili-

${ }^{120}$ Moore, Michael: Placing Blame, 1997, pp. 164-165.

${ }^{121}$ Ibídem, p. 165.

${ }^{122}$ En la filosofía de la mente, por solipsismo se entiende la proposición según la cual uno es el único individuo que tiene estados mentales, proposición que ciertamente puede formularse con diverso grado de intensidad. Véase Searle, John: Mind: A Brief Introduction, 2004, pp. 13-14. 
tarista de la pena se encuentra tan moralmente comprometida como la justificación retribucionista de la pena ${ }^{123}$. La diferencia sólo se encuentra en la matriz de racionalidad subyacente. Lo que el utilitarista tiene que sostener es que la matriz del economista es la que debe prevalecer. El único camino para el escéptico tendría que ser el abolicionismo, que es el lugar adonde lleva el solipsismo en el contexto de la teoría penal ${ }^{124}$.

\section{LA RETRIBUCIÓN COMO TEORÍA DEL DERECHO PENAL}

\section{II.1. La pena retributiva como expresión de reproche}

a) El reproche penal como acto ilocucionario

Bajo una concepción retribucionista reconstruida en términos de lo que Feinberg denomina la función expresiva de la pena, ésta consiste en expresar un reproche merecido por un comportamiento incorrecto que es imputable como acción culpable. Esta expresión de reproche no es un medio para la obtención de una consecuencia ulterior, por ejemplo, la prevención de delitos futuros, sino que se justifica por el solo hecho de que ese reproche es merecido. Esto se sigue de la contraposición que, siguiendo a Strawson, cabe reconocer entre la expresión de una actitud reactiva y la adopción de una actitud objetivante ${ }^{125}$. Si la imposición de la pena constituye una modalidad de expresión de desaprobación o reproche, la pena no puede ser impuesta para que a través de la expresión de reproche el propio sujeto penado o la generalidad de las personas sean intimidados, o éstas vean reforzada su disposición a cumplir con las normas vigentes, etc. Una expresión de reproche hecha para la obtención de determinadas consecuencias por definición deja de constituir un reproche, aun cuando se lo presente como tal y haya base para el mismo ${ }^{126}$. En tal caso se trata de la ficción de un reproche, y el carácter ficticio del reproche se explica por el predominio de una actitud objetivante, o sea, por la consideración del auténtico destinatario de la imposición de la pena (el propio penado, en términos de pre-

${ }^{123}$ Véase Moore, Michael: “Moral Reality”, 1982, pp. 1067 ss.

${ }^{124}$ Para una caracterización de la crítica radical de corte abolicionista al sistema penal como una posición escéptica, Tunick, Mark: Punishment. Theory and Practice, 1992, pp. 17-66.

${ }^{125}$ Strawson, P.S.: Libertad y Resentimiento, 1995, pp. 46 ss.

126 Ibídem, p. 47. Para un intento de relativizar esta distinción de cara al problema de la justificación de la intervención punitiva, Baurmann, Michael: Zweckrationalität und Strafrecht, 1987, pp. 145 ss. 
vención especial; la generalidad de los individuos, en términos de prevención general) como un objeto de táctica social. En la formulación del reproche, también en la formulación del reproche mediante pena, hay una condición de sinceridad que es constitutiva de lo que cuenta cómo efectuar un reproche.

Para analizar el estatus que cabe atribuir a esta condición constitutiva puede ser útil emprender la reconstrucción de la imposición de la pena como un acto de habla ${ }^{127}$. En su versión más tradicional, la teoría de los actos de habla desarrolla una distinción entre tres niveles en que puede analizarse lo que un hablante hace cuando habla. En la formulación de J.L. Austin, se trata de la distinción entre acto locucionario, acto ilocucionario y acto perlocucionario ${ }^{128}$. Por acto locucionario Austin entiende el acto de emitir o proferir una oración con una cierta referencia y un cierto sentido, o sea, con cierto significado. Por acto ilocucionario, en cambio, Austin entiende el acto que se realiza en la ejecución del acto locucionario bajo ciertas condiciones que, convencionalmente, determinan una cierta fuerza (ilocucionaria). Así, cuando un sujeto emite una determinada oración en las circunstancias adecuadas puede estar realizando una aseveración, formulando una pregunta, dando una orden, etc. Por último, por acto perlocucionario Austin entiende el acto por el cual el hablante persigue ciertas consecuencias o efectos a través de su acto de habla. De ahí que, siguiendo a Searle, sea preferible utilizar el adjetivo "perlocucionario" para designar cierta clase de efectos que pueden seguirse de la realización de un acto ilocucionario ${ }^{129}$. Tal como lo resume Habermas, lo que así se distingue es "decir algo; hacer algo diciendo algo; causar algo mediante lo que se hace diciendo algo"130.

La formulación de un reproche puede ser entendida como un acto ilocucionario. En el marco de la teoría de Austin, el análisis de este tipo de acto de habla requiere identificar la fuerza ilocucionaria que lo distingue como tal, esto es, que lo constituye como ese acto de habla y no otro. Austin mismo ofreció una clasificación de las fuerzas ilocucionarias que resultaba en una diferenciación de cinco tipos generales de actos ilocucionarios: los "veredictivos" (verdictives), los "ejercitivos" (exercitives), los "compromisorios" (commissives), los "comportativos" (behabitives) y los “expositivos” (expositives) ${ }^{131}$. Esta clasificación de las fuerzas ilocuciona-

\footnotetext{
${ }^{127}$ Véase Nozick, Robert: Philosophical Explanations, 1981, pp. 370-374.

${ }^{128}$ Austin, J.L.: How to Do Things with Words, 1975, pp. 94-120.

${ }^{129}$ Searle, John: Speech Acts, 1969, p. 25.

${ }^{130}$ Habermas, Jürgen: Teoría de la Acción Comunicativa, 1999, t. I, p. 371.

${ }^{131}$ Austin, J.L.: How to Do Things with Words, 1975, pp. 148-164.
} 
rias ha sido, con razón, dejada de lado en el desarrollo posterior de la teoría de los actos de habla ${ }^{132}$.

Sin perjuicio de esto, es importante considerar la posición que un acto de reproche podría tener dentro del esquema clasificatorio de Austin, pues de esta manera pueden hacerse patentes algunas de sus peculiaridades que han de ser relevantes para el análisis de la función expresiva de la pena retributiva. Que la clasificación sugerida por Austin no puede estimarse satisfactoria, parece quedar claro si se indaga en la clase de acto ilocucionario a la que, en tal marco, pertenece un reproche. Esto, porque el propio Austin menciona "reproche" (blame) a propósito de dos de sus cinco tipos de ilocuciones. En primer término, Austin sugiere que el uso de blame puede, bajo determinadas condiciones, ir aparejado de la realización de un acto "comportativo", esto es, de un acto que de alguna manera consiste en una reacción frente a comportamientos de otros exhibiendo emociones y sentimientos ${ }^{133}$. En este contexto, la emisión de “yo reprocho”, por ejemplo, se encontraría en una relación de emisión realizativa (o performativa) impura frente a la emisión de "yo censuro", que sería explícitamente realizativa. Pero la emisión de "yo reprocho” también podría contar, según Austin, como la realización de un acto "veredictivo”, cuando la expresión es usada en el sentido de “declarar responsable” a alguien por algo, prescindiendo (en este contexto) de la adopción de aquellas actitudes que son determinantes cuando esa expresión aparece asociada a la realización de un acto de habla "comportativo"134.

Lo que ha de destacarse son las implicaciones que tiene la consideración de un acto de reprochar algo a alguien como un acto que, al menos desde un determinado punto de vista, aparece como una variante de "comportativo”. La nota distintiva de esta clase de actos es, según Austin, el hecho de que su fuerza ilocucionaria está asociada a la expresión de ciertas

${ }^{132}$ Así por ejemplo, Searle la ha sustituido por la diferenciación entre actos asertivos, actos compromisorios, actos directivos, actos expresivos y actos declarativos, en el entendido de que el criterio clasificatorio ha de consistir en una determinada dirección de ajuste entre lenguaje y mundo que cabe reconocer en las distintas clases de ilocuciones (Searle, John: “A Taxonomy of Illocutionary Acts”, 1979, pp. 1-29). Habermas, por su parte, sobre la base de la identificación de una determinada pretensión de validez o una determinada pretensión de poder que el hablante entabla al ejecutar un acto ilocucionario, distingue actos constativos, actos regulativos, actos expresivos y actos imperativos (Habermas, Jürgen: Teoría de la Acción Comunicativa, 1999, t. I, pp. 415417). Habermas reconoce dos clases más de actos ilocucionarios: los comunicativos y los operativos, cuya particularidad es su relación reflexiva con el proceso de comunicación, y la designación de la aplicación de reglas de construcción (lingüística), respectivamente.

133 Austin, J.L.: How to Do Things with Words, 1975, pp. 83, 160.

${ }^{134}$ Ibídem, p. 155. 
emociones, como reacción personal a comportamientos de otros. Esto determina que en este contexto se plantee, de manera especial, la cuestión de la sinceridad del hablante ${ }^{135}$. La sinceridad, en el marco del análisis de los actos ilocucionarios, designa una condición que ha de ser satisfecha para que la realización del acto sea "feliz", esto es, para que el acto sea apropiadamente realizado. La insinceridad del autor de la emisión realizativa, por ende, constituye un caso de "infelicidad", que a diferencia de otras formas de infelicidad, empero, no conlleva la invalidez o la nulidad del acto, sino que más bien constituye un abuso ${ }^{136}$. Al igual que cuando se trata de felicitaciones o condolencias, cuando se trata de un acto de reproche lo crucial es la manifestación de una emoción que el hablante tiene frente a cierto evento o suceso. Por esto, la falta de sinceridad, aun cuando no obsta a la realización del acto, sí conlleva que el acto no sea apropiado a sus circunstancias, es decir, sea desafortunado.

\section{b) La pretensión de validez subyacente al reproche}

En la reformulación de la teoría de los actos de habla efectuada por Habermas, lo anterior puede describirse en términos de que en la formulación de un reproche el hablante entabla, sin que esto sea contingente, una pretensión de sinceridad. Esto no implica que el hablante de hecho no pueda estar siendo insincero, pero sí que en este último caso se produce una instrumentalización de la comunicación. Que el autor de un reproche necesariamente entable una pretensión de sinceridad al realizar ese acto quiere decir que el reconocimiento de esta pretensión por parte del oyente es condición indispensable para el éxito ilocucionario de la emisión del hablante, en la medida en que el éxito ilocucionario puede definirse como un entendimiento, esto es, la obtención de un acuerdo entre hablante y oyente: este último ha de reconocer qué pretensión ha entablado el hablante para que así pueda tomar posición crítica de aceptación o de rechazo frente a esa pretensión ${ }^{137}$. Lo que cuenta como la realización de ese acto de habla depende, entre otras cosas, de que el oyente reconozca esa pretensión de validez.

Ciertamente, lo anterior no significa que al formularse un reproche sólo se entable una pretensión de sinceridad. Pues si se deja de lado la distinción, que en todo caso es analíticamente fecunda, entre casos puros

135 Ibídem, pp. 78-79, 161.

${ }^{136}$ Ibídem, pp. 12-18, 39-47.

${ }^{137}$ Habermas, Jürgen: Teoría de la Acción Comunicativa, 1999, t. I, pp. 379396. Véase también Habermas, Jürgen: “¿Qué Significa Pragmática Universal?”, 1989, pp. 350-365. 
(idealizados) de actos de habla según la pretensión de validez que determina su fuerza ilocucionaria, es claro que en todo acto de habla orientado al entendimiento han de entenderse entabladas las tres pretensiones de validez con arreglo a las cuales Habermas efectúa la clasificación entre los casos puros de actos constatativos, actos regulativos y actos expresivos: una pretensión de verdad, una pretensión de rectitud (corrección o adecuación) y una pretensión de sinceridad ${ }^{138}$.

Esto ha de resultar suficientemente claro en el caso de un reproche. Desde ya, en tanto el reproche tiene como objeto, típicamente, un comportamiento por el cual alguien es responsable, el hablante necesariamente tiene que presuponer, para que el reproche pueda ser aceptado, la efectividad de estas circunstancias. El éxito ilocucionario de un reproche también está condicionado, por ende, por una pretensión de verdad, a saber, la pretensión de verdad relativa a lo que constituye el contenido proposicional del reproche en cuestión ${ }^{139}$. Pero, además, la fuerza ilocucionaria de un reproche no sólo está determinada por una condición de sinceridad, de acuerdo a lo ya discutido, sino que también está asociada a la identificación de un determinado horizonte normativo en el marco del cual el reproche conlleva una pretensión de corrección. Al reprocharse a otro haber actuado de determinada manera, necesariamente se presuponen normas bajo las cuales el acto reprochado ha de aparecer como incorrecto o censurable. Es precisamente esta dependencia del reproche respecto de un determinado horizonte normativo que lo valida lo que aparecía en la insinuación de la indignación moral como emoción subyacente al reproche penal, que hace posible diferenciarla, por ejemplo, de un ánimo de venganza.

Bajo una justificación retribucionista de la pena, su imposición ha de ser entendida como un acto de expresión de reproche merecido. La formulación de un reproche penal, por ende, puede ser vista como la realización de un acto ilocucionario, y más específicamente, como un acto ilocucionario institucionalmente ligado. Lo que distingue a esta clase de actos de habla es el hecho de que la explicación de lo que cuenta como su ejecución requiere de una referencia a ciertas instituciones ${ }^{140}$, que en este caso son las instituciones jurídicas del sistema penal. Una de las implicaciones de

${ }^{138}$ Habermas, Jürgen: Teoría de la Acción Comunicativa, 1999, t. I, pp. 407419.

${ }^{139}$ En la terminología de Habermas, ello conlleva una caracterización de ese acto de habla como "proposicionalmente diferenciado” (Habermas, Jürgen: “¿Qué Significa Pragmática Universal?”, 1989, p. 337). La distinción entre el contenido proposicional y la fuerza ilocucionaria en el análisis de los actos de habla es lo que constituye lo que Habermas denomina la "doble estructura del habla” (ibídem, pp. 341-344).

${ }^{140}$ Ibídem, p. 338. 
que el acto de reproche penal sea institucionalmente ligado es que esta ligazón institucional circunscribe sus posibles contenidos proposicionales: por ejemplo, en el sentido de que sólo un comportamiento evitable que satisface una determinada descripción fijada en la ley puede ser objeto de reproche penal. La cuestión que debe examinarse ahora es por qué la expresión de este reproche ha de materializarse en la irrogación de un mal, en circunstancias que para la expresión de reproche podría parecer suficiente una mera declaración simbólica. Si esto último fuese suficiente, la ejecución de la pena tendría que considerarse injustificada, en tanto excesiva.

\section{c) La relación entre la irrogación del mal y la expresión de reproche}

Un intento de disociar la dimensión expresiva de la pena de su facticidad como irrogación de un mal es lo que se encuentra en la teoría de la pena de Andrew von Hirsch ${ }^{141}$. Siguiendo a Feinberg y Strawson, von Hirsch sostiene que es imposible dar cuenta de lo que significa la pena si se pierde de vista el componente expresivo de determinadas actitudes reactivas. El punto está, sin embargo, en que bajo la sola consideración de la expresión de un reproche merecido no podría justificarse la irrogación de un mal como algo que tiene lugar adicionalmente al acto de reproche mismo. $\mathrm{Si}$ la irrogación del mal ha de reconocerse como un elemento independiente, su justificación tiene que basarse en una razón distinta. Lo único que podría justificar la irrogación del mal en que se materializa la pena, según von Hirsch, sería la prevención de delitos futuros ${ }^{142}$. Von Hirsch reconoce que entonces podría emerger, como siempre ocurre cuando se esgrime una justificación prevencionista de la pena, la objeción kantiana de que el condenado no es tratado como un fin en sí mismo, sino como un medio para fines ajenos. La objeción sería neutralizada, sin embargo, por el componente expresivo-retributivo, que garantiza que el comportamiento que da lugar a la punición sea un comportamiento censurable del cual el sujeto es responsable ${ }^{143}$.

El paso en falso que da von Hirsch se encuentra en la suposición de que es posible, en definitiva, diferenciar el momento expresivo de reproche

${ }^{141}$ Hirsch, Andrew von: Past or Future Crimes, 1985, pp. 47-60. Esta toma de posición supone un distanciamiento frente a trabajos previos del propio von Hirsch en que éste defendía una concepción puramente retribucionista de la función de la pena (véase Hirsch, Andrew von: Doing Justice, 1976).

142 Hirsch, Andrew von: Past or Future Crimes, 1985, pp. 51-54. Esta tesis encuentra cierto apoyo en Feinberg, Joel: “Justice and Personal Desert”, 1970, p. 83.

${ }^{143}$ Hirsch, Andrew von: Past or Future Crimes, 1985, pp. 55-56. 
frente a la mera irrogación del mal en que consiste la (ejecución de la) pena. Pues el propio Feinberg, a pesar de reconocer la plausibilidad de la distinción conceptual entre ambos componentes, mantiene que lo apropiado es entender que la irrogación del mal es la manera de expresar la reprobación, siendo este aspecto expresivo de la irrogación del mal lo que posibilita concebirlo como punishment, y no como (mera) penalty ${ }^{144}$. A este respecto, es pertinente volver atrás para considerar nuevamente el tipo de ilocución en que Austin propone clasificar a los actos de reproche. Según ya se vio, habría un cierto punto de vista desde el cual la fuerza ilocucionaria desplegada en un reproche lo acercaría a los "veredictivos", mientras que desde otra perspectiva el reprochar algo a alguien parecería acercarse a los "comportativos". Lo primero ocurre, siguiendo a Austin, en tanto lo enfatizado sea la declaración del finding de culpabilidad, o sea, el veredicto o — tratándose de un tribunal de derecho- fallo. Mas no es éste el punto de vista desde el cual aparece destacado el aspecto del reproche que se corresponde con la manifestación de determinadas emociones de decepción o resentimiento. Este aspecto es el que distingue al reproche como un acto que se entiende como reacción frente a un acto o comportamiento ajeno, o sea, como un acto de habla "comportativo". Es en este sentido que Strawson caracteriza el modo de expresar una actitud reactiva como la suspensión, más o menos extensa o intensa, de una disposición generalmente favorable hacia aquel que es destinatario de la expresión de reproche ${ }^{145}$.

La irrogación del mal, entonces, no es más que la materialización de esta suspensión de la disposición favorable que toda persona tiene respecto de otro a quien considera un alter ego moral. Es de esta manera que tiene lugar la expresión del reproche merecido, y no a través de una declaración, como el veredicto o la determinación de culpabilidad. Esta última no constituye la expresión del reproche, sino más bien una condición procedimental necesaria de su merecimiento. La irrogación de un mal es el modo por el cual tiene lugar la expresión de reproche porque, a diferencia de lo que se da en situaciones de relaciones personales de intimidad o cercanía, el reproche penal tiene lugar en un contexto social de contactos anónimos, en el cual una mera declaración de reproche no alcanza a materializar un reproche. En un contexto social donde no todo es asunto de todos, una mera declaración de reproche pudiera padecer, tal como lo sugería Jakobs, de un déficit de objetivación. Puesto en terminología hegeliana: así como el delito es la objetivación de una voluntad particular cuyo valor declarativo es la lesión del derecho en cuanto derecho, la pena retributiva ha de consistir en la objeti-

\footnotetext{
${ }^{144}$ Feinberg, Joel: “The Expressive Function of Punishment”, 1970, p. 99.

${ }^{145}$ Strawson, P.S.: Libertad y Resentimiento, 1995, p. 63.
} 
vación de una voluntad (general) de cancelación de esa voluntad, que constituye el restablecimiento del derecho ${ }^{146}$.

De lo que se trata es de advertir, entonces, que declarar que se reprocha puede no equivaler a efectuar un reproche, tal como decir "te insulto" no constituye un insulto: ni "insultar" ni "reprochar" cuentan como verbos explícitamente performativos. Esto no excluye, ciertamente, la posibilidad de que una declaración de culpabilidad pudiera, bajo ciertas condiciones, expresar adecuadamente un reproche punitivo. Lo que habría que reconocer, sin embargo, es que, bajo tales condiciones, esa declaración ya tendría que contar como la irrogación de un mal. Que esto es posible lo muestra, de modo suficientemente plástico, la tipificación penal de delitos contra el honor ${ }^{147}$.

Que la expresión del reproche penal, por ende, tenga lugar de modo no-verbal, no obsta a que la imposición de la pena cuente como la realización de un acto de habla, pues como Austin mismo lo advierte, puede haber varios mecanismos convencionales, también no-verbales, para la realización de actos de habla, notablemente tratándose de actos ilocucionarios institucionalmente ligados ${ }^{148}$. Y esto es precisamente lo que afirma Feinberg cuando dice que nuestras convenciones pueden determinar que el hard treatment sea el modo de expresar desaprobación. Disponer de estas convenciones, fijadas institucionalmente, hace posible ver la punición como una institucionalización de la expresión del reproche merecido. Al institucionalizarse este modo de formulación de reproche, por lo demás, se vuelve irrelevante si quien formula el reproche efectivamente es portador, psicológicamente hablando, de los estados mentales que definen a aquellas actitudes reactivas que dan lugar a que se reproche algo a otro ${ }^{149}$.

Pero es crucial enfatizar el carácter convencional de la ligazón entre la expresión de reproche y la irrogación del mal. Que se trate de una conexión convencional implica, entre otras cosas, que se trata de una conexión contingente. $\mathrm{Y}$ esto quiere decir que es enteramente posible pensar en otros símbolos convencionales para la expresión institucional del reproche ${ }^{150}$.

${ }^{146}$ Hegel, G.W.F.: Grundlinien der Philosophie des Rechts, 1970, §§ 97, 99.

${ }^{147}$ Para una reconstrucción dogmática de los delitos de calumnia e injuria como actos ilocucionarios, Mañalich, Juan Pablo: “¿La Comisión de Delitos mediante la Imputación de Delitos? Los Delitos contra el Honor bajo la Teoría de los Actos de Habla”, 2005.

148 Austin, J.L.: How to Do Things with Words, 1975, pp. 119-121.

${ }^{149}$ Véase Feinberg, Joel: “Justice and Personal Desert”, 1970, pp. 67-69.

${ }^{150}$ Véase Günther, Klaus: "Die symbolische-expressive Bedeutung der Strafe”, 2002, pp. 217-219, quien sugiere la posibilidad de sustitución de la pena por otras reacciones con igual rendimiento expresivo, lo cual en definitiva supone identificar la noción de pena con la irrogación de un mal. Véase también, Pawlik, Michael: Person, Subjekt, Bürger. Zur Legitimation von Strafe, 2004, pp. 66-69. 


\section{II.2. La pena retributiva, el ius talionis y la víctima}

\section{a) La configuración institucional del reproche penal}

Feinberg reconoce la plausibilidad de una propuesta de sustitución de los males que ordinariamente conforman el catálogo de penas de los sistemas jurídicos contemporáneos por la implementación de otra clase de mecanismos rituales a través de los cuales pudiera, en principio, obtenerse un medio igualmente idóneo para la expresión de desaprobación. Pero, agrega Feinberg, en tal caso no habría que perder de vista la naturaleza de la cuestión que estaría discutiéndose: se trataría de una discusión acerca de la justificación de nuestros actuales símbolos de infamia ${ }^{151}$. O sea, aquello que por definición parece constituir el aspecto estructural de la noción de pena se encuentra supeditado a la satisfacción de su función expresivoretributiva. Esto hace posible retomar la tesis de Moore acerca del derecho penal como una clase o categoría funcional, determinada por una función retributiva. Si el derecho penal constituye una clase funcional, lo que cuenta como una instancia particular de esa clase, esto es, la imposición de una pena, tiene que satisfacer esa función. Esto significa que la irrogación del mal debe constituir un modo idóneo de expresión de un reproche merecido. La pregunta que cabe plantear entonces se refiere a los criterios de acuerdo con los cuales puede establecerse qué medida de pena resulta adecuada a la medida del reproche merecido.

En este marco cabe situar una objeción tradicionalmente dirigida a las propuestas de justificación retribucionista de la pena, la cual consiste en que la pena retributiva necesariamente tendría que operar de acuerdo con la ley del talión. Una concepción de la pena retributiva en el sentido de la ley del talión supone entender la noción de retribución como una cierta compensación de un mal con otro mal equivalente, en circunstancias que el mal de cuya compensación se trata es el daño causado por el autor del delito: si se trata de un asesinato, el autor tendría que ser asesinado; si se trata de una mutilación, el autor tendría que ser mutilado, etc. Así presentado, el principio del talión carece de sentido ${ }^{152}$.

${ }^{151}$ Feinberg, Joel: “The Expressive Function of Punishment”, 1970, pp. 115116.

152 Esto no significa que no haya formulación más plausible del principio del talión. Jeremy Waldron, por ejemplo, sugiere que el principio del talión debería concebirse como la exigencia de que el acto de la punición posea algunas de o todas las características del comportamiento punible que determinan el carácter incorrecto de éste. Waldron sostiene, empero, que los términos en que pueden ser descritas esas características pueden 
El defecto del argumento radica, sin embargo, en el desconocimiento de que la medida de la irrogación del mal en que consiste la pena no puede establecerse en el nivel de referencia del daño empírico que puede seguirse de la comisión de un delito, pues de lo contrario sería la irrogación del mal, como hecho puramente bruto, lo que constituiría el núcleo de la imposición de la pena ${ }^{153}$. La irrogación del mal, sin embargo, sólo constituye la materialización del reproche merecido, por lo cual es de conformidad con la medida del reproche que ha de fijarse la pena cuya imposición y ejecución es retributivamente apropiada ${ }^{154}$. Es como hecho institucional y no como hecho bruto que la irrogación del mal ha de corresponderse con el delito. Y puesto que, siguiendo a Kindhäuser, y en definitiva a Kant ${ }^{155}$, el delito se constituye como la contradicción de una norma de comportamiento de cuyo cumplimiento generalizado por parte de otros el autor se aprovecha injustamente, la medida del reproche ha de corresponder a la medida del quebrantamiento de la norma, lo cual depende tanto de cuál sea esa norma (compárese un delito de asesinato con un delito de apropiación de cosas ajenas), como de cuál sea la forma de responsabilidad del sujeto por la realización del comportamiento (compárese un delito intencional o doloso con un delito negligente o imprudente). Es la falta de sentido de la justicia que el comportamiento delictivo expresa, o sea, la defraudación de la confianza depositada ex ante en el autor como co-agente moral, lo que constituye el objeto del reproche que se expresa en la pena retributiva ${ }^{156}$.

ser más o menos abstractos, de modo que, por ejemplo, lo que determina el carácter incorrecto de una violación no tiene por qué ser descrito, necesariamente, connotando la mediación sexual del acto, sino que puede consignarse atendiendo al trauma y la vulneración de la dignidad de la víctima (Waldron, Jeremy: “Lex Talionis”, 1992, pp. 32-37). Quizá más llamativo todavía sea el hecho de que Waldron sostenga que el principio del talión es compatible con distintas teorías de la justificación de la pena, en modo alguno siendo privativa de las teorías de la retribución (ibídem, pp. 26-32). Lo crucial es que Waldron reconozca que la suya es una versión bastante relajada del principio del talión, ante lo cual la pregunta tendría que apuntar a cuánto relajo resiste tal principio antes de convertirse en algo distinto.

${ }^{153}$ Véase Hegel, G.W.F.: Grundlinien der Philosophie des Rechts, 1970, § 101.

${ }^{154}$ Feinberg, Joel: “The Expressive Function of Punishment”, 1970, pp. 116118. Esto lo desconoce Kenny, cuando afirma que el elemento esencial de la pena, de conformidad con una teoría de la retribución, sería la irrogación de un daño al penado (Kenny, Anthony: Freewill and Responsibility, 1978, p. 73).

${ }^{155} \mathrm{La}$ idea de que el autor del delito se aprovecha injustamente del cumplimiento generalizado de normas justas para todos es lo que estaría en el centro de la teoría kantiana de la pena de conformidad con Murphy, Jeffrie: "Kant’s Theory of Criminal Punishment”, 1979, p. 83.

${ }^{156}$ Kindhäuser, Urs: “Personalität, Schuld und Vergeltung”, 1989, p. 504. 


\section{b) La víctima y el proceso penal}

Si el reproche penal se sitúa, correctamente, en el plano del quebrantamiento de la norma, y no en el daño empíricamente causado por el comportamiento delictivo, es claro que la retribución no sólo no exige el principio del talión, sino que lo excluye. Por la misma razón, el reproche penal no se formula desde el punto de vista de la víctima del delito: el fundamento del reproche se encuentra en la defraudación de la confianza recíproca que se reconocen los co-agentes morales respecto del seguimiento de normas aceptables para todos, y no (directamente) en la lesión de un bien jurídico (aun cuando ésta puede condicionar parcialmente, la medida del reproche). El reproche penal es un asunto público, y por eso el derecho penal es derecho público.

A este respecto, es suficientemente ilustrativo el debate que en la teoría penal norteamericana se produjera en torno a los movimientos pro “derechos de las víctimas”. Quizá el caso más notable sea el giro hacia la víctima dado por un otrora convencido retribucionista, Jeffrie Murphy. En el marco de una revisión crítica de su propia articulación previa de una teoría retribucionista, Murphy se muestra partidario de un cierto grado de institucionalización de venganza por parte de la víctima ${ }^{157}$. Lo fundamental es el reconocimiento explícito por parte de Murphy de que tal giro necesariamente conlleva un debilitamiento de la justificación propiamente retribucionista de la reacción penal. Tal como Murphy lo sugiere, para la admisibilidad de tal institucionalización de expresiones de venganza bastaría con reformular el merecimiento de pena como una exigencia puramente limitativa, entendiéndolo como una restricción, y no como la razón positiva, para la imposición de la pena. Pues entonces la reacción punitiva podría venir apoyada, también, por consideraciones de venganza relativas a la víctima del delito en cuestión ${ }^{158}$.

Lo que Murphy sugiere, entonces, es que bajo una concepción propiamente retribucionista de la pena, de la cual él ha tomado distancia, la víctima no puede tener injerencia en la definición de si ha de imponerse pena y de cuánta pena ha de ser impuesta. Esto tiene consecuencias para la articulación retribucionista de la estructura del proceso penal. Tal como Moore lo ha puesto de manifiesto en una de sus tantas polémicas con George Fletcher, la retribución exige que la víctima sea ignorada en el diseño del procedimiento penal ${ }^{159}$. Esto no significa que la víctima sea irrelevante

${ }^{157}$ Murphy, Jeffrie: “Getting Even: The Role of the Victim”, 1992, pp. 61-85.

${ }^{158}$ Ibídem, p. 83.

${ }^{159}$ Moore, Michael: "Victims and Retribution: A Reply to Professor Fletcher", 2000, pp. 66 ss. 
desde un punto de vista sustantivo referido a la constitución del objeto de reproche penal. El principio de retribución justifica la imposición de la pena en atención al solo merecimiento de reproche, cuya determinación resulta del quebrantamiento de una norma por un comportamiento. La noción de quebrantamiento de la norma comprende tanto las condiciones del carácter incorrecto o prohibido del comportamiento (condiciones del wrongdoing) como las condiciones de la responsabilidad individual por el comportamiento (condiciones de la culpability) ${ }^{160}$. Según Moore, la víctima (sólo) es relevante desde el punto de vista de la estructura de la norma cuyo quebrantamiento es merecedor de reproche. Si el derecho penal se ajusta a la descripción de un sistema de normas moralmente aceptables, el núcleo de las normas de comportamiento penalmente reforzadas está constituido por normas que imponen deberes, a los cuales corresponden derechos correlativos. La infracción del deber en que se concreta la norma se corresponde con la lesión de un derecho correlativo, siendo la víctima el titular de este derecho ${ }^{161}$. Si estas normas confieren derechos, entonces se trata de normas relativas-a-la-víctima. Y por eso, en el ámbito de delitos que se corresponden con la violación de esta clase de derechos subjetivos, dependiendo de cuántas víctimas haya, se computa una igual cantidad de quebrantamientos de la norma ${ }^{162}$.

Nada de esto implica, sin embargo, que a la persona de la víctima haya de conferirse algún estatus especial en la determinación del reproche merecido por el quebrantamiento de la norma. En este sentido, la víctima tiene el mismo derecho a participar en la definición democrática de los juicios abstractos de merecimiento de pena que cualquier otro ciudadano, y nada más ${ }^{163}$. Conferir a la víctima un estatus preferente para la definición del juicio concreto acerca de la imposición de la pena supondría diluir la distinción entre exigencias de justicia retributiva y exigencias de justicia correctiva. El derecho penal es el derecho de la justicia retributiva, y en esta

${ }^{160}$ Ibídem, p. 69. Véase también Nozick, Robert: Philosophical Explanations, 1981, pp. 363-365, 388-390. El wrongdoing puede no constituir una condición necesaria del reproche penal, en tanto la tentativa sea objeto de reproche penal. En la tentativa hay un quebrantamiento de la norma, pero el comportamiento no satisface la descripción de la conducta prohibida por la norma.

${ }^{161}$ Ibídem, pp. 70-71.

162 Ibídem. Ésta es una consideración crucial para la teoría de los concursos de delitos, y en particular para lo que en la doctrina penal continental se conoce como concurso ideal homogéneo. En tales casos, ciertamente, hay varias realizaciones típicas, y esto significa, varias instancias de comportamiento antinormativo (tratándose de prohibiciones de resultados lesivos, tantas como resultados lesivos), mas en circunstancias tales que las realizaciones típicas tienen lugar en unidad de acción.

163 Ibídem, pp. 75, 89. 
medida el proceso penal es el proceso de realización de la justicia retributiva. Nuevamente en términos hegelianos: a través del proceso judicial, la realización de la justicia retributiva es asumida, institucionalmente, como cometido de la generalidad ${ }^{164}$.

En el marco de un Estado democrático de derecho, es al legislador a quien compete la determinación de la entidad y el quantum de las penas a través de cuya imposición ha de manifestarse el reproche que la contradicción de una norma de comportamiento merece. El punto está en que si el legislador pretende sentar las bases normativas para un reproche penal, el mismo debe respetar las relaciones de proporcionalidad que cabe reconocer en nuestras actitudes reactivas frente a comportamientos que desaprobamos. Usando la terminología de von Hirsch ${ }^{165}$, estas relaciones de proporcionalidad han de verse expresadas en las magnitudes ordinales y cardinales de determinación legal de la pena, esto es, en las medidas de pena que han de ser respetadas tanto considerando la gravedad relativa de cada (clase de) delito frente a otros, como la escala absoluta de severidad de las penas a ser utilizada, respectivamente. Establecer, por ejemplo, un mismo marco penal para la punición de un homicidio y de un robo implica desconocer esos patrones de proporcionalidad.

\section{II.3. La pena retributiva como acción comunicativa: el reproche como reconocimiento}

a) Acción comunicativa y acción estratégica

La reconstrucción de la función expresivo-retributiva de la pena en el marco de la teoría de los actos de habla lleva consigo la tesis de que el autor del reproche penal sólo persigue el éxito ilocucionario de su acto de habla, lo que equivale a decir que el autor del reproche manifiesta una orientación al entendimiento para con el destinatario del reproche. En las categorías desarrolladas por Habermas, esto significa que el reproche penal, retributivamente fundado, constituye un caso de acción comunicativa ${ }^{166}$. La cuestión que debe examinarse ahora es la relación que puede establecerse entre esta concepción comunicativa de la pena y sus posibles efectos preventivos. Desde el punto de vista de una justificación retribucionista de la pena, es obvio cuál ha de ser el estatus de los posibles efectos preventivos que

\footnotetext{
${ }^{164}$ Hegel, G.W.F.: Grundlinien der Philosophie des Rechts, 1970, § 220.

${ }^{165}$ Hirsch, Andrew von: Past or Future Crimes, 1985, pp. 38-46.

${ }^{166}$ Habermas, Jürgen: Teoría de la Acción Comunicativa, 1999, t. I, p. 378.
} 
pueden seguirse de la imposición de la pena: se trata, a lo sumo, de consecuencias favorables no perseguidas, una instancia de lo que los economistas consideran externalidades positivas. Que la imposición de la pena pueda de hecho conllevar tales efectos en modo alguno supone que la imposición de la pena se justifique en atención a ellos: la justificación de la pena retributiva sólo descansa en un juicio de merecimiento ${ }^{167}$.

En el marco de la teoría de los actos de habla, si el acto ilocucionario del reproche penal se orientara a la producción de tales consecuencias preventivas, éstas constituirían efectos perlocucionarios de ese acto. Un efecto perlocucionario de un acto de habla es la consecuencia que la realización de ese acto tiene en el oyente, por ejemplo, el efecto intimidante que una amenaza tiene en el amenazado. Lo crucial es advertir el carácter contingente de la relación que existe entre el acto ilocucionario y su respectivo efecto perlocucionario: una amenaza (acto ilocucionario) no deja de ser tal por el solo hecho de que su destinatario no resulte, efectivamente, intimidado (efecto perlocucionario). Mientras que la fuerza ilocucionaria del acto se da si una determinada locución se emite en las circunstancias apropiadas, la producción del efecto perlocucionario eventualmente perseguido por el hablante es puramente contingente, en el sentido de que ella no depende de la sola realización exitosa del acto ilocucionario ${ }^{168}$.

El punto está en que si el hablante persigue la producción de tales efectos perlocucionarios, aquél ya no se orienta al entendimiento con el oyente, esto es, a la obtención de un acuerdo que depende del reconocimiento por parte de éste de las pretensiones de validez que el hablante reclama para su acto de habla. La interacción lingüísticamente mediada en que el autor persigue la producción de efectos perlocucionarios en el oyente no cuenta como acción comunicativa, sino como acción estratégica ${ }^{169}$. La imposición de la pena orientada a la consecución de efectos preventivos, por ende, constituye un caso de acción estratégica. A este respecto, es irrelevante que el destinatario de ese acto de habla sea el propio sujeto sancionado, en términos de prevención especial, o la generalidad de los individuos, en términos de prevención general. Lo que en todo caso ocurre es que quien impone la pena no se orienta, de este modo, a entenderse con otro, sino a la obtención de consecuencias que son sólo contingentes frente al reproche de culpabilidad, el cual de este modo resulta falseado.

\footnotetext{
${ }^{167}$ Moore, Michael: Placing Blame, 1997, p. 153.

${ }^{168}$ Habermas, Jürgen: Teoría de la Acción Comunicativa, 1999, t. I, pp. 371375.

169 Ibídem, pp. 375-378.
} 
Esto muestra que las bases pragmáticas de la imposición de la pena son radicalmente distintas cuando la punición se fundamenta retributivamente y cuando ella se fundamenta preventivamente. La punición retributiva constituye un caso de acción comunicativa, que se corresponde con la adopción de la perspectiva del participante en la comunicación con otros, mientras que la punición preventiva constituye, en principio, un caso de acción estratégica, que se corresponde con la adopción de la perspectiva del observador no vinculado a la práctica comunicativa. Sólo la primera articulación es congruente con la adopción de una actitud reactiva frente a otro que es reconocido como un co-agente moral. La segunda, en cambio, se corresponde con la adopción de una actitud objetivante, aquella bajo la cual el otro aparece como objeto de táctica social. La punición preventivamente orientada inevitablemente conlleva la instrumentalización del (que es declarado) culpable ${ }^{170}$.

La persecución de efectos preventivos a través de la imposición de la pena vuelve imposible que ésta pueda entenderse como la expresión de un reproche, pues un reproche, como actitud reactiva, no admite ser usado para la obtención de una consecuencia ulterior, ya que la formulación de un reproche presupone sinceridad en cuanto a las razones que lo justifican. En caso contrario, el reproche no deja de ser una pura ficción. Si la búsqueda de efectos preventivos tiene lugar a través de la imposición de una pena que se hace pasar como la expresión de un reproche, esta ficción de un reproche orientada a la producción de efectos perlocucionarios, o sea, esta acción estratégica encubierta, constituye un caso de lo que Habermas denomina una distorsión de la comunicación ${ }^{171}$.

\section{b) Acción estratégica y acción instrumental}

Hay que precisar que la descripción de la imposición de una pena preventiva como un caso de acción estratégica es acertada sólo en relación con una teoría de la prevención de intimidación, ya sea general o especial. Tratándose de otras variantes de prevención especial, la descripción no funciona. Si la pena se entiende como una medida impuesta para la educa-

${ }^{170}$ Sobre esto, Kindhäuser, Urs: "La Fidelidad al Derecho como Categoría de la Culpabilidad”, 2000, pp. 207-213. A esto no se opone el hecho de que una acción orientada al entendimiento también pueda ser descrita como acción orientada a fines, en el sentido de que el fin perseguido por el actor sea, precisamente, entenderse con otro (véase Baurmann, Michael: Zweckrationalität und Strafrecht, 1987, pp. 56 ss.).

${ }^{171}$ Habermas, Jürgen: Teoría de la Acción Comunicativa, 1999, t. I, pp. 425426. 
ción, la resocialización o el tratamiento terapéutico del penado, la imposición de la pena pierde toda connotación expresiva, lo cual da cuenta de la dificultad de compatibilizar una concepción semejante de la función de la pena con nuestra noción intuitiva de lo que significa “pena”. Lo mismo puede decirse acerca de la prevención especial de neutralización. Considérese al efecto el suficientemente ilustrativo pasaje tomado de un célebre defensor de la teoría de la prevención especial, Franz von Liszt:

Pero la pena puede tener también como misión suprimir, perpetua o temporalmente, al criminal que ha llegado a ser inútil a la comunidad, la posibilidad física de cometer nuevos crímenes, separándole de la Sociedad (selección artificial). Aquí se trata de la INOCULIZACIÓN [...] del delincuente ${ }^{172}$.

Lo crucial es que, en todo caso, se trata de una intervención sobre el "penado” que se encuentra libre de toda mediación lingüística. En la terminología de Habermas, lo que esas teorías conllevan es una concepción de la imposición de la pena como un caso de acción puramente instrumental: aquí ni siquiera cabe reconocer una utilización estratégica de la comunicación, pues no hay comunicación alguna ${ }^{173}$. Si el componente expresivo de la pena es en todo caso irrenunciable, estas teorías de la prevención especial sólo pueden constituir teorías acerca de la imposición de medidas de seguridad.

\section{c) Inclusión y exclusión: ¿el delincuente como enemigo?}

La justificación retributiva de la pena es la única que da cuenta, de modo consistente, de las presuposiciones pragmáticas implicadas en la formulación del reproche penal. El reproche supone la adopción de una actitud reactiva, y el reproche se formula asumiendo la perspectiva de un participante en la comunicación. Esto implica que el autor del reproche reconoce al destinatario de éste como un participante en la comunicación. La imposición de la pena retributiva conlleva un reconocimiento del sujeto sancionado ${ }^{174}$. La paradoja del reproche expresado en la pena se encuentra en que el reproche constituye un reconocimiento cuyo sentido es la desaprobación: la paradoja está en que reconocemos al autor, mediante el reproche de culpa-

\footnotetext{
172 Liszt, Franz von: Tratado de Derecho Penal, 1999, t. ii, p. 10.

173 Habermas, Jürgen: Teoría de la Acción Comunicativa, 1999, t. I, pp. 366-

367.

${ }^{174}$ Feinberg, Joel: “Justice and Personal Desert”, 1970, pp. 69-70.
} 
bilidad, como un participante en la interacción comunicativa ${ }^{175}$. Que en esta desaprobación hay un reconocimiento se sigue necesariamente de la suposición de que el reproche y la pena deben ser merecidos, que es el núcleo de la exigencia de culpabilidad. La pena puede verse, como sugiere Walzer, como un honor negativo ${ }^{176}$. $\mathrm{Y}$ es precisamente esto lo que subyace a la tesis hegeliana de que el autor del delito tiene derecho a la pena ${ }^{177}$.

Como se verá más abajo, la relación entre retribución y ciudadanía es una relación fuerte, pues la legitimidad política del reproche de culpabilidad sólo puede seguirse del hecho de que el autor del quebrantamiento de la norma pueda ser también visto como autor de esa norma. El reproche penal sólo es legítimo en tanto tiene lugar entre ciudadanos vinculados por normas comunes. Lo que ahora interesa es indagar en las implicaciones de una sugerencia en cierto sentido contraria, a saber, la sugerencia de que la imposición de la pena pudiera conllevar la marginación del individuo penado respecto de la comunidad políticamente organizada. Esto aparece con claridad en la teoría de la pena de Fichte, quien, sobre la base de un modelo contractualista del fundamento de la ley penal, entiende que el "contrato de ciudadanía” incorpora una condición elemental: “Todos los derechos positivos que posee el ciudadano sólo los posee a condición de que los derechos de todos los otros ciudadanos estén seguros ante él”, en términos tales que "[t]odo delito excluye del Estado (el criminal se convierte en proscrito, es decir que su seguridad está tan poco garantizada como la de un pájaro, ex lex, hors de loi)”178.

Lo importante es advertir qué consecuencias se siguen de la declaración de privación de derechos, que equivale a la exclusión absoluta del Estado. En la concepción de Fichte, esto se da siempre que es imposible alcanzar el fin que persigue el ejercicio del poder estatal, que es asegurar las

${ }^{175}$ Kindhäuser, Urs: "La Fidelidad al Derecho como Categoría de la Culpabilidad”, 2000, p. 210.

${ }^{176}$ Walzer, Michael: Las Esferas de la Justicia, 1993, pp. 278-280, 282.

177 Hegel, G.W.F.: Grundlinien der Philosophie des Rechts, 1970, § 100; Pawlik, Michael: Person, Subjekt, Bürger, 2004, p. 97. Feinberg sostiene que la suposición de que el autor del delito pudiera tener un derecho a la pena se funda en una confusión entre promesas y amenazas condicionales. El destinatario de una promesa tendría un derecho a lo prometido si se cumple la condición correspondiente, mientras que difícilmente podría afirmarse que el destinatario de una amenaza tenga un derecho al cumplimiento de lo amenazado. Feinberg entiende que el anuncio de la imposición de la pena subordinada a la realización de un comportamiento se parece más a una amenaza que a una promesa. Pero esto no obsta a la posibilidad de mirar la amenaza de pena como una promesa invertida: si no se cumple la condición, que depende del destinatario de la amenaza, éste sí tiene derecho a que no se le imponga la pena (Feinberg, Joel: “Justice and Personal Desert”, 1970, p. 73, nota 19).

${ }^{178}$ Fichte, J.G.: Fundamentos de Derecho Natural, 1994, p. 316. 
condiciones de seguridad recíproca, por una vía distinta de la exclusión del Estado. A contrario, sin embargo, en la medida en que la seguridad pública no resulte amenazada, es posible no imponer la exclusión "de la que es en rigor merecedor todo delito”, sobre la base de lo que Fichte denomina contrato de expiación: "todos prometen a todos, en la medida en que es compatible con la seguridad pública, no excluirles del Estado por sus delitos, sino permitirle expiar esta pena de otra manera"179 . Pero no puede descartarse que en ciertos casos la sujeción al contrato de expiación resulte incompatible con el fin del Estado. Según Fichte, esto se daría en dos grupos de situaciones: primero, sin que se practique una prueba provisional orientada a la corrección del sujeto, ya sea porque se trata de un asesino (pues el asesinato intencional y premeditado es "el único crimen contra el que el esfuerzo por mejorar al criminal no ha ya a lugar”) o porque el sujeto no quiere someterse a prueba (pues la expiación sería objeto de un derecho renunciable); y segundo, tras haberse fracasado en esa prueba provisional ${ }^{180}$. En una situación en que el vínculo entre el ciudadano y el Estado se ha disuelto, por resultar imposible garantizar la seguridad a través de la expiación, afirma Fichte, aquél ya no es ciudadano y éste ya no es Estado, de modo que la situación está fuera del alcance del derecho. Aquí ya no hay lugar para la expiación ni, en general, para la pena, en términos tales que la intervención sobre el exonerado sólo puede concebirse como una medida de seguridad $^{181}$.

Esta indagación es importante, si se vincula a la constatación, hecha por Jakobs, de que para Fichte "todo delincuente es de por sí un enemigo"182. La intervención sobre un individuo al cual se priva de la ciudadanía, o bien de las posibilidades de tomar parte en la vida política de la comunidad asociadas a la condición de ciudadano ${ }^{183}$, no es, de este modo, propia de un modelo de derecho penal del ciudadano, sino más bien de un modelo de derecho penal del enemigo, o sea, "guerra refrenada"184. Si la reacción

179 Ibídem, p. 317.

180 Ibídem, p. 330.

${ }^{181}$ Ibídem, pp. 331-332.

182 Jakobs, Günther: "Derecho Penal del Ciudadano y Derecho Penal del Enemigo", 2003, p. 29.

${ }^{183}$ Críticamente acerca de la privación del derecho a voto de los condenados en los EE.UU., Lippke, R.L.: “The Disenfranchisement of Felons”, 2001, pp. 553 ss.; Cholbi, Michael: “A Felon’s Right to Vote”, 2002, pp. 543 ss. Acerca del problema en el derecho chileno, Mañalich, Juan Pablo: "Pena y Ciudadanía”, 2005, pp. 63-83.

${ }^{184}$ Véase Jakobs, Günther: "Derecho Penal del Ciudadano y Derecho Penal del Enemigo”, 2003, p. 42. Para una primera formulación del concepto de derecho penal del enemigo, véase Jakobs, Günther: "Criminalización en el Estadio Previo a la Lesión de un Bien Jurídico”, 1997, pp. 293-324. 
estatal conlleva la exclusión del autor del delito de la comunidad política, ella no puede constituir una pena, pues habiéndose disuelto el derecho, no es posible que en la ejecución de la "pena” se materialice reproche alguno. $\mathrm{Y}$ es precisamente esta ausencia de la connotación de reproche lo que distingue a las medidas de seguridad, cuya imposición es el resultado de la adopción de una actitud puramente objetivante.

\section{II.4. Las formas de pena retributiva}

\section{a) Penas crueles e inusuales: el caso de la pena de muerte}

Lo anterior admite ser radicalizado: sólo en tanto el sentido de la imposición de la pena sea la expresión de un reproche merecido por el quebrantamiento de una norma vinculante, el sujeto penado sigue siendo reconocido como un igual agente moral. El derecho penal del ciudadano es un derecho penal retributivo, en tanto el reconocimiento del culpable como agente racional y autónomo constituye el presupuesto de la pragmática de la pena retributiva. Y la identificación de este presupuesto pragmático puede tener consecuencias importantes para la determinación de qué clases de pena pueden ser justificadas bajo el principio de retribución, esto es, cuáles son los males cuya irrogación es adecuada para la expresión del reproche merecido.

A este respecto, el debate acerca del estatus de la pena de muerte bajo la proscripción de la imposición de penas crueles e inusuales establecida en la octava enmienda a la Constitución de los EE.UU. de Norteamérica es altamente ilustrativo. Si bien el Tribunal Supremo federal jamás ha declarado que la pena de muerte sea per se una modalidad de castigo cruel e inusual $^{185}$, la pregunta que aquí interesa es si la pena de muerte puede constituir una forma de reacción punitiva retributivamente justificada. En sus tiempos de retribucionista de inspiración kantiana, Jeffrie Murphy defendió una respuesta negativa esta pregunta ${ }^{186}$. La retribución admite ser entendida como una teoría de la justicia de la pena: la pena es justa si y sólo si ella se impone en atención a su merecimiento por parte de una persona, esto es, de un sujeto racional y autónomo constituido en dignidad. De ahí

${ }^{185}$ Esto no obsta a que en la jurisprudencia del tribunal supremo se encuentre una línea de precedentes consistentes con la tesis de que la pena de muerte tiene un estatus especial bajo la octava enmienda, lo cual determina que a su respecto resulten aplicables exigencias de legitimación retrospectiva que son aplicables a ninguna otra clase de pena.

${ }^{186}$ Murphy, Jeffrie: “Cruel and Unusual Punishments”, 1979, pp. 223-249. 
que sean injustas, y por ende, estén categóricamente excluidas, aquellas formas de pena que degradan o deshumanizan al sujeto que sufre su imposición.

La identificación de esta condición se obtiene mediante una reflexión acerca de las nociones centrales sobre las cuales se articula la concepción retribucionista: las nociones de justicia y merecimiento, las cuales sólo tienen sentido bajo la presuposición de que el comportamiento respecto de cual la reacción ha de ser justa y merecida es el comportamiento imputable a un agente racional y autónomo ${ }^{187}$. Siguiendo a Kant, Murphy sostenía que hay a lo menos dos maneras de quebrantar esta exigencia de justicia retributiva: imponiendo una pena que en todo caso, cualquiera sea la naturaleza del comportamiento punible, resulta degradante; o bien imponiendo una pena que resulta desproporcionada en relación con el comportamiento punible en cuestión, esto es, excesiva ${ }^{188}$. En ambos casos, la pena es injusta desde un punto de vista retributivo, en tanto ella no es merecida, ya sea porque el autor del delito no la merece, ya sea porque ninguna persona podría merecerla.

El estatus de la pena de muerte es peculiar bajo la consideración anterior. Kant mismo, como es sabido, defendía la legitimidad de la pena de muerte impuesta a consecuencia de un asesinato. En la jurisprudencia del Tribunal Supremo federal de los EE.UU. en relación con la octava enmienda, las restricciones constitucionales a la imposición de la pena de muerte han sido fundamentadas en términos de una exigencia de proporcionalidad retrospectiva, en el sentido de que frente a delitos de determinada entidad, por ejemplo, una violación ${ }^{189}$, o frente a delitos cometidos por cierta clase de sujetos, por ejemplo, individuos que padecen cierto grado de deficiencia mental o individuos menores de 18 años ${ }^{190}$, la pena de muerte deviene cruel e inusual. Lo que es común a estas proposiciones es la idea de que la justicia de la pena de muerte debe ser evaluada en términos de la exigencia de proporcionalidad retrospectiva que son impuestas por razones de retribución, una exigencia que no sería igualmente pertinente tratándose de otras formas de pena.

La tesis de Murphy, en cambio, consiste en la proposición de que la pena de muerte, por la sola clase de hard treatment que ella constituye, no es retributivamente justificable. La primera razón por la cual una determinada clase de pena puede resultar injusta en este sentido se encuentra en que

${ }^{187}$ Ibídem, p. 233.

${ }^{188}$ Ibídem, p. 233-234.

${ }^{189}$ Coker v. Georgia, 433 US 584 (1977).

${ }^{190}$ Atkins v. Virginia, 536 US 304 (2002); Roper v. Simmons, 543 US 551 (2005). 
una reacción de determinadas características puede constituir una manera inhumana de relacionarse con otra persona. Hay determinadas clases de reacción, sostiene Murphy, aduciendo como ejemplo la electrocución de los testículos de un hombre, respecto de las cuales no cabe esperar que la persona que la sufre entienda, tome posición, o pueda participar en un discurso acerca de lo que está teniendo lugar ${ }^{191}$. Ciertamente, no puede probarse, agrega, Murphy, que tratar de esa manera a una persona sea algo incorrecto; se trata más bien de constatar que hay un paradigma de las maneras en que una persona no ha de ser tratada que constituye un presupuesto de cualquier concepción de la justicia que pueda tenerse al respecto $^{192}$.

Murphy concede, sin embargo, que en determinados casos la imposición de la pena de muerte podría ser proporcionalmente ajustada al reproche merecido por el autor del delito. Y Murphy descarta que la ejecución de la pena de muerte constituya, como sí ocurre con la tortura, un acto necesariamente deshumanizante, sugiriendo que no puede negarse la posibilidad de que aquí se satisficiera un requerimiento de muerte con dignidad (tal como éste se invoca, por ejemplo, en la discusión sobre la permisión de la eutanasia) ${ }^{193}$. ¿Por qué habría que afirmar, entonces, que la pena de muerte sea siempre retributivamente injusta?

Analizando algunos argumentos invocados en el célebre caso Furman v. Georgia ${ }^{194}$, Murphy considera la objeción procedimental tradicionalmente dirigida en contra de la pena de muerte, referida al riesgo de condena errónea de un inocente. La garantía del debido proceso de ley tendría que concretarse en estándares mucho más exigentes para la imposición de la pena de muerte que para otras clases de pena, no porque las consecuencias de aquélla sean irrevocables, dado que las consecuencias (ya actualizadas) de una pena de presidio también lo son, sino porque ellas son necesariamente incompensables ${ }^{195}$. Pero esto no agota el punto, añade Murphy, pues hay una consideración sustantiva que también parece decisiva para la conclusión de la injusticia retributiva de la pena de muerte: la ejecución de la pena de muerte conlleva la destrucción de una posibilidad que es crucial

\footnotetext{
${ }^{191}$ Murphy, Jeffrie: “Cruel and Unusual Punishments”, 1979, p. 233.

192 Ibídem, pp. 233-234.

193 Ibídem, pp. 236-237.

194408 US 238 (1972). En este caso, el tribunal negó la constitucionalidad de
} las sentencias a muerte dictadas contra los peticionarios, sin que la decisión se fundara en una opinión del tribunal, sino sólo en opiniones concurrentes de la mayoría de sus miembros, dos de los cuales, Brennan y Marshall, sostuvieron la tesis de que la pena de muerte constituía siempre una pena cruel e inusual.

${ }^{195}$ Murphy, Jeffrie: “Cruel and Unusual Punishments”, 1979, pp. 238-242. 
desde el punto de vista moral y que es constitutiva de lo que significa ser persona, a saber, la posibilidad de desarrollo de la propia identidad moral ${ }^{196}$. Parece improbable que pueda mostrarse respeto por la dignidad de otra persona si se está dispuesto a interrumpir y destruir aquellas capacidades y aquellos proyectos que son condiciones constitutivas del ser persona. A este respecto, es sumamente ilustrativa la sugerencia, hecha por el juez Brennan en su opinión recaída en Furman, de la semejanza que cabe reconocer entre la pena de muerte y la pena de expatriación, en tanto ésta aparece definida por el hecho de que entraña "la destrucción total del estatus del individuo en la sociedad organizada", en el sentido de que "el expatriado ha perdido su derecho a tener derechos"197.

Negar a otro la posibilidad de emprender o proseguir el desarrollo de la propia personalidad socava, de este modo, el presupuesto pragmático de la pena retributiva. Pues, como sugiere Nozick, lo distintivo de la concepción retributiva de la pena se encuentra en que el autor del reproche reconoce al destinatario del reproche como alguien que, a su vez, es capaz de reconocer la conexión valorativa entre el comportamiento cuya realización es objeto del reproche y la respuesta punitiva en que se expresa este reproche. En principio al menos, la imposición de la pena de muerte destruye la posibilidad de que el destinatario del reproche efectúe tal reconocimiento de esa conexión valorativa ${ }^{198}$.

\section{b) Consecuencias para la pena privativa de libertad}

La pena de muerte, por ende, no puede ser admitida como una forma de realización de la justicia retributiva, porque ella es incompatible con el fundamento moral del principio de retribución. Y como el propio Murphy observa, en esto la pena de muerte no está sola. Una pena de presidio cuya duración y condiciones de ejecución determinan que el individuo sometido a ella desarrolle una "personalidad institucional", es una pena retributivamente injusta, pues un fenómeno tal admite ser descrito como una especie

196 Ibídem, pp. 242-243. Típicamente, la articulación de teorías de la retribución que, a diferencia de la de Murphy, ponen el énfasis en la magnitud del daño causado a la víctima por el delito para la determinación de la pena merecida conlleva una defensa de la pena de muerte como reacción legítima frente a delitos de asesinato y otros delitos graves. A este respecto, es altamente instructivo el caso de Corlett, quien en esta línea defiende una ley del talión modificada (véase Corlett, J. Angelo: Responsibility and Punishment, 2004, pp. 73-93).

197408 US 289 (1972).

198 Nozick, Robert: Philosophical Explanations, 1981, pp. 374-380, 378. 
de muerte de la personalidad ${ }^{199}$. El punto, nuevamente, puede ser radicalizado: si la pena retributiva sólo se justifica en tanto ella se impone porque se satisfacen las condiciones de merecimiento de reproche, cualquier clase de reacción estatal impuesta por razones distintas no es retributivamente justa.

En este punto, es pertinente atender a la descripción ofrecida por Foucault del sentido político-tecnológico de la privación de libertad en la prisión. Pues bajo la configuración de la privación de libertad, estrictamente, como pena, o sea, bajo la exigencia de funcionalidad de la privación de libertad carcelaria a la expresión del reproche de culpabilidad, algunos de sus rasgos más salientes resultan difíciles de explicar. Desde ya, lo que Foucault denomina la "evidencia de la prisión”, esto es, el hecho de que su existencia resulte algo aparentemente no necesitado de justificación, a pesar de que no es más que una de las tantas posibilidades para la organización de la pena ${ }^{200}$. En términos de Feinberg, la pregunta tendría que apuntar al porqué de esta hegemonía del hard treatment implicado en la ejecución de la pena privativa de libertad como símbolo, esto es, dispositivo convencional, de la expresión de reproche. Que la prisión sea un dato evidente de la vida social se explica mucho mejor, siguiendo a Foucault, si su función es entendida como una modificación y/o neutralización de un individuo peligroso. Pues la prisión no es, de hecho, sólo el lugar donde se verifica esa "detención legal", sino también una "empresa de modificación de individuos". Pero sobre todo se hace manifiesto el sentido de la transformación del objeto de la privación de libertad que se opera en la prisión:

Pero esto implica que el aparato penitenciario, con todo el programa tecnológico de que se acompaña, efectúa una curiosa sustitución: realmente recibe un condenado de manos de la justicia; pero aquello sobre lo que debe aplicarse no es naturalmente la infracción, ni aun exactamente el infractor, sino un objeto un poco diferente, y definido por unas variables que al menos al principio no estaban tomadas en cuenta por la sentencia, por no ser pertinentes sino para una tecnología correctiva. Este personaje distinto, por quien el aparato penitenciario sustituye al infractor condenado, es el delincuente ${ }^{201}$.

Que en la prisión opere esa transformación es enteramente consistente con la negación del reconocimiento del individuo como un igual agen-

${ }^{199}$ Murphy, Jeffrie: “Cruel and Unusual Punishments”, 1979, pp. 239-240, 243.

${ }^{200}$ Foucault, Michel: Vigilar y Castigar, 1976, p. 234.

201 Ibídem, p. 255. 
te moral. Lo notable es que esta descripción del funcionamiento de la prisión resulta particularmente ajustada al fundamento tradicional de las medidas de seguridad y corrección, lo que tradicionalmente se entiende como una segunda vía del derecho penal.

Esta sugerencia, por lo demás, vuelve evidente el nexo funcional entre la privación de libertad tras la condena y la prisión preventiva durante el transcurso del proceso penal. Si la privación de libertad tras la condena es configurada institucionalmente como pena (retributiva), o sea, como un modo adecuado de expresar reproche a la persona, la prisión preventiva deviene difícilmente justificable. Pues, si como sugiere Walzer, la pena es un reconocimiento negativo, su imposición exige merecimiento, frente a lo cual la prisión o detención preventiva ha de considerarse un acto tiránico ${ }^{202}$. Si la privación de libertad tras la condena, en cambio, equivale funcionalmente a una medida de seguridad justificada prospectivamente, como intervención de táctica social sobre un enemigo peligroso, la prisión preventiva durante el proceso parece resultar igualmente evidente o natural. Como "medida cautelar" dispuesta durante el transcurso del proceso penal, la privación de libertad resulta de facto indicada en la medida en que haya antecedentes suficientes sobre la peligrosidad del individuo ${ }^{203}$. Desde el punto de vista de la justicia retributiva, una medida cautelar personal constituye una contradicción en los términos. Pues la imposición de una medida cautelar sobre una persona se corresponde bastante bien con lo que Kant entendería como la reducción de la persona a cosa, que en definitiva siempre es el precio de una pena preventiva.

\section{c) ¿Doble vía?}

También en cuanto a las modalidades de irrogación de mal que son admisibles como formas de pena, entonces, la adopción de una teoría retribucionista que es reflexiva acerca de los presupuestos pragmáticos del juicio de merecimiento de reproche produce exigencias que los actuales sistemas penales parecen difícilmente satisfacer. Siempre que la reacción “punitiva” se impone de modo incongruente con el reconocimiento de per-

${ }^{202}$ Walzer, Michael: Las Esferas de la Justicia, 1993, pp. 282-283.

${ }^{203}$ Ciertamente, hay otros fundamentos posibles para una privación de libertad del imputado durante el proceso penal: paradigmáticamente, el aseguramiento del desarrollo exitoso del procedimiento. Las características de una medida así justificada, empero, obviamente tendrían que ser diferentes de aquellas que son propias de una prisión preventiva que, funcionalmente, se orienta a anticipar el efecto preventivo de la "pena". 
sonalidad que la expresión de reproche supone, esa reacción deja de constituir una prestación propiamente penal. Esta consideración tendría que conducir a poner en cuestión la posición de las medidas de seguridad y corrección como forma de reacción jurídico-penal. Una definición retributiva de la función del derecho penal encierra la tesis de que en éste no hay espacio para una doble vía: las medidas de seguridad no son formas de reacción penal, sino que han de ser reconducidas a lo que se conoce como derecho de policía, que es un derecho de medidas de intervención cuya justificación es puramente preventiva.

Que una medida de seguridad pueda imponerse en el contexto institucional de un proceso penal es a este respecto tan irrelevante como lo es el hecho de que en ese mismo contexto pueda discutirse y adjudicarse una pretensión de indemnización civil. Suponer que el contexto institucional del proceso penal determina la "naturaleza penal" de las medidas de seguridad es subordinar la función del derecho penal a algunas propiedades estructurales. Pero sólo hay una función propiamente penal, que es la que desempeña la pena retributiva.

\section{II.5. Culpabilidad democrática}

a) ¿Irrelevancia de la retribución para la teoría de la legislación?

Una de las implicaciones más notables de una teoría retribucionista de la pena consiste en la exigencia de legitimidad de las normas cuyo quebrantamiento es objeto de reproche penal. La legitimidad del reproche presupone la legitimidad de las normas de comportamiento reforzadas punitivamente, pues sólo así el reproche puede considerarse merecido. Esta exigencia de justicia retributiva se encuentra consistentemente reconocida por Michael Moore, según quien la identificación de la retribución como la función del derecho penal ha de conllevar la adopción de una teoría jurídico-moralista de la legislación ${ }^{204}$.

La pena retributiva es justa en tanto ella es proporcionalmente adecuada al reproche merecido. El merecimiento es función de la combinación de las condiciones del carácter incorrecto de un comportamiento y de la responsabilidad personal por ese comportamiento. Es obvio que la incorrección del comportamiento, como primer elemento de la determinación del merecimiento, necesariamente depende de que una norma prohíba esa forma de comportamiento. Al legislador cabría oponer, entonces, una teoría jurídi-

${ }^{204}$ Moore, Michael: Placing Blame, 1997, pp. 71-78. 
co-moralista acerca de qué normas (de comportamiento) pueden ser reforzadas punitivamente (a través de normas de sanción). Una teoría jurídicomoralista de la legislación es una teoría normativa acerca de la moralidad del derecho, de conformidad con la cual el legislador debe prohibir todas y cada una de las conductas que son moralmente incorrectas, y debe hacerlo porque son moralmente incorrectas ${ }^{205}$.

Lo único que interesa, por el momento, es mostrar cómo una teoría de la pena retributiva está lejos de carecer de implicaciones para la definición de cuáles deben ser las normas de comportamiento reforzadas punitivamente. En este punto, puede ser ilustrativo considerar cómo ésta ha sido una objeción formulada en contra de las teorías retribucionistas por parte de sus opositores. Roxin, por ejemplo, mantiene que una teoría de la retribución "no explica en absoluto cuándo se tiene que penar, sino que dice tan sólo: 'Si imponéis — con los criterios que sea - una pena, con ella tenéis que retribuir un delito"”, de lo cual se seguiría que tal teoría "[n]o impide que se incluya en el Código Penal cualquier conducta y, si se dan los criterios generales de imputación, efectivamente se la castigue; en tanto en cuanto, da un cheque en blanco al legislador"206. Probablemente sea difícil encontrar una petición de principio más inequívoca en la formulación de la supuesta falta de plausibilidad de una teoría de la pena retributiva. Pues lo que Roxin supone es que el principio de retribución se reduce a requerir la satisfacción de las condiciones de imputación para fundamentar la legitimidad del reproche penal. De esta manera, parece obvio entender que ese principio sólo podría constituir un criterio limitador, no constituyente, de la necesidad de pena, que es precisamente la función (unilateral) que, en el marco de su propia teoría dialéctica de la unión, Roxin asigna al principio de culpabilidad.

Roxin reduce así la exigencia de merecimiento a la exigencia de la satisfacción de las condiciones de la responsabilidad personal por el comportamiento punible, desconociendo que el merecimiento de reproche también concierne a la definición de las características del comportamiento que lo hacen incorrecto. Las normas de comportamiento cuyo quebrantamiento legitima la imposición de la pena han de ser normas de comportamiento legítimas, y además han de ser normas de comportamiento cuyo reforzamiento punitivo resulte congruente con el propio fundamento de la pena retributiva. Como se desprende de la tesis de Moore, una teoría de la retribución conlleva un programa legislativo que, contra todo pronóstico, tendría que resultar claramente restrictivo del ejercicio de la potestad punitiva.

${ }^{205}$ Ibídem, p. 754.

${ }^{206}$ Roxin, Claus: “Sentido y Límites de la Pena Estatal”, 1976, p. 13. 
Lo anterior no significa que la defensa de una teoría jurídico-moralista de la legislación esté exenta de dificultades. El fundamento de la conexión de esta teoría con una teoría de la pena retributiva se encuentra, como ya se mostró, en que sólo en tanto las prohibiciones reforzadas punitivamente estén referidas a comportamientos moralmente incorrectos el reproche penal será merecido. Esto presupone que el derecho no puede constituir, sino que a lo más corresponderse con, la base de un reproche merecido, salvo en aquellos casos en que Moore entiende que el derecho crea prohibiciones moralmente inexistentes para resolver algún problema de coordinación ${ }^{207}$. Así, cuando una norma jurídica, punitivamente reforzada, ordena la conducción de automóviles por uno de los dos lados de la calzada, esa norma no está reproduciendo el contenido de alguna exigencia moral preexistente, sino que está definiendo como incorrecta una forma de conducta para así resolver un problema de coordinación. Esto no obsta, empero, a que Moore sostenga que en tal caso el comportamiento contrario a la norma es moralmente incorrecto, mas sólo porque ese comportamiento infringe una obligación moral que todos tenemos de resolver problemas de coordinación cuya falta de solución conlleva riesgos de daño para todos ${ }^{208}$.

El presupuesto de esta tesis se encuentra en la proposición de que los ciudadanos no tienen una obligación de obedecer el derecho sólo porque sea derecho: la normatividad del derecho sólo puede fundarse en la moralidad del derecho, lo cual se corresponde con la versión de teoría de derecho natural que Moore defiende sobre la base de su concepción del derecho como una clase funcional ${ }^{209}$. Nótese que ésta es una tesis más fuerte que aquélla según la cual la obligación de obedecer el derecho sólo puede ser una obligación moral, pues de lo contrario la norma jurídica que estableciera la obligación de fidelidad al derecho sería una norma autoreferente. La tesis de Moore es que el derecho nada agrega en cuanto a las normas que nos obligan, independientemente de que el establecimiento de una prohibición punitivamente reforzada provea razones prudenciales para el seguimiento de la norma: "el pasaje de una ley prohibiendo cierta conducta nada añade a nuestras obligaciones morales preexistentes respecto de tal conducta” ${ }^{210}$.

${ }^{207}$ Moore, Michael: Placing Blame, 1997, pp. 72-73; Moore, Michael: Act and Crime, 1993, pp. 243-244.

${ }^{208}$ Ibídem.

${ }^{209}$ Véase Moore, Michael: "Law as a Functional Kind”, 1992, pp. 188-242;

Moore, Michael: "Law as Justice”, 2004, pp. 261-291.

${ }^{210}$ Moore, Michael: Placing Blame, 1997, p. 72. 


\section{b) Neutralidad del derecho y culpabilidad democrática}

El problema que plantea esta última tesis de Moore es que ella parece difícilmente compatible con la normatividad del derecho. Pues siguiendo a Moore, ésta sería enteramente superviniente a la normatividad de la moral, de modo tal que ella tendría que ser, en definitiva, irrelevante. El punto está en que Moore concede que la cuestión podría ser distinta si se adopta una teoría política bajo la cual el derecho sí puede ser obligante con independencia de su contenido, de manera que el quebrantamiento de normas jurídicas pudiera constituir, y no sólo replicar, el objeto de un reproche legíti$\mathrm{mo}^{211}$.

Ésta es precisamente la tesis subyacente a lo que en la teoría penal alemana contemporánea se conoce como la fundamentación discursiva del reproche de culpabilidad. La premisa se encuentra en que el reproche penal de culpabilidad no puede ser reducido a un reproche moral. El reproche penal de culpabilidad es un reproche jurídico, de modo tal que el mismo ha de poder ser fundamentado como el reproche merecido por el quebrantamiento de una norma jurídica. La diferenciación del reproche jurídico-penal de culpabilidad respecto de un reproche puramente moral exige que en la identificación del fundamento legitimante del reproche sea respetado lo que Kindhäuser denomina el mandato de neutralidad del derecho, que es el mandato según el cual el derecho debe ser neutral en cuanto a los motivos que el ciudadano puede tener para no quebrantar las normas jurídicas ${ }^{212}$. El problema consiste en resolver el dilema que parece seguirse de la necesidad de conjugar la pretensión de legitimidad que las normas jurídicas han de tener para que su quebrantamiento pueda justificar un reproche con este mandato de neutralidad que impide que el derecho se disuelva en moral. Pues la pretensión de corrección inmanente al derecho determina que la pretensión de fidelidad al derecho deba descansar en la consideración de que las normas deben poder ser aceptadas como legítimas por sus destinatarios, aun cuando de hecho éstos no las acepten ${ }^{213}$.

El punto de partida para la solución es sugerido por el propio Kindhäuser, cuando mantiene que

no hay, en una sociedad secularizada y pluralista, fundamentos sustanciales a priori para legitimar las normas que regulan

${ }^{211}$ Ibídem, p. 662.

212 Kindhäuser, Urs: "La Fidelidad al Derecho como Categoría de la Culpabilidad", 2000, pp. 172-174.

${ }^{213}$ Duff, R.A.: "Law, Language and Community: Some Preconditions of Criminal Liability”, 1998, p. 199. 
el comportamiento. De ahí que la legitimidad solamente pueda ser deducida de la autonomía de los partícipes en el proceso de integración social ${ }^{214}$.

La pretensión de legitimidad de las normas jurídicas de comportamiento, de conformidad con la cual cabe fundamentar una expectativa de fidelidad al derecho, no puede depender de su contenido, sino sólo de la identificación de una razón por la cual, independientemente de su contenido, la norma pueda ser entendida como una norma del sujeto a quien se reprocha su quebrantamiento. Esta vinculación entre norma y sujeto sólo puede obtenerse de una atribución de autonomía comunicativa, que designa el entrecruzamiento de una dimensión de autonomía pública (la "libertad de los antiguos”) y una dimensión de autonomía privada (la "libertad de los modernos”), en virtud de la cual el sujeto se constituye en autor, pero también en destinatario de la norma. Es en una esfera de autonomía pública que el sujeto se constituye en (co-)autor de la norma a cuyo seguimiento el mismo sujeto se encuentra obligado en una esfera de autonomía privada. Autonomía pública y autonomía privada se entrecruzan en la constitución de la autonomía o libertad comunicativa, que condiciona la vinculación del sujeto a la norma como su destinatario, en tanto la norma puede ser reconducida al propio sujeto como interviniente (potencial) en el proceso de su establecimiento $^{215}$.

La atribución de libertad comunicativa se corresponde con la configuración de lo que Klaus Günther denomina persona deliberativa ${ }^{216}$. Es persona deliberativa aquella a la cual se reconoce libertad comunicativa, que puede entenderse como la capacidad de tomar posicionamiento crítico, tanto frente a manifestaciones y acciones ajenas como frente a manifestaciones y acciones propias. El carácter crítico de la toma de posición se sigue de que ella sea apoyada en razones. Según Günther, las razones se definen por el hecho de que ellas "hacen una diferencia en el mundo, en tanto pueden motivar a una persona a la revisión y modificación de sus manifestaciones y acciones”217. En su componente de autonomía pública, la libertad comunicativa de la persona deliberativa la posiciona como ciudadano del Estado, de modo que la capacidad de participar en el procedimiento democrático de establecimiento de normas, tomando posición crítica frente

${ }^{214}$ Kindhäuser, Urs: "La Fidelidad al Derecho como Categoría de la Culpabilidad”, 2000, pp. 194-195.

${ }^{215}$ Ibídem, p. 196.

${ }^{216}$ Günther, Klaus: Schuld und kommunikative Freiheit, 2005, pp. 245-246.

${ }^{217}$ Ibídem. 
a los actos de justificación de normas, hace posible reconducir éstas a la autonomía del ciudadano. Esta reconducción de la norma a la autonomía de la persona deliberativa en tanto ciudadano es lo único que justifica la pretensión de vinculación a la norma que puede dirigirse contra la persona deliberativa que, en una dimensión de autonomía privada, se posiciona como persona de derecho (Rechtsperson), y en esta medida, como destinatario de la norma ${ }^{218}$.

Es fundamental advertir la relación precisa entre la atribución de la condición de persona deliberativa y la obligación de seguir la norma que legitima el reproche por la ejecución de un comportamiento que expresa una falta de reconocimiento de la norma. En especial, ha de enfatizarse la diferencia entre discurso y procedimiento democrático, pues sólo de ese modo puede darse cuenta de la posibilidad mediadora entre facticidad y validez que cabe atribuir al derecho. El procedimiento democrático está organizado de modo tal que posibilita, en cierto espacio de tiempo, decisiones mayoritarias sobre la validez positiva de normas jurídicas. Esto implica que las normas jurídicas, democráticamente establecidas, también rigen respecto de un sujeto que de facto no hace uso de su capacidad de autonomía pública para tomar parte, críticamente, en discursos públicos ${ }^{219}$. Antes bien,

El deber de cada ciudadano del Estado al seguimiento de la norma se fundamenta sólo en su igual derecho al ejercicio público de su capacidad crítica y en el procedimiento jurídicamente institucionalizado en el cual este derecho puede ser ejercido $-\mathrm{y}$ no, en cambio, en el si y cómo ni en el resultado del ejercicio de este derecho ${ }^{220}$.

Por esto, el destinatario de la norma puede decidir si y por qué razón ha de seguir la norma. Un seguimiento de la norma puramente estratégico, esto es, un seguimiento puramente prudencial de la norma, no justifica reproche alguno. Dentro del acuerdo expresado en las normas jurídicas vigentes, a la persona de derecho cabe reconocer un espacio de libertad instrumental, que es lo que hace posible que tengamos vidas privadas. Así se cumple con el mandato de neutralidad que el derecho no puede desconocer en su pretensión de vincular al destinatario de la norma ${ }^{221}$.

${ }^{218}$ Ibídem, pp. 249-250; Habermas, Jürgen: Facticidad y Validez, 1998, pp. 186-187.

${ }^{219}$ Günther, Klaus: Schuld und kommunikative Freiheit, 2005, p. 250.

${ }^{220}$ Ibídem, p. 251.

${ }^{221}$ Kindhäuser, Urs: "La Fidelidad al Derecho como Categoría de la Culpabilidad”, 2000, pp. 198, 202, 205. 


\section{c) La doble función del principio de legalidad}

La exigencia de fijación legal de la sanción penal, esto es, el anuncio de la imposición de la pena contenida en las normas de sanción de la ley penal, resulta enteramente congruente con el mandato de neutralidad: el Estado reconoce la posibilidad de que el destinatario de la norma de comportamiento no la siga como consecuencia de un ejercicio de capacidad de crítica conducente al asentimiento, sino que la siga exclusivamente motivado por la ventaja de evitar la sanción ${ }^{222}$. Esto hace posible, de paso, poner en cuestión la observación de von Hirsch en cuanto a que, al proveer una razón prudencial que refuerza la razón normativa que la norma de comportamiento entraña, la conminación legal de la sanción (o sea, el anuncio legal previo del hard treatment) ha de concebirse como un mecanismo preventivo de desincentivo del incumplimiento de la norma ${ }^{223}$. Frente a esto, sin embargo, el establecimiento legal previo de la sanción punitiva (nullum crimen, nulla poena sine lege praevia) admite ser concebido como una exigencia derivada del mandato de neutralidad, cuyo sentido es hacer posible un seguimiento prudencial de la norma, de modo tal que, a pesar de evidenciar una pretensión de legitimidad, el derecho no imponga al ciudadano la aceptación crítica de la norma como el motivo para su seguimiento.

Pero el reproche penal de culpabilidad sólo se justifica, por contrapartida, cuando el comportamiento de la persona de derecho pone de manifiesto una falta de reconocimiento de la norma como una razón eficaz para la acción, en la medida que ella misma pudo participar, como ciudadano, en el procedimiento de adopción de la norma. Por eso, la exigencia de legalidad de la norma de comportamiento cumple la función inversa a la de la exigencia de legalidad de la norma de sanción: mientras que el establecimiento legal de la norma de sanción es reconocimiento de libertad instrumental, la legalidad de la norma de comportamiento es el sello institucional de que esa norma es resultado del procedimiento democrático, de modo que la norma puede ser atribuida al ejercicio de la libertad comunicativa del ciudadano en su faz de autonomía pública. Por eso, en el nivel de la norma de comporta-

${ }^{222}$ Günther, Klaus: Schuld und kommunikative Freiheit, 2005, p. 252; Habermas, Jürgen: Facticidad y Validez, 1998, pp. 177-178. El mandato de neutralidad impide fundamentar la culpabilidad material como autocontradicción del autor como sujeto racional al modo kantiano, pero también como autocontradicción del sujeto como ciudadano en el sentido tradicional del comunitarismo (véase Kindhäuser, Urs: “La Fidelidad al Derecho como Categoría de la Culpabilidad”, 2000, pp. 172-185).

${ }^{223}$ Hirsch, Andrew von: Past or Future Crimes, 1985, pp. 12-13. 
miento el principio de legalidad no puede ser entendido como un criterio de limitación, sino como una condición constitutiva del carácter vinculante de la norma 224 .

\section{d) Nuevamente: culpabilidad como falta de reciprocidad}

Lo anterior no equivale a disolver la distinción entre autonomía privada y autonomía pública. Como ciudadano, la persona deliberativa tiene derecho a rechazar la norma y a tomar parte críticamente en el proceso político, abogando por su supresión o modificación. Pero la persona deliberativa no puede invocar este derecho cuando, en su rol de persona de derecho, se encuentra en una situación en que está obligada a seguir la norma $^{225}$. Si abandona el ámbito de libertad instrumental acordado y que se expresa en las normas de comportamiento vigentes, la persona deliberativa queda sujeta a una obligación de lealtad comunicativa: el rechazo del acuerdo debe justificarse en el marco del procedimiento institucional disponible para su revisión ${ }^{226}$. Como afirma Günther, “el Estado democrático de derecho vive del cambio regulado e institucionalizado entre los roles de ciudadano y persona de derecho"227. La lealtad comunicativa, como correlato de la libertad comunicativa atribuida a la persona deliberativa, consiste en no arrogarse unilateralmente ese cambio de roles.

Esta obligación de lealtad comunicativa designa la expectativa de reciprocidad que los ciudadanos mantienen entre sí. Las normas de comportamiento jurídicamente vigentes definen aquellos ámbitos de actuación en que los ciudadanos pueden dejar de tener que entenderse unos con otros acerca de su comportamiento: un derecho negativo de libertad, correlativo

${ }^{224}$ A este respecto, es completamente irrelevante que la norma de comportamiento y la norma de sanción se encuentren formuladas en una misma disposición legal. En la legislación penal ordinariamente se encuentran disposiciones que en su estructura explícita sólo reproducen normas de sanción (“el que mate a otro será sancionado con la pena de...”). La norma que prohíbe el comportamiento que constituye el supuesto de hecho de la aplicación de la sanción, es inferida pragmáticamente. En todo caso, lo que importa es advertir que el sentido de la exigencia de legalidad es diferente en uno y otro plano de análisis, independientemente de que esa legalidad doble sea obtenida mediante la fijación de una sola disposición legal. Una aplicación diferente de la tesis de que el principio de legalidad se justifica de modo diferente en relación con la norma de comportamiento (rules of conduct) y en relación con la norma de sanción y las reglas de imputación (principles of adjudication) se encuentra en Robinson, Paul: "Fair Notice and Fair Adjudication: Two Kinds of Legality”, 2005, pp. 154 ss.

225 Günther, Klaus: Schuld und kommunikative Freiheit, 2005, p. 252.

${ }^{226}$ Kindhäuser, Urs: "La Fidelidad al Derecho como Categoría de la Culpabilidad”, 2000, pp. 198-199.

${ }^{227}$ Günther, Klaus: Schuld und kommunikative Freiheit, 2005, p. 253. 
al deber que la norma impone sobre terceros, "es también un derecho a la irracionalidad", que introduce un componente "disociativo" en la integración social cooperativa ${ }^{228}$. Para que los demás puedan disponer de este ámbito de libertad instrumental, han de poder confiar que el sujeto de derecho no va a sobrepasar ese espacio, quebrantando la norma. La obligación de lealtad comunicativa, por ende, no es más que una expectativa de reciprocidad en el reconocimiento de iguales espacios de libertad instrumental. Y ésta es la concepción democrática de la expectativa de fidelidad al derecho, cuya manifestación positiva no es exigida, sino sólo desaprobada su ausencia, la cual se expresa en el quebrantamiento de la norma, que es el objeto del reproche penal ${ }^{229}$.

La imposición de la pena, de este modo, es la forma institucionalizada de expresión de reproche merecido por el quebrantamiento de una norma que evidencia una falta de sentido de la justicia a través de la defraudación de una expectativa de reciprocidad que los miembros de una comunidad política democráticamente organizada pueden mantener unos frente a otros. La legitimidad del reproche depende, en todo caso, de la legitimidad de la norma quebrantada, cuya única garantía se encuentra en el principio de definición política que, disolviendo la contraposición entre soberano y súbdito, hace posible que seamos los autores de las normas que al mismo tiempo nos obligan. Por esto, el fundamento del reproche penal, y en definitiva, de la pena retributiva, es la política democrática. No hay garantía inmanente para este fundamento legitimante ni tampoco, por lo mismo, para la legitimidad de la pena retributiva. La legitimidad del ordenamiento jurídico descansa en la efectividad del proceso democrático, y no a la inversa. No parece posible exagerar la importancia de este punto: como lo advierte Klaus Günther, en el marco de un ordenamiento jurídico ilegítimo nadie puede ser declarado culpable ${ }^{230}$.

\section{II.6. Legislación y jurisdicción penal}

\section{a) Democracia y adjudicación}

Esta concepción del reproche penal democrático vuelve manifiesta la justificación del requerimiento de legalidad de las normas penalmente reforzadas. En tanto la ley es la expresión de las definiciones políticas de la

${ }^{228}$ Kindhäuser, Urs: "La Fidelidad al Derecho como Categoría de la Culpabilidad”, 2000, pp. 197-198.

${ }^{229}$ Ibídem, p. 205.

${ }^{230}$ Günther, Klaus: Schuld und kommunikative Freiheit, 2005, p. 4. 
comunidad democrática, la legalidad de la norma es el sello de su legitimidad. La producción democrática de la norma, expresada en su establecimiento legal, le confiere universalidad, en el sentido de que es una norma de todos y cada uno de los que forman parte de esa comunidad política. La universalidad de la norma se sigue del hecho de que esa norma es el resultado (en todo caso revisable) de un procedimiento institucional que hace posible la participación de todos en discursos de fundamentación, esto es, discursos dirigidos al ofrecimiento y la impugnación de razones a favor o en contra de la norma.

En todo sistema democrático, el proceso legislativo está organizado de modo tal de posibilitar, en la mayor medida posible, decisiones autoritativas sobre la creación de normas que descansan en razones universalizables, razones que todo sujeto tendría que reconocer como válidas. Por eso, en una democracia, el procedimiento legislativo tiene lugar, en lo fundamental, al interior de una institución representativa, pues sólo en la medida en que hay igual representación de todos en las instancias de definición de las normas vinculantes puede esperarse que en esta definición hayan sido adecuadamente considerados los intereses de cada uno de sus posibles destinatarios ${ }^{231}$. Ciertamente, esto supone que en ese sistema se satisfacen algunos criterios de democracia procedimental ${ }^{232}$.

La democracia procedimental provee, entonces, un mecanismo para la adopción de normas válidas que vinculan a todos aquellos que pueden tomar parte en ese procedimiento público. Pero la validez de la norma no implica que la aplicación de esa norma sea en todo caso adecuada. La justificación de la norma no garantiza per se la adecuación de su aplicación a cada caso particular, porque las razones que apoyan su validez (general) no necesariamente son las razones que gobiernan todos y cada uno de los casos particulares en los cuales la norma en principio resulta aplicable. Toda norma válida conlleva, entonces, una cláusula ceteris paribus, pues la legislación no está referida a caso particular alguno. En otros términos: la justificación (universal) de una norma sólo determina su validez, pero no su adecuación a cada caso particular. Si en cada caso particular la norma ha de poder ser vista como norma de los sujetos involucrados, ha de establecerse una garantía de su adecuación, o sea, una garantía de atención a lo particular de cada caso. Esta garantía tiene que hacer posible que la particularidad del caso sea observada, y para ello es indispensable una institución que

\footnotetext{
${ }^{231}$ Dahl, Robert: On Democracy, 1998, pp. 76-78.

232 Véase Dahl, Robert: “Procedural Democracy”, 1986, pp. 191-225.
} 
constituya el marco para el desenvolvimiento de discursos de aplicación ${ }^{233}$. Esta institución se denomina jurisdicción ${ }^{234}$.

Lo que la jurisdicción hace posible es la distinción entre legislación y adjudicación. En un sistema democrático, la legislación establece (extrínsecamente) lo que es razonable, de modo tal que la judicatura no puede modificar esa definición. Lo que la judicatura hace al adjudicar no es determinar qué es razonable, sino sólo qué es razonable aplicar. El principio que ha de guiar la acción judicial es aquel que ordena al adjudicador aplicar sólo lo que es razonable aplicar ${ }^{235}$. Sólo así puede asegurarse que la aplicación de una norma (en todo caso) válida a un caso particular no pase por alto la particularidad del caso; o sea, sólo así puede llenarse el vacío de particularidad que separa a todo caso de la norma universal a ser aplicada ${ }^{236}$.

\section{b) Adjudicación y ciudadanía}

Detmold muestra la conexión decisiva que se da entre este aseguramiento de la consideración de la particularidad del caso a través de la adjudicación y la pregunta por la obligación de obedecer el derecho. Para que el ciudadano pueda estar obligado a seguir una norma jurídica, esa norma ha de poder ser vista como suya en particular. Sólo un ciudadano es llevado ante un tribunal para responder por el quebrantamiento de una norma, y un ciudadano es precisamente aquel de quien puede decirse que la norma quebrantada es su norma ${ }^{237}$. En la terminología propuesta por Duff, la pertenencia a la comunidad política es, de esta manera, una precondición de la responsabilidad penal, dado que ésta presupone que el sujeto pueda ser llamado a responder frente a un tribunal que adjudica en representación del cuerpo de los ciudadanos ${ }^{238}$.

${ }^{233}$ Fundamental a este respecto Günther, Klaus: Der Sinn für Angemessenheit, 1989.

${ }^{234}$ Atria, Fernando: “Jurisdicción e Independencia Judicial: el Poder Judicial como Poder Nulo”, 2004, pp. 128-132.

235 Detmold, Michael: "Law as Practical Reason”, 1989, p. 453. El mandato de aplicar sólo lo que es razonable aplicar difiere de un mandato de aplicar lo que es razonable, pues puede ser razonable aplicar una norma que no es razonable. La razonabilidad de una norma no es lo mismo que la razonabilidad de la aplicación de esa norma. Ésta es una cuestión crucial para el diseño de los sistemas de control judicial de constitucionalidad de la ley, en tanto se trate, efectivamente, de control judicial, esto de, adjudicación. Velar por la adecuación constitucional de la aplicación de la ley no equivale a velar por la constitucionalidad de la ley.

${ }^{236}$ Ibídem, pp. 455-463.

${ }^{237}$ Ibídem, p. 461.

${ }^{238}$ Duff, R.A.: "Law, Language and Community: Some Preconditions of Criminal Liability”, 1998, p. 196. 
Esto significa que por el hecho de que un sujeto quebrante una norma ésta no deja de ser su norma; y como Detmold lo marca, esto supone que ese sujeto sea un miembro de la comunidad política bajo cuyas normas se pronuncia la condena. La determinación de la ciudadanía, por ende, es siempre una cuestión que sólo se resuelve definitivamente en el momento de la aplicación de la norma al caso particular ${ }^{239}$. La consecuencia que esto tiene para el reproche penal de culpabilidad es ineludible: sólo aquellos que pertenecen a la comunidad política pueden ser punidos, pues sólo ellos al quebrantar la norma quebrantan una norma que es suya ${ }^{240}$. El principio de judicialidad de la imposición de la pena aparece, de esta manera, como una exigencia propiamente retributiva, y no extrínseca a la justicia retributiva.

Lo anterior no es más que una formulación diferente de la tesis de que el reproche penal siempre conlleva un reconocimiento del sujeto cuyo comportamiento es objeto del reproche como miembro de la comunidad cuyo horizonte normativo constituye el contexto para la formulación del reproche. Esto es importante para clarificar el problema que puede presentarse cuando el reproche penal tiene lugar respecto de extranjeros. En tanto la culpabilidad presuponga, estrictamente, la posibilidad de tomar parte en los discursos políticos en cuyo marco se definen las normas que imponen las exigencias de conducta, cabría poner en cuestión la legitimidad de un reproche penal dirigido a un extranjero. Pero esta dificultad puede ser disuelta, en tanto se atiende a la conexión que existe entre legislación y adjudicación. Es ciertamente posible que haya sujetos que formen parte de una comunidad política sin contar (actualmente) con la posibilidad de contribuir a la formación de la voluntad colectiva participando en el proceso democrático $^{241}$. Éste es el caso regularmente tratándose de extranjeros cuya residencia en el territorio del Estado no se ha consolidado definitivamente. Que estos sujetos puedan ser llevados a responder por un quebrantamiento de una norma frente a un tribunal y resultar finalmente condenados sólo muestra que a su respecto ha habido un depósito previo de confianza que ha sido defraudado por el quebrantamiento de la norma. Parece sensato esperar una cierta medida de fidelidad al derecho, o sea, de lealtad o reciprocidad comunicativa, de un individuo que pretende formar parte de una comunidad política $^{242}$. Puesto que el reproche penal de culpabilidad es tal en tanto el mismo no es instrumentalizado, esto es, en tanto es sincero, lo que el repro-

\footnotetext{
${ }^{239}$ Detmold, Michael: “Law as Practical Reason”, 1989, pp. 462-463.

${ }^{240}$ Ibídem, p. 469.

241 Véase Dahl, Robert: “Procedural Democracy”, 1986, pp. 213-221.

242 Véase Walzer, Michael: Obligations: Essays on Disobedience, War, and
} Citizenship, 1970, p. 28. 
che penal a un extranjero muestra es que éste ya puede haber dejado de serlo $^{243}$.

Pero lo anterior debe ser tomado con cuidado, dado que no es posible descartar sin más que un no-ciudadano sea de hecho llevado a responder frente a un tribunal. Y, como mantiene Duff, en la medida en que éste sea el caso, aun cuando el tribunal se sujete a las reglas que normalmente constituyen a un proceso penal como tal, este proceso no será un auténtico proceso penal, por faltar una de las precondiciones de la posibilidad de que el sujeto responda, sino una parodia ${ }^{244}$.

\section{II.7. La retribución como la teoría del derecho penal}

a) Principios del ejercicio de la potestad punitiva

Puede ser oportuno efectuar un resumen de las implicaciones que la formulación de una teoría democrática de la pena retributiva ha de tener para la configuración del derecho penal como categoría funcional. Una fundamentación retributiva de la práctica punitiva exige, en primer lugar, que las normas cuyo quebrantamiento pueda ser objeto de reproche penal sean normas legítimas, normas que, en tanto aceptables para todos, puedan ser vistas como normas de cada ciudadano. En un Estado democrático de derecho, el procedimiento institucional para la formulación de las normas comunes es el procedimiento de formación de la ley, que representa la formalización del proyecto político del autogobierno. La legalidad de la norma de comportamiento es una condición constitutiva, no meramente limitativa, de la práctica de la retribución democrática.

Para la satisfacción del mandato de neutralidad que posibilita la demarcación entre derecho y moral, por otra parte, es indispensable que el derecho no prejuzgue el motivo por el cual el ciudadano efectivamente ha de cumplir con la exigencia de conducta impuesta por la norma. La legalidad de la norma de sanción, que confiere un motivo puramente prudencial para el seguimiento de la norma de comportamiento, por ende, es una condición necesaria para que el reproche penal pueda ser un reproche jurídico-penal.

${ }^{243}$ Que ya no lo sea completamente, depende de los estándares con arreglo a los cuales se evalúe la ruptura de la confianza reconocida: que respecto de un extranjero resulte más plausible el reconocimiento de un error de prohibición inevitable, excluyente de la culpabilidad, sugiere que la contraposición entre ciudadano y extranjero no es binaria, sino gradual.

244 Duff, R.A.: "Law, Language and Community: Some Preconditions of Criminal Liability”, 1998, p. 194. 
Se trata en todo caso de un reproche, y no de una acción estatal estratégica, porque el objeto del reproche es una falta de reconocimiento de una norma legítima, esto es, de una norma que un ciudadano leal al ordenamiento jurídico legítimo habría tenido que reconocer como vinculante para sí, independientemente de los motivos que de hecho el ciudadano haya podido tener para su seguimiento. Para que la norma de comportamiento pueda constituir una razón eficaz para la acción, ella debe contar como una razón vigente al momento de la realización del comportamiento, lo cual se materializa en el principio de irretroactividad de la ley penal.

La legitimidad de la norma de comportamiento, que fundamenta el reproche de culpabilidad, depende no sólo de que la norma sea (universalmente) válida, sino también de que sea adecuada en su aplicación al caso particular. Sólo de este modo el reproche de culpabilidad es el reproche dirigido a un sujeto, y no a un individuo objetivado por razones extrínsecas a sí mismo. La adecuación de la aplicación de la norma frente a la particularidad del caso es asegurada a través de la configuración de la formulación del reproche como un acto de adjudicación, de dar al ciudadano lo que éste merece, por lo cual el principio de imposición judicial de la pena aparece como una exigencia propiamente retributiva.

La consideración de la imposición de la pena como la formulación de un reproche merecido presupone, ante todo, que la pena impuesta sea un modo adecuado para la expresión de reproche, de modo tal que ella ha de ser congruente con la base pragmática del reproche, que es el reconocimiento del sujeto cuyo comportamiento se reprocha como un alter ego moral, esto es, como una persona: el principio de la humanidad de la pena es, por esto, la formulación de una condición del reproche penal. Puesto que en todo caso se trata de la formulación de un reproche merecido, la imposición de la pena retributiva sólo puede tener lugar respecto del sujeto cuyo comportamiento es constitutivo de un quebrantamiento de la norma: tanto el principio de culpabilidad como el principio de la personalidad de la pena están en el centro de la práctica retributiva. Para que la imposición de la pena exprese adecuadamente el reproche merecido, la medida de la pena debe ajustarse a la medida del merecimiento, de lo cual se sigue la exigencia de proporcionalidad de la pena.

Puesto que la formulación del reproche conlleva una condición de sinceridad, que impide que el reproche sea instrumentalizado y así disuelto en acción estratégica, la base normativa del reproche debe estar vigente en el momento del reproche y durante la materialización de su expresión a través de la ejecución de la pena: el principio de favorabilidad, esto es, el mandato de aplicación retroactiva de la ley penal favorable, también consti- 
tuye una exigencia interna a la justificación retribucionista de la pena estatal. Por último, que el derecho penal es derecho público resulta suficientemente asegurado por el hecho de que las normas cuyo quebrantamiento constituye el objeto de la expresión de reproche son normas públicas, es decir, normas de todos.

\section{b) Las condiciones constitutivas del reproche penal}

Que el desarrollo de las implicaciones de una práctica punitiva fundada en la retribución se corresponda de forma tan ajustada con este conjunto de principios cuya enunciación suele ocupar las primeras páginas de cualquier manual de derecho penal, está lejos de ser una casualidad. Que nuestra imagen de lo que debe ser el derecho penal sea tan precisamente reflejada en su descripción retribucionista sugiere que hay buenas razones para mantener que el derecho penal, en efecto, es una clase funcional, y que su función particular es la justicia retributiva. En la terminología de Ronald Dworkin, esto significa que el concepto de derecho penal (como el concepto de derecho en general) es interpretativo, en el sentido de que la descripción de lo que el derecho penal es no puede ser independiente de nuestras creencias acerca de lo que el derecho penal debe $\operatorname{ser}^{245}$.

Es difícil exagerar la importancia de este último punto. Bajo el aparato conceptual de una teoría retributivo-democrática del derecho penal, los principios de legalidad, culpabilidad, personalidad y humanidad de las penas no son criterios contrapuestos que contribuyen (sólo) a restringir el ejercicio de esa potestad tan terrible que se denomina ius puniendi, esto es, no son principios limitadores del ius puniendi. Por el contrario, se trata de principios que designan condiciones constitutivas de una práctica que está definida por la función de expresar reproche merecido por el quebrantamiento de normas comunes a todos. Que el ejercicio del ius puniendi aparezca como el ejercicio de una potestad terrible sólo se debe a una inversión de la subordinación de ciertas características estructurales (la irrogación de males sensibles atroces) a la función a cuyo desempeño la estructura ha de contribuir (la expresión de reproche merecido). Partir describiendo la ejecución de un individuo en la silla eléctrica como la ejecución de una pena es partir concediendo esa inversión, esto es, partir aceptando una subordinación de la función a la estructura, que es precisamente lo contrario a una concepción funcional del derecho penal. Bajo una concepción retribucionista de la

${ }^{245}$ Dworkin, Ronald: Law’s Empire, 1986, pp. 45-86. Véase también Tunick, Mark: Punishment. Theory and Practice, 1992, pp. 165-187. 
función del derecho penal, hay mucho de lo que actualmente designamos como "derecho penal" que no es, ni puede ser, derecho penal.

Lo anterior puede ser reformulado como sigue: que usemos la etiqueta "derecho penal" para designar un complejo de acciones estatales no es condición suficiente para que exista el derecho penal como clase funcional $^{246}$. Mas si lo que cuenta como derecho penal lo hace con independencia de la función cuyo desempeño puede atribuírsele, entones el derecho penal se ha convertido o bien en una clase cuasi-natural, definida por el uso de ciertos males sensibles, como por ejemplo la silla eléctrica y el presidio perpetuo, o bien en una clase puramente nominal, una clase exclusivamente definida por el uso de esa expresión lingüística, cuyo contenido, por ende, pasa a ser arbitrario. Es exactamente este problema el que subyace a la discusión actual acerca del denominado derecho penal del enemigo, cuya descripción puede obtenerse fácilmente si se invierte cada uno de los rasgos estructurales distintivos de un derecho penal retributivo: tratamiento objetivante de individuos no reconocidos como miembros de la comunidad (“terroristas", "narcotraficantes", "pedófilos” y, en general, “delincuentes”) a través de reacciones orientadas a la prevención especial de neutralización que no resisten la distinción entre penas y medidas de seguridad ${ }^{247}$. Que el derecho penal del enemigo constituya o no un genuino derecho penal depende de si el derecho penal ha dejado de ser una clase funcional para convertirse en una clase puramente nominal. Pues si éste es el caso, cualquier cosa puede ser derecho penal ${ }^{248}$.

Con algunos matices, una observación similar podría formularse respecto de parte de lo que hoy día se entiende como derecho penal internacional. El reproche penal de culpabilidad institucionalizado en la imposición de la pena retributiva presupone que entre el autor del reproche y su destinatario hay normas comunes, esto es, que entre ellos hay comunidad. Fuera de una comunidad de sujetos vinculados no hay posibilidad de reproche alguno. En caso alguno esto significa que no haya espacio posible para un derecho penal de vigencia internacional. Sin duda que la posibilidad de un reproche punitivo en relación con hechos constitutivos de crímenes de guerra, por ejemplo, se encuentra bien fundamentada, precisamente porque en

${ }^{246}$ Y lo mismo puede decirse respecto del derecho en general. Al respecto Fuller, Lon: The Morality of Law, 1964, pp. 95-151.

${ }^{247}$ Véase Cancio Meliá, Manuel: “¿‘Derecho Penal del Enemigo’?”, 2003, pp. 57-102; Gracia Martín, Luis: “Consideraciones Críticas sobre el Actualmente Denominado Derecho Penal del Enemigo”, 2005.

248 Müssig, Bernd: "Derecho Penal del Enemigo: Concepto y Fatídico Presagio”, 2006, pp. 385-390. También Bung, Jochen: "Feindstrafrecht als Theorie der Normgeltung und der Person”, 2006, pp. 67-70. 
relación con quienes intervienen en un contexto de combate armado es posible reconocer un horizonte normativo compartido: entre dos militares combatientes que se enfrentan en el curso de una batalla no rige (al menos en los términos ordinarios) la prohibición general de matar a otro, mas sí rigen determinadas normas (establecidas, entre otros, en los Convenios de Ginebra) que determinan, por ejemplo, qué clase de armamento puede ser utilizado. Pero esto no asegura que la posibilidad de un reproche penal esté bien fundamentada en cualquier contexto ${ }^{249}$.

Lo que subyace a la discusión acerca de la precariedad de la legalidad en el derecho penal internacional es la constatación de la dificultad de fundamentar, en ese horizonte, un reproche por el quebrantamiento de normas comunes ${ }^{250}$. Y pretender encontrar normas comunes que pervivan a la superación política de un régimen ilegítimo puede constituir una ficción lamentable, porque así sólo se normaliza la violencia del régimen "superado”, al ser ella reducida a mero delito ${ }^{251}$. Como Jakobs lo pone:

puede que haya buenas razones para obligar a otro a un estado de juridicidad, pero antes de que eso haya sucedido, falta el estado de juridicidad. Derecho penal previo a un monopolio de la fuerza en funcionamiento es un mero nombre, no un concepto ${ }^{252}$.

Un derecho penal retributivo presupone algunas condiciones políticas, que son aquellas que configuran la posibilidad de un orden normativo al interior del cual sujetos vinculados se reconozcan como personas, de manera tal que esos sujetos puedan esperar cierta medida de lealtad recípro-

${ }^{249}$ Véase Jakobs, Günther: Sobre la Teoría de la Pena, 1998, p. 31. Véase también, Jakobs, Günther: “¿Superación del Pasado Mediante el Derecho Penal?”, 1994, pp. 156-158 (1994); Jakobs, Günther: "Crímenes del Estado-Ilegalidad en el Estado", 1995.

250 Sobre esto, Benhabib, Seyla: "On the Philosophical Foundation of Cosmopolitan Norms", 2007, passim.

251 Véase Atria, Fernando: "La Hora del Derecho: Los 'Derechos Humanos' entre la Política y el Derecho”, 2003, pp. 74-75. Para un desarrollo de la concepción del acto de juzgar como dependiente de un sentido de comunidad y sus implicancias para el problema de la universalidad de los derechos humanos, véase Nedelsky, Jennifer: “Communities of Judgment and Human Rights”, 2000, passim.

252 Jakobs, Günther: "La Autocomprensión de la Ciencia del Derecho Penal ante los Desafíos del Presente (comentario)”, 2004, p. 63. Para una reformulación de la distinción amigo/enemigo como distinción política fundamental en el marco de una filosofía política de democracia radical, Mouffe, Chantal: El Retorno de lo Político, 1999, pp. 11-25, 168-170, para quien el desafío que ha de asumir la política democrática es maximizar la posibilidad de constituir al enemigo en adversario, esto es, transformar el antagonismo, que es fundacional de lo político, en agonismo. 
ca, cuya defraudación justifica, o sea, amerita un reproche. Que esto es así puede mostrarse con una analogía referida al derecho de contratos. El derecho de contratos fundado en el principio de la autonomía de la voluntad sólo es posible en un contexto social en que los contratantes aparecen como agentes que se encuentran en un pie de igualdad, de modo que la satisfacción de ciertas condiciones que aseguran la concurrencia de la voluntad libre de cada contratante produce, necesariamente, un intercambio justo en términos de justicia conmutativa. Que un contexto tal no se encuentra asegurado sub specie aeternitatis, lo muestra suficientemente el surgimiento de una regulación contractual diferenciada, por ejemplo, para las relaciones laborales, definidas precisamente por la asimetría estructural entre las partes contratantes, y más concluyentemente el surgimiento de un derecho del consumidor, que descansa en la consolidación de una forma jurídica, el contrato de adhesión, muchas de cuyas cláusulas pueden estar incluso fijadas por ley, como el paradigma de "contrato" propio de una sociedad de masas. Que esto todavía sea derecho de contratos depende de si éste ya se ha convertido en una clase nominal o no.

\section{II.8. Retribución y abolicionismo penal}

El derecho penal retributivo presupone un contexto político en el cual sujetos vinculados por normas legítimas se reconocen como personas recíprocamente. Esta precondición (política) de la responsabilidad penal aparece descrita por Duff como la necesidad de que el destinatario del reproche pueda escuchar la voz del derecho en que se formula el reproche como una voz en la cual él pueda hablar en primera persona ${ }^{253}$. Y no hay garantía meta-política alguna para que ese contexto sea necesariamente el caso. Fuera del contexto político en que es practicable la justicia retributiva, que es la única función que puede desempeñar un derecho penal funcionalmente adecuado, no hay espacio para éste.

A este respecto, es altamente significativa la reconstrucción que el otrora retribucionista Jeffrie Murphy hiciera de la visión de la práctica punitiva atribuible ni más ni menos que a Marx ${ }^{254}$. En lo fundamental, mirada la práctica punitiva desde un punto de vista susceptible de ser calificado de marxista (o al menos marxiano), la retribución aparecería como la única justificación aceptable de la punición, pues sólo la pena retributiva expresa reco-

${ }^{253}$ Duff, R.A.: "Law, Language and Community: Some Preconditions of Criminal Liability”, 1998, pp. 204-206.

${ }^{254}$ Murphy, Jeffrie: “Marxism and Retribution”, 1979, pp. 93-115. 
nocimiento de un agente; en sociedades definidas por el hecho de la alienación, sin embargo, el retribucionismo sólo prestaría una contribución reaccionaria a la validación del statu $q u o^{255}$. La objeción marxista, entonces, a diferencia de las objeciones tradicionalmente provenientes del abolicionismo, no apuntaría a una pretendida incorrección moral de la justificación de la pena retributiva, sino a la falsedad empírica de sus presupuestos fácticos; más precisamente, a la falsedad del presupuesto de una sociedad en la cual es efectivamente practicable la retribución. Siendo falso este presupuesto, el retribucionismo adolecería de un déficit de ajuste entre teoría y praxis, favoreciendo la consolidación de una falsa conciencia ${ }^{256}$. Mientras la justificación de la pena retributiva presupondría algo así como un "club de caballeros”, esto es, una comunidad articulada por valores y reglas compartidos, las sociedades capitalistas sólo conocerían la delincuencia como un fenómeno de clases, donde no hay expectativa de reciprocidad posible ${ }^{257}$. Una lectura marxista (o siquiera marxiana) de la teoría de la retribución, por ende, entendería que la primera exigencia que una teoría tal impone es la satisfacción de las condiciones materiales que hacen posible la retribución. Según Murphy, la paradoja está en que, de satisfacerse tales condiciones, probablemente habría muchos menos delitos que reprochar ${ }^{258}$.

Tan interesante como este esbozo de una reconstrucción cuasi-marxista de la práctica punitiva, es el distanciamiento de la misma emprendido posteriormente por el propio Murphy, que coincide con su distanciamiento respecto de su propia teoría retribucionista de la pena. Ofreciendo una respuesta preliminar a la pregunta acerca de por qué ha de haber derecho penal y no más bien nada, el Murphy neoliberal sugiere que la primera cuestión a establecer se refiere a la existencia misma del Estado, que podría ser visto como "una organización que podemos contratar para que haga un cierto trabajo por nosotros", trabajo que vendría a ser nuestra protección frente a amenazas externas e internas por medios que sólo interfieran con nuestras libertades en la medida en que ello sea estrictamente necesario para el éxito de ese trabajo ${ }^{259}$.

En su reconsideración crítica de la teoría retribucionista, por ende, Murphy mantiene que si reconocemos que la preocupación primaria al concurrir al contrato social ciertamente no estará referida a cómo lidiar con personas que ya han violado nuestros derechos, sino a cómo impedir que

255 Ibídem, p. 95.

${ }^{256}$ Ibídem, pp. 103-104.

${ }^{257}$ Ibídem, p. 107.

${ }^{258}$ Ibídem, p. 110.

${ }^{259}$ Murphy, Jeffrie: “Why Have Criminal Law at All?”, 1992, p. 9. 
esto ocurra, lo que entonces se plantea es la tensión que necesariamente se da entre una teoría retribucionista de la pena y una teoría liberal de la justicia política ${ }^{260}$. Si, en la senda de Rawls, se asume que los sujetos (idealizados) que llegan a la posición original para deliberar acerca de los principios básicos de justicia sobre los cuales han de organizarse las instituciones sociales fundamentales, son sujetos auto-interesados (aunque cegados por el velo de ignorancia que impide que tomen partido por un principio u otro atendiendo a cuál será más conveniente según la posición relativa que ocupen en la sociedad a constituirse), sería razonable suponer que los principios adoptados favorecerían instituciones orientadas a la prevención y no a la retribución de delitos, pudiendo suponerse además que la exigencia de culpabilidad como condición de la imposición de una pena primariamente preventiva se entendería como una exigencia independiente acerca de la distribución justa de la carga correlativa a la realización de la prevención ${ }^{261}$. El resultado sería algo bastante parecido a una teoría mixta como la de Hart o de Roxin, que parte del rechazo de que la realización de la justicia retributiva pueda ser la función de la práctica punitiva.

El Murphy neoliberal hace referencia a "Marxism and Retribution” como el producto de un sí mismo anterior por el cual ahora siente bastante poca afinidad ${ }^{262}$. Esto muestra grandeza en Murphy, el segundo, porque conlleva el reconocimiento de que quien uno es no es independiente de lo que uno hace y piensa ${ }^{263}$. En lo que aquí interesa, no puede dejar de considerarse que el Murphy anterior, al indagar en la objeción marxista de la falsedad empírica de los presupuestos de la teoría retribucionista, ponía en cuestión la corrección del punto de partida de la teoría contractualista de la justicia liberal, fuertemente vinculado al modelo del rational choice, que

${ }^{260}$ Murphy, Jeffrie: "Retributivism, Moral Education, and The Liberal State”, 1992, p. 24.

${ }^{261}$ Esta supuesta incompatibilidad entre una fundamentación retributiva de la pena y una teoría liberal de la justicia no se encuentra exenta de controversia. Al respecto, véase Scheffler, Samuel: "Justice and Desert in Liberal Theory”, 2000, pp. 965 ss., donde se defiende una interpretación de la teoría de la justicia de Rawls de acuerdo con la cual habría ella reconocería una asimetría entre justicia distributiva y justicia retributiva frente a la relación entre justicia y merecimiento. Mientras que una teoría liberal de la justicia no puede aceptar una apelación a una noción pre-institucional de merecimiento para resolver cuestiones de distribución justa, ello no regiría tratándose de cuestiones de justicia retributiva.

${ }^{262}$ Murphy, Jeffrie: Retribution Reconsidered, 1992, p. ix, lamentando que se trate de su artículo más divulgado y reconocido.

${ }^{263}$ Bastaría con preguntarle a Wittgenstein, que en las Investigaciones Filosóficas se refería en tercera persona al autor del Tractatus Logico-Philosophicus (Wittgenstein, Ludwig: Philosophische Untersuchungen, 1984, § 23). 
descansa en la asunción del auto-interés como motivación determinante ${ }^{264}$. Lo que ese modelo supone es la adecuación de la adopción de una matriz de racionalidad estratégica para la articulación del escenario en el cual han de establecerse los arreglos fundamentales sobre la base de los cuales ha de organizarse la vida en común. Cuál sea la relación de prioridad entre una función retributiva y una función preventiva de la pena, es una pregunta que depende de cuál sea la matriz de racionalidad sobre la cual deban construirse nuestros arreglos institucionales fundamentales.

Ante la constatación marxista de que el derecho penal (legítimo) es impracticable en sociedades de clases, la irrupción del abolicionismo parece seguirse de suyo. Está lejos de ser una casualidad que la izquierda política haya abrazado tantas veces esta bandera ${ }^{265}$. El abolicionismo penal es una de las evidencias más inequívocas de la derrota de la izquierda política: si nuestras sociedades hacen imposible un derecho penal legítimo, prescindamos del derecho penal. El compromiso con un abolicionismo penal más o menos explícito, que en sus versiones más tímidas se esconde bajo alguna forma de prevencionismo escéptico, asegura un terreno fértil para el desarrollo de un modelo de práctica punitiva que reproduce, en términos suficientemente plásticos, la estructura de una sociedad alienada: el modelo del derecho penal del enemigo, cuya nota distintiva es la proposición explícita de que el derecho penal es un derecho de intervención estratégica sobre una clase de individuos, precisamente, aquellos que aparecen como enemigos. A este respecto, es sumamente ilustrativa la sugerencia de Kenny en cuanto a la posibilidad de considerar a la clase de individuos "delincuentes" como una minoría. Pues lo distintivo de esta minoría sería que ella se corresponde con una clase respecto de la cual, por definición, la sociedad respectiva desearía que ella no tuviera miembros ${ }^{266}$. Lo que aquí importa es que la ideología abolicionista contribuye de este modo a afianzar la imposibilidad política de la justicia retributiva, favoreciendo la transformación del derecho penal en una categoría nominal. Como categoría nominal, la extensión de la expresión "derecho penal" queda a merced de una definición convencional, de modo tal que puede, por ejemplo, hablarse de una "pena" de presidio perpetuo para designar aquello que, funcionalmente, es sólo una medida de seguridad impuesta sobre un individuo definido como peligroso, o sea, como enemigo.

${ }^{264}$ Murphy, Jeffrie: “Marxism and Retribution”, 1979, pp. 106-107.

${ }^{265}$ Esto no supone desconocer que, sobre todo en las últimas décadas, la izquierda política también se ha inclinado a favorecer un modelo expansivo de ejercicio de la potestad punitiva. Al respecto, Silva Sánchez, Jesús: La Expansión del Derecho Penal, 1999, pp. 46-55. Esto puede contar, ciertamente, como indicio de esa derrota política.

${ }^{266}$ Kenny, Anthony: Freewill and Responsibility, 1978, p. 75-76. 
Lo anterior sugiere que la teoría de la justificación de la pena es un capítulo, y uno crucial, de cualquier teoría de la justicia política. Y es en este contexto en que debe situarse la pregunta por el fundamento correcto de la pena estatal. La tesis aquí defendida sostiene que la fundamentación retributiva de la práctica punitiva es la correcta porque ella produce, interpretativamente, la mejor concepción de esa práctica: a saber, una práctica cuyo sentido descansa en la expresión de reproche merecido entre sujetos que se reconocen como agentes morales iguales. La ironía está en que esta concepción de la función de la pena produce un derecho penal cuya estructura, mucho más que ajustarse a la que se figuraba Kant, parece seguir al pie de la letra cada uno de los puntos de reforma reclamados por Beccaria, exponente paradigmático del utilitarismo penal ilustrado. Por eso es tan sugestiva la observación de Höffe en cuanto a que la concepción retributiva de la pena del Kant posterior al giro crítico, mirada en términos de principio, representa la culminación de la ilustración jurídico-penal ${ }^{267}$. Mas no hay razón alguna para pensar que, así entendido, necesariamente ha de haber derecho penal. El auténtico problema no es, como creen los abolicionistas, que actualmente tengamos demasiado derecho penal; es, más bien, que eventualmente no tengamos derecho penal, y más aún, que quizá no podamos tenerlo.

\section{BiBLIOGRAFíA}

Atria, Fernando: On Law and Legal Reasoning. Portland: Hart Publishing, 2001.

“La Hora del Derecho: Los 'Derechos Humanos' entre la Política y el Derecho”. En Estudios Públicos, 91 (2003), pp. 45 ss.

“Jurisdicción e Independencia Judicial: el Poder Judicial como Poder Nulo”. En Revista de Estudios de la Justicia, 5 (2004), pp. 119 ss.

Austin, J.L.: How to Do Things with Words. Cambridge, Mass.: Harvard University Press, 1962, 1975.

Baurmann, Michael: Zweckrationalität und Strafrecht. Opladen: Westdeutscher Verlag, 1987.

Benhabib, Seyla: “On the Philosophical Foundations of Cosmopolitan Norms”. En Tomasz Gizbert-Stunicki y Jerzy Stelmach (ed.), Law and Legal Cultures in the 21st Century. Varsovia: Oficyna, 2007, pp. 61-80.

Bieri, Peter: Das Handwerk der Freiheit. Über die Entdeckung des eigenen Willens. Frankfurt a.M.: Fischer, 2001.

Bung, Jochen: "Feindstrafrecht als Theorie der Normgeltung und der Person”. En HRRS, 2/2006, pp. 63-71.

${ }^{267}$ Höffe, Otfried: “Proto-Derecho Penal: Programa y Cuestiones de un Filósofo", 2004, p. 344. 
Cancio Meliá, Manuel: “¿`Derecho Penal del Enemigo’?”. En Günther Jakobs y Manuel Cancio Meliá, Derecho Penal del Enemigo. Madrid: Civitas, 2003, pp. 57-102.

Cholbi, Michael: “A Felon's Right to Vote”. En Law and Philosophy, 21 (2002), pp. 543 ss.

Corlett, J. Angelo: Responsibility and Punishment. Dordrecht, Boston: Kluwer, 2004.

Dahl, Robert: On Democracy. New Haven: Yale University Press, 1998, 2000.

“Procedural Democracy”. En Robert Dahl, Democracy, Liberty, and Equality. Oslo: Norwegian University Press, 1986, pp. 191-225.

Dennett, Daniel: Freedom Evolves. New York: Penguin Books, 2003.

Detmold, Michael: “Law as Practical Reason”. En Cambridge Law Journal, 48 (1989), pp. 436-471.

Duff, R.A: "Law, Language and Community: Some Preconditions of Criminal Liability".

En Oxford Journal of Legal Studies, 18 (1998), pp. 189-206.

Dworkin, Ronald: Law's Empire. Cambridge, Mass.: Harvard University Press, 1986.

Feinberg, Joel: “The Expressive Function of Punishment”. En Joel Feinberg, Doing \& Deserving. Princeton: Princeton University Press 1970, pp. 95-118.

- “Justice and Personal Desert”. En Joel Feinberg, Doing \& Deserving. Princeton: Princeton University Press 1970, pp. 55-94.

Fichte, J.G.: Fundamento del Derecho Natural. Madrid: Centro de Estudios Constitucionales, 1994.

Foucault, Michel: Vigilar y Castigar. El Nacimiento de la Prisión. Madrid: Siglo XXI, 1976, 2000.

Frankfurt, Harry: “Alternate possibilities and moral responsibility”. En Harry Frankfurt, The Importance of What We Care About. New York: Cambridge University Press, 1988, pp. 1-10.

"Freedom of the Will and the Concept of a Person”. En Harry Frankfurt, The Importance of What We Care About. New York: Cambridge University Press, 1988, pp. 11-25.

Fuller, Lon: The Morality of Law. New Haven: Yale University Press, 1964.

Gracia Martín, Luis: "Consideraciones Críticas sobre el Actualmente Denominado Derecho Penal del Enemigo”. En Revista Electrónica de Ciencia Penal y Criminología, 7 (2005).

Günther, Klaus: Der Sinn für Angemessenheit. Frankfurt a.M.: Suhrkamp, 1989. "Die symbolische-expressive Bedeutung der Strafe". En Cornelius Prittwitz, Michael Baurmann, Klaus Günther et al. (ed.), Festschrift für Klaus Lüderssen. Baden-Baden: Nomos, 2002, pp. 205 ss.

- Schuld und kommunikative Freiheit. Frankfurt a.M.: Vittorio Klostermann, 2005.

Habermas, Jürgen: Facticidad y Validez. Madrid: Trotta, 1998.

“¿Qué Significa Pragmática Universal?”. En Jürgen Habermas, Teoría de la Acción Comunicativa. Complementos y Estudios Previos. Madrid: Cátedra, 1989, pp. 299 ss.

— Teoría de la Acción Comunicativa. Madrid: Taurus, 1999.

Hart, H.L.A.: "Prolegomenon to the Principles of Punishment". En H.L.A. Hart, Punishment and Responsibility. Oxford: Clarendon Press, 1968, pp. 1 ss.

- "Legal Responsibility and Excuses". En H.L.A. Hart, Punishment and Responsibility. Oxford: Clarendon Press, 1968, pp. 28-53. 
Hegel, G.W.F.: Grundlinien der Philosophie des Rechts. Frankfurt a.M., Suhrkamp, 1970. Hirsch, Andrew von: Doing Justice. New York: Hill and Wang, 1976.

- Past or Future Crimes. New Brunswick: Rutgers University Press, 1985.

Hoerster, Norbert: “Ética Utilitarista y Generalización”. En Norbert Hoerster, Problemas de Ética Normativa. Buenos Aires: Alfa, 1975, pp. 50 ss.

Höffe, Otfried: “Proto-Derecho Penal: Programa y Cuestiones de un Filósofo”. En Albin Eser, Winfried Hassemer y Björn Burkhardt, La Ciencia del Derecho Penal ante el Nuevo Milenio. Granda, Tirant lo Blanch, 2004, pp. 327-66.

Jakobs, Günther: Strafrecht Allgemeiner Teil. Berlin: Walter de Gruyter, 1991.

— “¿Superación del Pasado mediante el Derecho Penal?”. En Anuario de Derecho Penal y Ciencias Penales, 47 (1994), pp. 137 ss.

“Crímenes del Estado-Ilegalidad en el Estado”. En Doxa, 17-18 (1995), pp. 445-67.

- "Criminalización en el Estadio Previo a la Lesión de un Bien Jurídico”. En Günther Jakobs, Estudios de Derecho Penal. Madrid: Civitas, 1997, pp. 293-324.

- Sobre la Teoría de la Pena. Bogotá: Universidad Externado de Colombia, 1998.

“Derecho Penal del Ciudadano y Derecho Penal del Enemigo". En Günther Jakobs y Manuel Cancio Meliá, Derecho Penal del Enemigo. Madrid: Civitas, 2003, pp. 19-56.

"La Autocomprensión de la Ciencia del Derecho Penal ante los Desafíos del Presente (comentario)”. En Albin Eser, Winfried Hassemer y Björn Burkhardt (ed.), La Ciencia del Derecho Penal ante el Nuevo Milenio. Valencia: Tirant lo Blanch, 2004, pp. 53-64.

- La Pena Estatal: Significado y Finalidad. Madrid: Thomson, Civitas, 2006.

Kenny, Anthony: Freewill and Responsibility. Londres: Routledge \& Kegan Paul, 1978.

Kindhäuser, Urs: Gefährdung als Straftat. Frankfurt a.M.: Vittorio Klostermann, 1989.

- "Personalität, Schuld und Vergeltung”. En Goltdammer's Archiv für Strafrecht, 1989, pp. 493-507.

- "La Fidelidad al Derecho como Categoría de la Culpabilidad”. En Revista Peruana de Doctrina y Jurisprudencia Penal, 1 (2000), pp. 171 ss.

Lesch, Heiko: La Función de la Pena. Madrid: Dykinson, 1999.

Lippke, R.L.: “The Disenfranchisement of Felons”. En Law and Philosophy, 20 (2001), pp. 553 ss.

Liszt, Franz von: Tratado de Derecho Penal. Madrid: Reus, 1999.

Mackie, John: Ethics. Inventing Right and Wrong. Middlesex: Penguin, 1977.

Mañalich, Juan Pablo: “¿La Comisión de Delitos mediante la Imputación de Delitos? Los Delitos contra el Honor bajo la Teoría de los Actos de Habla”. En Revista Peruana de Doctrina y Jurisprudencia Penal, 6 (2005), pp. 193-242

“Pena y Ciudadanía”. En Revista de Estudios de la Justicia, 6 (2005), pp. 6383.

Mele, Alfred: Autonomous Agents. From Self-Control to Autonomy. New York: Oxford University Press, 1995.

Moore, Michael S.: “Moral Reality”. En Wisconsin Law Review, 1982, pp. 1061-156. "Law as a Functional Kind". En Robert George (ed.), Natural Law Theory. Oxford: Clarendon Press, 1992, pp. 188 ss.

- Act and Crime. Oxford: Oxford University Press, 1993. 
- Placing Blame: A General Theory of the Criminal Law. Oxford: Oxford University Press, 1997.

"Victims and Retribution: A Reply to Professor Fletcher". En Buffalo Criminal Law Review, 3 (2000), pp. 66 ss.

- "Law as Justice". En Michael Moore, Objectivity in Ethics and Law.

Burlington: Ashgate, 2004, pp. 261 ss.

Mouffe, Chantal: El Retorno de lo Político. Barcelona: Paidós, 1999.

Murphy, Jeffrie: “Cruel and Unusual Punishments”. En Jeffrie Murphy, Retribution, Justice, and Therapie. Boston, Dordrecht: Kluwer, 1979, pp. 223-249.

- "Kant's Theory of Criminal Punishment”. En Jeffrie Murphy, Retribution, Justice, and Therapie. Boston, Dordrecht: Kluwer, 1979, pp. 82-92.

"Marxism and Retribution". En Jeffrie Murphy, Retribution, Justice, and

Therapie. Boston, Dordrecht: Kluwert, 1979, pp. 93-115.

- Retribution Reconsidered. Boston, Dordrecht: Kluwert, 1992.

- "Why Have Criminal Law at All?”. En Jeffrie Murphy, Retribution

Reconsidered. Boston, Dordrecht: Kluwert, 1992, pp. 1 ss.

- "Retributivism, Moral Education, and The Liberal State". En Jeffrie Murphy,

Retribution Reconsidered. Boston, Dordrecht: Kluwert, 1992, pp. 15 ss.

- "Getting Even: The Role of The Victim”. En Jeffrie Murphy, Retribution Reconsidered. Boston, Dordrecht: Kluwert, 1992, pp. 61 ss.

Müssig, Bernd: "Derecho Penal del Enemigo: Concepto Fatídico y Presagio. Algunas Tesis”. En Manuel Cancio Meliá y Carlos Gómez-Jara, Derecho Penal del Enemigo. Montevideo, Buenos Aires: BdF, 2006, Vol. 2, pp. 371-390.

Nedelsky, Jennifer: “Communities of Judgment and Human Rights”. En Theoretical Inquiries in Law, 1 (2000).

Nozick, Robert: Philosophical Explanations. Cambridge, Mass.: Harvard University Press, 1981.

Pauen, Michael: Illusion Freiheit? Mögliche und unmögliche Konsequenzen der Hirnforschung. Frankfurt a.M.: Fischer, 2004.

Pawlik, Michael: Person, Subjekt, Bürger. Zur Legitimation von Strafe. Berlin: Duncker \& Humblot, 2004.

Pillsbury, Samuel: “Emotional Justice: Moralizing the Passions of Criminal Punishment”. En Cornell Law Review, 74 (1989), pp. 655 ss.

Rawls, John: A Theory of Justice. Oxford: Oxford University Press, 1971. “Two Concepts of Rules”. En The Philosophical Review, 64 (1955), pp. 3-32.

Robinson, Paul: "Why Does the Criminal Law Care What the Layperson Thinks is Just: Coercive versus Normative Crime Control”. En Virginia Law Review, 86 (2000), pp. 1839 ss.

"Fair Notice and Fair Adjudication: Two Kinds of Legality". En University of Pennsylvania Law Review, 154 (2005), pp. 335 ss.

Robinson, Paul y John Darley: “The Utility of Desert”. En Northwestern University Law Review, 91 (1997), pp. 453 ss.

Roxin, Claus: “Sentido y Límites de la Pena Estatal”. En Claus Roxin, Problemas Básicos del Derecho Penal. Madrid: Reus, 1976, pp. 11-36.

“Concepción Bilateral y Unilateral del Principio de Culpabilidad”. En Claus Roxin, Culpabilidad y Prevención en Derecho Penal. Madrid: Reus, 1981, pp. 187-200. 
Scheffler, Samuel: “Justice and Desert in Liberal Theory”. En California Law Review, 88 (2000), pp. 965 ss.

Schröder, Jürgen: Einführung in die Philosophie des Geistes. Frankfurt a.M.: Suhrkamp, 2004.

Searle, John: Speech Acts. Cambridge: Cambridge University Press, 1969.

“A Taxonomy of Illocutionary Acts”. En John Searle, Expression and Meaning. Cambridge: Cambridge University Press, 1979, pp. 1 ss.

The Construction of the Social Reality. London: The Penguin Press, 1995. Mind. A Brief Introduction. New York: Oxford University Press, 2004.

Silva Sánchez, Jesús: La Expansión del Derecho Penal. Madrid: Civitas, 1999. "Del Derecho Abstracto al Derecho 'Real'”. En InDret, 4 (2006), pp. 377383.

Smart, J.J.C.: “An Outline of a System of Utilitarian Ethics”. En J.J.C. Smart y Bernard Williams, Utilitarianism: For \& Against. Cambridge: Cambridge University Press, 1973, pp. 3-74.

Strawson, P.S.: Libertad y Resentimiento. Barcelona: Piados, 1995.

Tunick, Mark: Punishment. Theory and Practice. Berkeley: University of California Press, 1992.

Waldron, Jeremy: “Lex Talionis”. En Arizona Law Review, 34 (1992), pp. 25 ss.

Walzer, Michael: Obligations: Essays on Disobedience, War, and Citizenship. Cambridge: Harvard University Press, 1970.

Las Esferas de la Justicia. México: Fondo de Cultura Económica, 1993.

Widerker, David y Michael MacKenna: Moral Responsibility and Alternative Possibilities. Aldershot: Ashgate, 2003.

Williams, Bernard: “A Critique of Utilitarianism”. En J.J.C. Smart y Bernard Williams, Utilitarianism: For \& Against. Cambridge: Cambridge University Press, 1973, pp. $77-150$.

Wittgenstein, Ludwig: Philosophische Untersuchungen. Frankfurt a.M.: Suhrkamp, 1984. 